\title{
Are plants used for skin care in South Africa fully explored?
}

\author{
Namrita Lall*, Navneet Kishore
}

Department of Plant Science, Plant Science Complex, University of Pretoria, Pretoria-0002, South Africa

Corresponding Author: Prof. Namrita Lall

Department of Plant Science,

Plant Sciences Complex, University of Pretoria,

Pretoria-0002, South Africa

E-mail: namrita.lall@up.ac.za

Phone: 012-420-2524; Fax: +27-12-420-6668

Co-author: Dr. Navneet Kishore

Department of Plant Science,

Plant Sciences Complex, University of Pretoria,

Pretoria-0002, South Africa

E-mail: kishore.navneet6@gmail.com

Phone: +27-12-420-6995

\section{Graphical Abstract}

Scientific validation of South African medicinal plants used traditionally for skin care and their pharmacological properties associated with treating skin conditions.

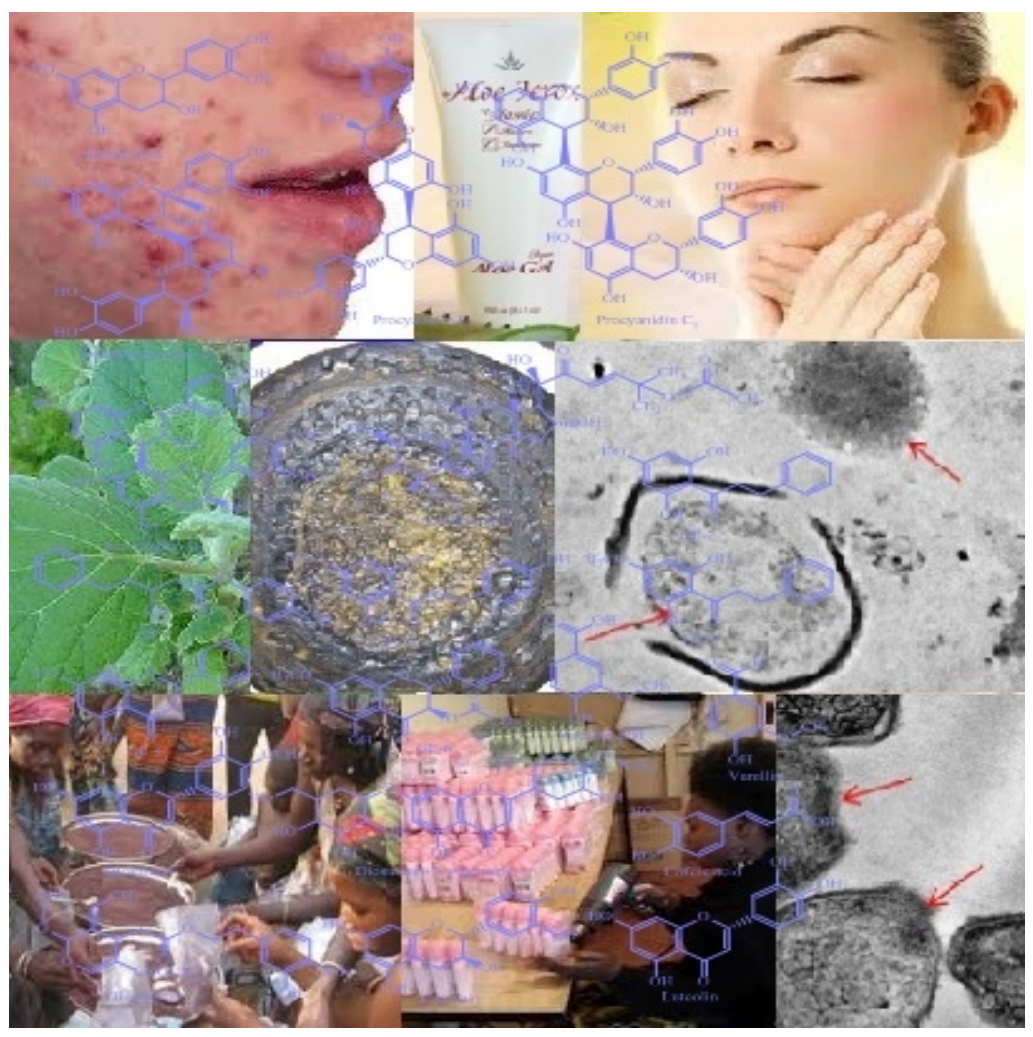




\section{Contents}

1. Introduction

2. Plant as natural source for skin care

3. Abundance of active constituents is the backbone of phyto-derived products

4. Plants grown in South Africa, a potential source for new preparation with beneficial effects on the skin

4.1. Aloe ferox Mill.

4.2. Aspalathus linearis (Burm.f.) R. Dahlgren

4.3. Calodendrum capense (L.f.) Thunb.

4.4. Citrullus lanatus (Thunb.)

4.5. Elaeis guineensis Jacq

4.6. Eriocephalus africanus L.

4.7. Eriocephalus punctulatus L.

4.8. Greyia flanaganii Bolus

4.9. Olea europaea L. subsp. africana (Mill.) P.S.Green

4.10. Pelargonium graveolens L'Her.

4.11. Schinziophyton rautanenii Schinz

4.12. Sclerocarya birrea Sond.

4.13. Sesamum indicum $\mathrm{L}$.

4.14. Sideroxylon inerme L.

4.15. Ximenia americana L.

5. Activities attributed to skin-care ethnobotanicals

5.1. Antioxidant activity

5.2. Anti-inflammatory activity

5.3. Anti-tyrosinase activity

5.4. Wound treatment

6. Scientifically investigated plant species: further exploration needed 
7. Scientifically unexplored plant species: specific research needs

8. Conclusion

Acknowledgements

References

\section{Introduction}

Skin is the largest organ in the body which protects the internal environment from the external one and adds to our beauty too. Beauty is a quality that gives pleasure to the senses, which is desired by many humans. In general terms skin diseases account for approximately $34 \%$ of all the diseases encountered worldwide (Abbasi et al., 2010). They affect people of all ages and constitute a major concern for medical consultation. Skin diseases currently exist as a major health burden in both developed and undeveloped countries. According to the World Health Organization (WHO), burns have also been a serious public health problem due to the global increase in burn mortality rates. In South Africa, over 19,500 fire-related deaths are reported annually and they rank among the 15 leading causes of death among youngsters (529 years). However, mortality rate for skin diseases is relatively low, often persistent and are difficult to treat (WHO 2012). There are many different ways to protect our skin. The usage of natural ingredients for skin care is very popular today. Medicinal plants have been found to play a major role in the treatment of various skin disorders and these species have been used in many countries around the world where they contribute significantly towards the health care for skin (De Wet et al., 2013). Moreover, the extensive use of medicinal plants to treat dermatological conditions in traditional system of whole southern Africa has been recently reported (Mabona et al., 2013).

The search for natural remedies for skin care is on-going worldwide. A review by Vermaak et al. (2011) focused on the importance of seeds oil from six species used in the preparation of cosmetics, also mentioned the traditional and other medicinal usage of seed 
oils. An article by Mabona et al. (2013) focussed on the dermatological applications of about 47 southern African medicinal plants. The authors had mainly mentioned the antimicrobial effects of plants against skin pathogens. Chen et al. (2012) summarised very systematically the medicinal and cosmetic relevance of the Aloe ferox, a fully explored plant of South Africa which is also used in cosmetic herbal formulations. A document from Brendler and Denzil (2011) unpublished work, provided a list of African cosmetic species and their usage. Reports by other researchers such as Mukul et al. (2011); Gupta et al. (2011); Preetha and Karthika (2009); Gediya et al. (2009); Jain et al. (2010); Shivanand et al. (2009), focussed on the significance of Indian herbs and spices used in maintaining and enhancing human beauty as well as popularity of these herbs in cosmetics. Chaudhari et al. (2011) reviewed common types of plants used for skin care and concluded that the oxidative stress is one of the major mechanisms for skin aging and dermatological conditions.

These publications do not cover relevant significant scientific information regarding South African plants used for skin care. The need for review of the plants species grown in South Africa should focus on gaps in our understanding of traditional uses and in-vitro studies such as, pharmacological studies, toxicity profiling, pre-clinical and clinical trials. Previous review reported by Chen et al. (2012); Van Wyk and Gericke (2000) were directed at phytochemical aspects and few pharmacological activities of the species. Hence, an attempt was made to update the complete information on traditional uses, phytochemical aspects, toxicity and pharmacological activities of the species, which can aid for future research to be taken on the respective species by synthetic chemists, phytochemists, pharmacologists, clinicians, scientists and toxicologists etc. The review highlighted the traditional formulations made from the species for skin care (Table 1), in addition to this, different biological activities and toxicological studies have been reported on various extracts of different plant parts (Table 2).

There is growing interest in the health benefits of plants grown in South Africa with regard to skin care. In line with this, there is an increasing numbers of published articles 
claiming that plant or plant derived actives may function as candidate for skin care. However, it is unclear which plant extract/active can work effectively. Therefore, to test this all available literature were reviewed with an intention of capturing what biological and/or phytochemical studies have been performed on those extracts. The present review focused on the ethnopharmacological aspects of 117 plant species used traditionally in South Africa for skin care belonging to 57 families and 101 genera, which are applied topically or taken orally in the traditional healing system of the South African population. Disorders treated, include abscesses, acne, burns, boils, incisions, ringworm, rashes, shingles, sores, wounds and warts. But such knowledge of medicinal plants is limited to specific localities in rural area. In other words, only a few people from local areas have information on the use of these medicinal plants. These species are still not fully investigated scientifically and a few are completely unexplored.

The main aims of the present review are as follows:

- Which species are used traditionally for skin care by people of South Africa?

- Which species have been explored scientifically? Either for the identification of bioactive compounds or for pharmacological applications

- What types of activities are associated with the species which have already been studied scientifically?

- How many species are still unexplored scientifically for skin care?

- A critical assessment of the existing information available in the literature on the pharmacological activity and traditional usage of plants grown in South Africa for skin care

- Based on existing knowledge about the species, what are the perspectives and directions for future research and potential applications 


\section{Plants as natural source for skin care}

There has been a very long history in human civilization of the usage of natural ingredients; such as herbs, roots, essential oils and flowers for skin care. Egyptians, were the first to use the whipped ostrich eggs, olive oil, resin mixed with milk for the treatment of variety of skin conditions from ancient time. Nowadays, the most common examples of natural skin care ingredients include palm oil, sesame seed oil, linseed, jojoba oil, sandalwood, witch hazel, tea tree oil, chamomile and many more (Pandey et al., 2010). The use of bioactive extracts or phytochemicals from a variety of botanicals accomplish two functions; firstly they serve as cosmetics for the care of the body and secondly the botanical ingredients influence the biological functions of the skin, providing the nutrients necessary for a healthy skin (Dureja et al., 2005). Generally botanical products are a rich source of vitamins, antioxidants, various oils, essential oils, hydrocolloids, proteins, terpenoids and other bioactive molecules. The use of herbal medicines by communities of African descent is estimated to be $75 \%$ by the World Health Organization (Dubey et al., 2004).

\section{Abundance of active constituents are the backbone of phyto-derived products}

Plant extracts mainly added to herbal preparations for their topical use, are associated with several antimicrobial properties including anti-inflammatory and antioxidant properties. These antioxidant botanicals are generally classified into three categories depending upon the nature of their constituents, namely carotenoids, flavonoids and polyphenols. Carotenoids are structurally related to vitamin $\mathrm{A}$ and constitute various retinols like retinoic acid. The flavonoids, in addition to their antioxidant action also impart UV protection and have metal chelating properties (Glaser, 2004). However, whole herbal extracts consist of numerous compounds that together, provide better effects on the skin with regard to antioxidant, antiinflammatory, emollient, melanin-inhibiting, antimutagenic and anti-aging properties.

Apart from the above, herbal extracts have also been shown to exhibit antifungal and antileishmanial properties. An ointment made from bark of Calodendrum capense (L.f.) Thunb. (Cape Chestnut) and a lotion made from leaves of Warburgia salutaris (Bertol. f.) 
Chiov. (Pepper-bark tree) are used to treat fungal infections. Several other species such as Croton sylvaticus Hochst. (Woodland croton), Terminalia sericea Burch. ex DC. (Silver terminalia), Withania somnifera L. (Winter cherry) and Zantedeschia aethiopica Spreng. (White arum lily) exhibited antifungal activities (Fernandes et al., 2008; Mokoka et al., 2010). All these have attracted major attention of research scientists and clinicians because of the increasing incidence of fungal infections; leading to skin disorders. Likewise, fatty acids have been shown to have beneficial effects when applied onto the skin. In addition, the oils are also used as a carrier for other active ingredients. The presence of certain fatty acids has also proved to enhance skin permeation of co-administered molecules (Vermaak et al., 2011). Additionally, flavonoids, in the form of crude plant extracts, have long been utilised for their anti-inflammatory capacity in the cosmetic industry (Kim et al., 2004). There are various types of phyto-constituents that play a significant role in the improvement of skin smoothness and for protection from other skin problems.

However, phenolics rich plants species are candidates used for prevention of harmful effects of UV radiation on the skin. Also, the high concentration of plant peptides protects the peptide bonds of the skin proteins. The proteins, absorbing lipids, and nucleotides are also used as the skin's natural sun blockers (Anitha, 2012). There are a lot of different types of sunscreen products like oils, gels, creams, lotions which are made from mixture of different species, which provide adequate protection from harmful UV rays. Seed oils are ideally suited to satisfy this need due to the presence of fatty acids which have been shown to have beneficial effects when applied onto the skin (Vermaak et al., 2011; Welford et al., 2008). Sesame oil is one of the most efficient oils with $30 \%$ resistance of UV rays, while other oils resist about $20 \%$. Most of the taxa listed in table 1 are not fully explored specially with regard to the identification of bioactive compounds, a few are totally unexplored. Phytochemical investigation of these plants is still warranted. 


\section{Plants grown in South Africa, a potential source for new preparation with beneficial}

\section{effects on the skin}

The majority of people in Africa use plant based traditional medicines for their health care. Nowadays in rural areas of South Africa 'Natural cosmetic products, are more frequently bought from herbal shops, but in a few cases they are still prepared at home, especially those for burns or skin inflammation. The use of medicinal plants to treat dermatological conditions has been observed in whole southern Africa as traditional medicine to treat skin diseases recently (Mabona et al., 2013). It is of great interest to know whether plant formulations used for skin care traditionally in South Africa may be part of modern formulations. South Africa, which has a history of traditional healing, has around 30,000 flowering plant species (Louw et al., 2002; Van Wyk and Viljoen, 2011), and accounts for almost $10 \%$ of the world's higher plant species (Van Wyk and Gericke, 2000). Therefore, significant research and development opportunities exist to discover the novel and useful biological with regard to skin care potential (Street and Prinsloo, 2013).

The oil of some popular South African plants viz. African oil palm (Elaeis guineensis Jacq), Baobab (Adansonia digitata L.), Cape Mahogany (Trichilia emetica Vahl.), False Sandalwood (Ximenia Americana L.), Manketti (Schinziophyton rautanenii Schinz), Marula (Sclerocarya birrea Sond.), Sesame (Sesamum indicum L.) and Wild Watermelon (Citrullus lanatus Thunb.) have been frequently used in cosmetic formulations due to moisturizerising effect. In addition to this, there are other popular South African plants such as Bitter Aloe (Aloe ferox Mill.), Rooibos tea (Aspalathus linearis (Burm.f.) R.Dahlgren), Cape Chestnut (Calodendrum capense (L.f.) Thunb.), Honeybush tea (Cyclopia intermedia E. Mey.), White milkwood (Sideroxylon inerme L.) and Blue mountain sage (Salvia stenophylla Burch. ex Benth) which are regularly used in various skin creams for anti-aging, anti-acne, anti-wrinkle and for skin-hyperpigmentation problems. An ointment made from cape chestnut is used for the treating those who suffers from psoriasis, skin cracking, sagging and eczema. 
It continues a long-standing healthcare system intimately linked to traditional health care system which serves as the primary source of healthcare in South Africa (Makunga et al., 2004) including skin disorders (Van Wyk et al., 2008). Research on traditional species, like Adansonia digitata L. (Baobab), Aspalathus linearis Burm. f. (Rooibos tea), Elaeis guineensis Jacq (African oil palm), Kigelia africana (Lam.) Benth. (Sausage tree), Trichilia emetica Vahl. (Natal Mahogany), Schinziophyton rautanenii Schinz (Mongongo tree), Sclerocarya birrea Sond. (Marula), Warburgia salutaris (Bertol. f.) Chiov. (Pepper-bark tree) using multi-dimensional approaches originating from national and international, focused on South Africa has led to the development of several plant-derived products for skin care (Kiken and Cohen, 2002). Scientific evidence demonstrated that species such as Aloe ferox Mill. (Bitter Aloe), Aspalathus linearis Burm. f. (Rooibos tea), Calendula officinalis L. (Pot marigold), Crocus sativus L. (Saffron), Kigelia africana (Lam.) Benth. (Sausage tree), Eriocephalus punctulatus L. (Wild rosemary), Greyia flanaganii Bolus (Kei bottlebrush), Sideroxylon inerme L. (White milkwood) etc. possess significant biological properties and can actively restore, heal and protect the skin (Chen et al., 2012; Marnewick et al., 2005).

A detailed description of the traditional usage, relevant pharmacological activities and phytochemical constituents of a few most popular and researched taxa of South Africa are as follows:

\subsection{Aloe ferox Mill.}

Aloe ferox commonly known as the bitter aloe or Cape aloe is a variable species indigenous to the Cape coastal region of South Africa (Van Wyk et al., 2009). Traditionally the leaves and roots are applied topically or taken internally to treat dermatitis, acne and other skin diseases such as skin cancer, burns and psoriasis (Loots et al., 2007). It is also used in small doses as a "blood purifier" in cases of acne and recently the inner leaf parenchyma has become popular ingredient in skin care products. Aloe gel can be added to various cosmetic products such as cleansers, moisturisers, shampoos, suntan lotions, and sunburn screens. Aloesin showed promising activity as a pigmentation-altering agent for cosmetic or 
therapeutic applications (Yagi and Takeo, 2003). The phytochemical literature survey of $A$. ferox revealed that it contains chromones, anthraquinones, antrhrones, anthrone- $C$-glycosides and other phenolic compounds (Chen et al., 2012).

\subsection{Aspalathus linearis (Burm.f.) R. Dahlgren}

Aspalathus linearis (Rooibos tea) is a herbal tea that grows in Cape Province. The tea has been said to have many functions for example, it helps to increase appetite, improve bowel movement and control mental condition (Nakano et al., 1997). During pregnancy African women takes rooibos to relieve heartburn, as an iron supplement, for colic relief for infants etc. Rooibos is well known for its antioxidant activity which also relates to its hepatoprotective properties (Breiter et al., 2011). Rooibos contains unique phenolic compounds, namely, aspalathin, a dihydrochalcone $C$-glucoside and aspalalinin, a cyclic dihydrochalcone along with many other compounds, also abundant in flavonoids particularly, aspalathin, isoorientin, nothofagin, quercetin and isoquercitrin etc. (Kazuno et al., 2005; Street and Prinsloo, 2013).

\subsection{Calodendrum capense (L.f.) Thunb.}

The plant Calodendrum precisely devoted as a beautiful tree, also known as Cape Chestnut tree is a member of the family Rutaceae (Leistner, 2000). Traditionally the bark is used as an ingredient of skin ointment (Van Wyk and Gericke, 2000). Seeds are crushed and boiled to obtain oil that is suitable for making soap. Seeds oil is extracted from Cape Chestnut also known as Yangu oil (Ramoroka and Mapunya, 2006). This oil has natural UV protection, high content of fatty acids (especially linoleic) and antioxidants. It is very popular for African hair and skin care. Main fatty acids present in oil are palmitic, oleic, linoleic and stearic acid. The leaves and bark also used as a facial mask, in soap preparations and for skinhyperpigmentation problem (Mapunya et al., 2012).

\subsection{Citrullus lanatus Thunb.}

Citrullus lanatus (Cucurbitaceae) commonly called water melon is widely distributed, but naturally occurs in South Africa, Namibia, Botswana, Zimbabwe, Mozambique, Zambia 
and Malawi (Lucky et al., 2012). It is an excellent source of vitamin A, B and C. Pink watermelon is also a source of the arginine, carotenoids, lycopenes, carbohydrate, sodium, magnesium, potassium and water. Traditionally Citrullus lanatus is in use as energy source, act as antioxidant and is used to treat enlarged liver and jaundice (Yativ et al., 2010). The seed contains $20-40 \%$ oil and fatty oil in the seed (Hassan et al., 2011), the main fatty acids are linoleic, oleic, palmitic and stearic acids. Citrullus seed oil is also known to contain traces of linolenic, myristic, and lauric acids and both the oil and the fatty acid contents are stable after 6 months in storage (Jarret and Levy, 2012). Due to the presence of fatty acids and carotenoids it is also used for making soap. Face masks made from the fruit are used as a cosmetic for delicate skins.

\subsection{Elaeis guineensis Jacq.}

Elaeis guineensis (Oil palm) is a perennial plant and is measured to be the most productive oil crop with 42.41 million metric tonnes production in 2008 to 2009 contributing to $36 \%$ of total world oil production (Tahir et al., 2012). In traditional medicine, the leaf of the plant is squeezed and the juice thus obtained is placed on wounds to promote healing (Sasidharan et al., 2012). The leaf extract and juice from young petioles are applied to fresh wounds. The fruit mesocarp oil and palm kernel oil are administered as a poison antidote and used externally with several other herbs as a lotion to treat skin diseases. Major fatty acids are linoleic, palmitic, linolenic acids with trace amounts of oleic, stearic, arachidic, myristic, lauric, palmitoleic and margaric acids. The fruit husk is used in the preparation of soaps which is used to treat skin infections and is also used in cosmetics and personal care products, these palm oil ingredients are used in the formulation of skin care and makeup products (Sasidharan et al., 2010).

\subsection{Eriocephalus africanus $\mathrm{L}$.}

Eriocephalus africanus (Asteraceae) is a common, fragrant woody shrub that occurs in specific localities in the Western Cape and Karoo regions of South Africa. It is also called as Cape snowbush or Rosemary. The infusions of leaves are used in treating inflammation 
and other dermal complications (Philander, 2011). It has been reported that rosemary stimulated and improved circulation throughout the body; it increased the blood supply to the skin, which is thought to help restore a youthful glow. It has been also stated that Rosemary promotes hair growth (Njenga et al., 2005). The rosemary oil is therefore completely natural and used for aromatherapy, cosmetic and perfume.

\subsection{Eriocephalus punctulatus L.}

Eriocephalus punctulatus (Asteraceae), also known as the Cape chamomile grows on the north-east slopes of the Drakensberge mountain range in the province free state of South Africa (Philander, 2011). Nowadays, commercial Cape chamomile oil due to its pleasant odour, is being used as a fragrance in cosmetics and toiletries; it is increasingly employed in aromatherapy (Kamatou et al., 2011). The blue colour of the commercial Cape chamomile oil is associated by the presence of azulene derivatives in the oil, which are formed by the decomposition of proazulenes during steam distillation. From literature reports very few components have been identified in Cape chamomile oil. 2-Methylbutyl isobutyrate, 2methylpropyl isobutyrate, $p$-cymene, $\alpha$-pinene, 2-methylbutyl isovalerate and 3-methylbutyl isobutyrate were found to be the main components.

\subsection{Greyia flanaganii Bolus}

Greyia flanaganii is an evergreen, rare endemic southern African plant species, one of three closely related species of the family Greyiaceae. In 1998 it was the Tree of the Year. This plant is very frost tolerant. It remains evergreen even in areas exposed to frost in winter (Steyn et al., 1987). It has been reported that the ethanol leaf extract exhibited significant anti-tyrosinase activity with the fifty percent inhibitory concentration $\left(\mathrm{IC}_{50}\right)$ of $32.62 \mu \mathrm{g} / \mathrm{ml}$ when tyrosine was used as a substrate. The total extract also showed significant inhibition of melanin production at $6.25 \mu \mathrm{g} / \mathrm{ml}$ and low levels of cytotoxicity with $\mathrm{IC}_{50}<400 \mu \mathrm{g} / \mathrm{ml}$. Isolated compounds showed good radical scavenging activity and low toxicity of the cells with reduction of melanin content of the cells (Mapunya et al., 2011). 
The compounds isolated from the plant were (3S)-4-hydroxyphenethyl 3-hydroxy-5phenylpentanoate, 2',4',6'-trihydroxy-dihydrochalcone, 2',6',4-trihydroxy-4'-methoxydihydrochalcone, 2',6'-dihydroxy-4'-methoxydihydrochalcone, 5,7- dihydroxyflavanone [(2S)pinocembrin], 2',6'-dihydroxy-4',4-dimethoxy dihydrochalcone and (2R,3R)-3,5,7trihydroxy-3-O-acetylflavanone. Compound 2',4',6'-trihydroxydihydrochalcone exhibited significant antityrosinase activity exhibiting the fifty per cent inhibitory concentration of $\left(\mathrm{IC}_{50}\right) 69.15 \mu \mathrm{M}$ (Mapunya et al., 2011).

\subsection{Olea europaea L. subsp. africana (Mill.) P.S. Green}

The olive tree Olea europaea is a member of the family Oleaceae, have been widely used in folk medicine and cultivated for oil production (Bianco et al., 1993). It is applied topically to treat skin damage, such as contact dermatitis, atopic dermatitis, eczema including severe hand and foot eczema, psoriasis, thermal and radiation burns, other types of skin inflammation and aging (Aburjai and Natsheh, 2003). Oleuropein, the main constituent of olive leaf extract, is a complex phenol present in large quantities in olive tree leaves, inhibited platelet-activating factor activity, enhanced nitric oxide production by mouse macrophages and decreased inflammatory mediator production (Mourtzinos et al., 2007). Olive oil contains fatty acids, triglycerides, tocopherols, squalene, carotenoids, sterols, polyphenols, chlorophylls, $\beta$-sitosterol, tocopherol, volatile and flavour compounds. Olive leaves also contain flavonoids (apigenin, kaempferol, luteolin) as well as phenolic compounds (caffeic acid, tyrosol, hydroxytytrosol). Since ancient time people have been using olive oil as skin and hair conditioner in cosmetics (Alvarez and Rodriguez, 2000).

\subsection{Pelargonium graveolens L'Her.}

The technical and scientific knowledge is limited for Pelargonium graveolens (Geraniaceae), (Hsouna and Hamdi, 2013). Some scientific studies showed the presence of constituents belonging mainly to the groups of essential oils, phenolics and flavonoids (Rao et al., 2002). Geranium oil is used as cleansing for over-oily skin, for acne and for eczema. It 
is a very important component of high grade perfumes due to its strong rose-like odour (Parameswaran et al., 2000).

\subsection{Schinziophyton rautanenii Schinz}

Schinziophyton rautanenii (Euphorbiaceae), is known as mungongo in Zambia and manketti in many other African countries. It is found growing in a rough band across the subtropical latitudes of southern Africa including the Limpopo Province of South Africa. The seed oil from the species consists mainly of fatty acids including linoleic, oleic, palmitic, linolenic, and erucic acids, with lesser quantities of myristic and myristoleoic acids. In addition, it is rich in vitamin $\mathrm{E}(565 \mathrm{mg} / 100 \mathrm{~g}$ of the kernel) which provides excellent oxidative stability and a long shelf life (Juliani et al. 2007; Chivandi et al. 2008). Additionally, the presence of Vitamin E, linoleic and eleostearic acids renders the oil useful for skin protection and hydration, which may assist with reduction of inflammation and promotion of cellular repair and tissue generation (Zimba et al., 2005). Skin supplementation with anti-oxidants may play an important role in the reduction of photo damage and photo aging due to free-radical oxidative stress (Saral et al., 2002).

\subsection{Sclerocarya birrea Sond.}

Sclerocarya birrea (Anacardiaceae) is a Savannah tree commonly known as Marula, an important ethnomedicinal plant. The oil of marula contains oleic, linoleic and palmitic acid. Recent studies on the oil from Sclerocarya birrea kernels showed a high oxidative stability even during deep frying due to its fatty acid and tocopherol composition (Mariod et al., 2010). Women in the Limpopo region of South Africa use the oil to massage babies and as body lotion for face, feet and hands. Local populations in southern Africa, particularly in South Africa, have been using marula oil for several years to protect against dry and cracking skin, and as a shampoo for dry, damaged and fragile hair (Hein et al., 2009). Like many other fixed oils, marula oil is rich in monounsaturated fatty acids which make the oil very stable (Zimba et al., 2005). Marula oil has been shown to improve skin hydration and smoothness as well as to reduce skin redness (Gruenwald, 2006). Clinical tests (including skin hydration, 
'transepidermal water loss' and 'increase in skin smoothness') to determine its potential in cosmetic formulations have been completed with moderate success (Houghton, 1999).

\subsection{Sesamum indicum $\mathrm{L}$.}

Sesamum indicum (Sesame) is grown extensively in tropical and subtropical areas, is an important oilseed crop, being cultivated in the tropics and the temperate zone of the world. Defatted sesame meal is rich in protein (40-50\%), and it may be an excellent protein source. It is one of the oldest oil crops and is widely cultivated in Asia and Africa (Ali et al., 2007). The sesame seed oil is rich in oleic acid and linoleic acid (Zhang et al., 2013; Bandyopadhyay and Ghosh 2002). In the tissues beneath the skin, this oil neutralizes oxygen radicals. It penetrates into the skin quickly and enters the blood stream through the capillaries (Anilkumar et al., 2010). The oil is useful in the industrial preparation for skin conditioning agents, moisturizers and bath oils products etc. Sesame seed has higher oil content (around $50 \%$ ) than most of the known oil seeds (Warra, 2012).

\subsection{Sideroxylon inerme $\mathrm{L}$.}

Sideroxylon inerme or white milkwood is an evergreen Southern African coastal tree, is one of South Africa's 'Protected Trees'. This is the only member of the Sideroxylon genus in Southern Africa (VanWyk et al., 1997). Traditionally it is used plant for skin-lightening purposes in South African tribes by Zulus and Xhosas. The bark is used for several medicinal purposes in the form of a paste, the bark also widely used as a skin lightener, particularly in KwaZulu-Natal province of South Africa (VanWyk and Gerick, 2000). Methanol and acetone extracts from the stem bark of $S$. inerme was found to exhibited significant inhibition of monophenolase activity with $\mathrm{IC}_{50}$ values of $63 \mu \mathrm{g} / \mathrm{ml}$ and $82 \mu \mathrm{g} / \mathrm{ml}$, respectively. The methanol extract also exhibited $37 \%$ reduction of melanin content at a concentration of 6.2 $\mu \mathrm{g} / \mathrm{ml}$ in melanocytes without being significantly toxic to the cells. Two active compounds, epigallocatechin gallate and procyanidin B1 has been isolated from the stem bark of $S$. inerme, exhibited with $\mathrm{IC}_{50}$ values against monophenolase of $30 \mu \mathrm{g} / \mathrm{ml}$ and $>200 \mu \mathrm{g} / \mathrm{ml}$, respectively. The compound epigallocatechin gallate exhibited a greater anti-tyrosinase 
activity than arbutin. Both compounds also exhibited antioxidant activities with a fifty percent effective concentration ( $\mathrm{EC}_{50}$ values) of $1.33 \mu \mathrm{g} / \mathrm{ml}$ and $1.68 \mu \mathrm{g} / \mathrm{ml}$, respectively (Momtaz et al., 2008).

\subsection{Ximenia Americana L.}

Ximenia americana (Olacaceae) is a thorny bush-forming shrub or small tree of southern Africa (Maikai et al. 2010). The roots are traditionally used to treat skin problems, leprotic ulcers, mouth ulcers, haemorrhoids, abdominal pains, dysentery and venereal disease. The oil from the seed is used as an emollient, conditioner, skin softener and hair oil as well as included as an ingredient in lipsticks and lubricants (Maikai et al., 2010). Analysis of the seed oil revealed that the major components were found to be oleic, hexacos-17-enoic (ximenic), linoleic, linolenic and stearic acids together with smaller quantities of triacont-21-enoic (lumequic), octadec-11-en-9-ynoic (ximenynic), arachidonic, erucic, and nervonic acids. Fatty acids with more than 22 carbon atoms are rarely found naturally. Ximenia oil contains very long chain fatty acids with up to 40 carbon atoms. Studies on ximenynic acid $\left(\mathrm{Ximenoil}^{\circledR}\right)$ have revealed improvement in blood circulation. The greatest effect increased by $50 \%$ was seen after 60 min especially on cellulitic areas where blood perfusion is usually very low (Olabissi et al., 2011).

Table 1 depicts about 117 plant species grown in South Africa including the aforesaid ones which are applied topically or taken orally, traditionally by the South African population in several localities for inflammation, wound healing, as dressing for swollen parts, for cleaning wounds, treatment of sores, burns, eczema, boils, leprosy, as a blood cleanser, for cracked lips or skin, for fractures, for sprains and skin diseases caused by microorganisms (Dweck, 2011). A few plant species used in plant-based formulation have been scientifically proven with regard to skin care potential, but the majority of plant species used traditionally to treat various skin disorders has not been scientifically validated and therefore, need special attention for further investigations. Table 1 depicts the taxa of South Africa (few are grown or cultivated), for their medicinal and skin care usage. 
Table 1: Ethnobotanical usage of plants from South Africa for skin care

\begin{tabular}{|c|c|c|c|c|c|}
\hline Scientific name & Common name & Family & Local and ethnobotanical uses & Cosmeceutical relevance's & References \\
\hline Acacia erioloba E.Mey.* & $\begin{array}{l}\text { Camel thorn, Kameeldoring } \\
\text { (Afr.) }\end{array}$ & Fabaceae & Pods are used to treat coughs, Herpes zoster and gonorrhoea & Wood ash is used for skin infections & $\begin{array}{l}\text { Von Koenen (1996); } \\
\text { Chinsembu et al., } 2011\end{array}$ \\
\hline $\begin{array}{l}\text { Acokanthera oppositifolia (Lam.) } \\
\text { Codd }\end{array}$ & $\begin{array}{l}\text { Bushman's Poison, } \\
\text { Boesmansgif (Afr.) }\end{array}$ & Apocynaceae & $\begin{array}{l}\text { Aerial plant parts are used to treat headaches, abdominal } \\
\text { pains, convulsions, pain, snake-bite; and root decoctions are } \\
\text { used to treat tapeworm }\end{array}$ & $\begin{array}{l}\text { Leaf/root pulp is rubbed into wounds, and also } \\
\text { applied as a dressing to swollen parts }\end{array}$ & $\begin{array}{l}\text { Watt and Breyer (1962); } \\
\text { Hutchings (1996) }\end{array}$ \\
\hline Adansonia digitata $\mathrm{L}$. & $\begin{array}{l}\text { Baobab, } \\
\text { Kremetartboom (Afr.) }\end{array}$ & Malvaceae & $\begin{array}{l}\text { Whole plant is used as diaphoretic, diuretic, astringent, } \\
\text { emollient and has antiarrhythmic properties }\end{array}$ & $\begin{array}{l}\text { The entire plant part is used for inflammation and } \\
\text { aging related disorders }\end{array}$ & Caluwe et al., 2010 \\
\hline $\begin{array}{l}\text { Agapanthus campanulatus } \\
\text { Leighton* }\end{array}$ & $\begin{array}{l}\text { Bell agapanthus, } \\
\text { Bloulelie (Afr.) }\end{array}$ & Agapanthaceae & $\begin{array}{l}\text { A lotion made from crushed roots are used to bathe new- } \\
\text { born babies to make them strong }\end{array}$ & Leaves are used against blemishes & Duncan (1998) \\
\hline $\begin{array}{l}\text { Agathosma betulina } \text { (Berg.) } \\
\text { Pillans }\end{array}$ & $\begin{array}{l}\text { Boegoe, } \\
\text { Bergboegoe (Afr.) }\end{array}$ & Rutaceae & $\begin{array}{l}\text { The whole plant part is used as a diuretic, a liniment, a } \\
\text { cough remedy, to treat kidney and urinary tract infections, } \\
\text { prostatitis, rheumatism, cholera and other stomach ailments }\end{array}$ & $\begin{array}{l}\text { The plant is mixed with vinegar and is used to } \\
\text { clean wounds and in cosmetics to keep the skin } \\
\text { soft and moist in dry climates }\end{array}$ & $\begin{array}{l}\text { Van Wyk et al. (1997); Watt } \\
\text { and Breyer (1962); Simpson } \\
\text { (1998) }\end{array}$ \\
\hline $\begin{array}{l}\text { Agathosma crenulata }(\mathrm{L} .) \\
\text { Pillans* }\end{array}$ & $\begin{array}{l}\text { Oval-leaf buchu, } \\
\text { Anysboegoe (Afr.) }\end{array}$ & Rutaceae & $\begin{array}{l}\text { Leaves are used to treat stomach complaints, worms, } \\
\text { indigestion, kidney and bladder ailments }\end{array}$ & $\begin{array}{l}\text { Leaf decoctions are used for bath and for } \\
\text { cleaning wounds }\end{array}$ & $\begin{array}{l}\text { Van Rooyen and Steyn } \\
\text { (1999); Goldblatt and } \\
\text { Manning (2000) }\end{array}$ \\
\hline Aloe aculeata Pole-Evans & Red hot poker aloe & Aloaceae & Leaves are used to treat various skin ailments & Leaves are used for skin blemishes & Mapunya et al. (2012) \\
\hline Aloe arborescens Mill. & $\begin{array}{l}\text { Krantz aloe, } \\
\text { Kransaalwyn (Afr.) }\end{array}$ & Aloaceae & $\begin{array}{l}\text { Powdered leaves are used for protection against storms and } \\
\text { leaf decoctions are used for childbirth }\end{array}$ & $\begin{array}{l}\text { Leaves are used to treat burn wounds and } \\
\text { abrasions }\end{array}$ & Mapunya et al. (2012) \\
\hline Aloe ferox Mill. & $\begin{array}{l}\text { Bitter Aloe, } \\
\text { Bergaalwyn (Afr.) }\end{array}$ & Aloaceae & Sap from the leaves is used as a laxative and for arthritis & Leaf sap is used for wound healing & Mapunya et al. (2012) \\
\hline Aloe greatheadii Schonland & $\begin{array}{l}\text { Spotted aloe, } \\
\text { Transvaalaalwyn (Afr.) }\end{array}$ & Aloaceae & $\begin{array}{l}\text { The sap of the plant is used to treat arthritis, skin cancer, } \\
\text { burns, eczema, digestive problems, high blood pressure and } \\
\text { diabetes }\end{array}$ & $\begin{array}{l}\text { The bitter sap of the leaves is used to treat } \\
\text { wounds, sores and burns }\end{array}$ & $\begin{array}{l}\text { Van Wyk and Malan (1988); } \\
\text { Van Wyk and Smith (1996) }\end{array}$ \\
\hline
\end{tabular}




\begin{tabular}{|c|c|c|c|c|c|}
\hline Aloe pretoriensis Pole-Evans & Pretoria Aloe & Aloaceae & Sap is used to treat arthritis and skin irritations & The sap of the leaves is used for skin blemishes & Mapunya et al. (2012) \\
\hline Aloe sessiliflora Pole-Evans & Bottle-brush aloe & Aloaceae & $\begin{array}{l}\text { The whole plant is used to treat vomiting, bronchitis, } \\
\text { asthma, jaundice and ulcers }\end{array}$ & Leaves are used to treat skin diseases & Mapunya et al. (2012) \\
\hline Aloe vera (L.) Burm.f. & True Aloe, Barbados Aloe & Aloaceae & $\begin{array}{l}\text { The sap of the plant is used for multipurpose skin } \\
\text { treatments }\end{array}$ & $\begin{array}{l}\text { The gel from leaves is used as a remedy for } \\
\text { minor burns, scrapes and for sunburn }\end{array}$ & Mapunya et al. (2012) \\
\hline Anacardium occidentale L.* & Cashew nut & Anacardiaceae & $\begin{array}{l}\text { Fruit-bark juice is used to treat warts, cancerous ulcers, } \\
\text { dysentery, fever, leucoderma, piles and tumours }\end{array}$ & $\begin{array}{l}\text { Old leaves are applied to the skin as a poultice } \\
\text { for burns and other skin diseases }\end{array}$ & Okoye et al. (2009) \\
\hline $\begin{array}{l}\text { Antidesma venosum E. Mey. ex } \\
\text { Tul.* }\end{array}$ & $\begin{array}{l}\text { Tassle Berry, Tasselbessie } \\
\text { (Afr.) }\end{array}$ & Phyllanthaceae & $\begin{array}{l}\text { Root-bark is used for dysentery, it is chewed to treat } \\
\text { snakebite; root decoctions are used to treat abdominal pains } \\
\text { and malaria }\end{array}$ & Powdered bark is used for wound dressing & $\begin{array}{l}\text { Gerstner (1938); Palgrave } \\
\text { (2002) }\end{array}$ \\
\hline Aristea ecklonii Baker.* & $\begin{array}{l}\text { Blue stars, } \\
\text { Blousterre (Afr.) }\end{array}$ & Iridaceae & The whole plant used to treat fevers, coughs and syphilis & The whole plant is applied topically for shingles & $\begin{array}{l}\text { Hutchings et al. (1996); } \\
\text { Ngwenya et al. (2003) }\end{array}$ \\
\hline Artemisia afra Jacq. ex Willd. & $\begin{array}{l}\text { African wormwood, } \\
\text { Wilde-als (Afr.) }\end{array}$ & Asteraceae & $\begin{array}{l}\text { Roots/stems/leaves are used to treat coughs, whooping } \\
\text { cough, fever, loss of appetite, headache, diabetes and } \\
\text { intestinal worms }\end{array}$ & Roots, stems and leaves are used for body washes & $\begin{array}{l}\text { Van Wyk et al. (1997); Watt } \\
\text { and Breyer (1962) }\end{array}$ \\
\hline $\begin{array}{l}\text { Aspalathus linearis (Burm.f.) } \\
\text { R.Dahlgren }\end{array}$ & $\begin{array}{l}\text { Rooibos tea, } \\
\text { Bossietee (Afr.) }\end{array}$ & Fabaceae & $\begin{array}{l}\text { The whole plant is used for increasing appetite, for } \\
\text { improving bowel movement and for controlling mental } \\
\text { conditions }\end{array}$ & $\begin{array}{l}\text { The aerial plant part is used for anti-ageing and } \\
\text { for eczema }\end{array}$ & $\begin{array}{l}\text { Jackson (1990); Van Wyk } \\
\text { and Gericke (2000) }\end{array}$ \\
\hline Asparagus africanus Lam. & African asparagus & Asparagaceae & $\begin{array}{l}\text { The aerial plant part is used to treat headache, backache, } \\
\text { stomach pain and for child birth. The root extract is applied } \\
\text { externally for chronic gout }\end{array}$ & $\begin{array}{l}\text { The aerial plant part is used by women to } \\
\text { stimulate hair growth }\end{array}$ & Lohdip and Tyonande (2005) \\
\hline Athrixia phylicoides DC. & $\begin{array}{l}\text { Bushman's tea, Boesmanstee } \\
\text { (Afr.) }\end{array}$ & Asteraceae & $\begin{array}{l}\text { The leaf decoction is used to treat coughs, colds and as a } \\
\text { gargle for throat infections and voice loss }\end{array}$ & $\begin{array}{l}\text { Plant infusions are used as blood cleansers, and } \\
\text { to treat sores and boils }\end{array}$ & Hutchings (1996) \\
\hline Ballota africana $(\mathrm{L}$.$) Benth.*$ & $\begin{array}{l}\text { Cape horehound, } \\
\text { Kattekruie (Afr.) }\end{array}$ & Lamiaceae & $\begin{array}{l}\text { The whole plant part is used for colds, influenza, asthma, } \\
\text { bronchitis, hoarseness, heart trouble, hysteria, insomnia, }\end{array}$ & $\begin{array}{l}\text { The leaf decoction is applied externally to treat } \\
\text { sores }\end{array}$ & $\begin{array}{l}\text { Codd (1985); Van Wyk et al. } \\
\text { (1997) }\end{array}$ \\
\hline
\end{tabular}




\begin{tabular}{|c|c|c|c|c|c|}
\hline & & & typhoid fever, headaches and liver problems & & \\
\hline Bauhinia bowkeri Harv. & $\begin{array}{l}\text { Kei White Bauhinia, } \\
\text { Keibeesklou (Afr.) }\end{array}$ & Fabaceae & Leaves and bark are used to induce vomiting & $\begin{array}{l}\text { Leaves and bark are used for steaming and } \\
\text { bathing }\end{array}$ & Ndawonde et al. (2007) \\
\hline Bauhinia petersiana Bolle & Kalahari White Bauhinia & Fabaceae & $\begin{array}{l}\text { Roots are used for treating infertility in females, } \\
\text { dysmenorrhea and diarrhoea }\end{array}$ & Leaves mixed with salt are used to heal wounds. & Ahmed et al. (2012) \\
\hline Bauhinia variegata $\mathrm{L}$. & $\begin{array}{l}\text { Orchid tree, Camel's Foot } \\
\text { Tree and Mountain-ebony }\end{array}$ & Fabaceae & $\begin{array}{l}\text { The leaves are frequently used for coughs, asthma, } \\
\text { abdominal distension, diarrhoea and as a gargle for sore } \\
\text { throats }\end{array}$ & $\begin{array}{l}\text { Bark decoction is used for skin diseases and is } \\
\text { helpful in managing skin discoloration }\end{array}$ & $\begin{array}{l}\text { Kirtikar and Basu (1975); } \\
\text { Ahmed et al. (2012) }\end{array}$ \\
\hline $\begin{array}{l}\text { Becium obovatum E. Mey. ex } \\
\text { Benth.* }\end{array}$ & $\begin{array}{l}\text { Cat's whiskers, } \\
\text { Katsnor (Afr.) }\end{array}$ & Lamiaceae & $\begin{array}{l}\text { Roots and leaves are administered as enemas to treat } \\
\text { stomach ailments as well as for abdominal pains }\end{array}$ & $\begin{array}{l}\text { Pounded roots and leaf infusions in warm water } \\
\text { are applied for inflammations }\end{array}$ & $\begin{array}{l}\text { Pooley (1998); Fawole et al. } \\
\text { (2009) }\end{array}$ \\
\hline Boophane disticha (L.f.) Herb.* & $\begin{array}{l}\text { Century plant, } \\
\text { Seerooglelie (Afr.) }\end{array}$ & Amaryllidaceae & $\begin{array}{l}\text { Bulbs are used to treat hysteria in young women; and fresh } \\
\text { leaves are used to treat wound }\end{array}$ & $\begin{array}{l}\text { Bulbs are used to treat wounds and are applied to } \\
\text { boils and abscesses }\end{array}$ & $\begin{array}{l}\text { Van Wyk et al., (1997); } \\
\text { Van Wyk and Malan (1988) }\end{array}$ \\
\hline Bulbine frutescens (L.) Willd. & $\begin{array}{l}\text { Snake flower, Geelkatstert } \\
\text { (Afr.) }\end{array}$ & Asphodelaceae & $\begin{array}{l}\text { Fresh leaf decoctions are taken for coughs, colds, arthritis, } \\
\text { insect bites and for improving wound healing }\end{array}$ & $\begin{array}{l}\text { Fresh leaf juice is used for burns, cracked lips } \\
\text { and acne }\end{array}$ & Dyson (1998); Joffe (1993) \\
\hline Calendula officinalis $\mathrm{L}$. & Pot marigold & Asteraceae & $\begin{array}{l}\text { Leaf decoctions are used to treat fevers, cancer and for } \\
\text { menstruation problem }\end{array}$ & $\begin{array}{l}\text { Tinctures and balms made from the flowers are } \\
\text { applied to the skin to heal wounds and damaged } \\
\text { skin }\end{array}$ & $\begin{array}{l}\text { Mozherenkov and Shubina } \\
\text { (1976); Muley et al. (2009) }\end{array}$ \\
\hline $\begin{array}{l}\text { Calodendrum capense (L.f.) } \\
\text { Thunb. }\end{array}$ & $\begin{array}{l}\text { Cape Chestnut, } \\
\text { Wildekastaiing (Afr.) }\end{array}$ & Rutaceae & $\begin{array}{l}\text { Leaves are used to kill insects. Seed oil is used for making } \\
\text { soap }\end{array}$ & $\begin{array}{l}\text { The bark is used as an ingredient for skin } \\
\text { ointments }\end{array}$ & $\begin{array}{l}\text { Leistner (2000); Palmer and } \\
\text { Pitman (1972) }\end{array}$ \\
\hline $\begin{array}{l}\text { Carpobrotus dimidiatus (Haw.) } \\
\text { L. Bolus* }\end{array}$ & $\begin{array}{l}\text { Natal sour fig, } \\
\text { Natalse strandvy (Afr.) }\end{array}$ & $\begin{array}{l}\text { Mesembryanthe- } \\
\text { maceae }\end{array}$ & $\begin{array}{l}\text { The leaf juice is used as a gargle for sore throats, digestive } \\
\text { troubles, diarrhoea and dysentery }\end{array}$ & $\begin{array}{l}\text { Leaf juice is used for dressing burns and as an } \\
\text { ointment }\end{array}$ & $\begin{array}{l}\text { Fox and Norwood (1982); } \\
\text { Joffe (2003) }\end{array}$ \\
\hline Carpobrotus edulis (L.) L.Bolus & $\begin{array}{l}\text { Sour fig, Cape fig, } \\
\text { Hottentotsvy (Afr.) }\end{array}$ & $\begin{array}{l}\text { Mesembryanthe- } \\
\text { maceae }\end{array}$ & $\begin{array}{l}\text { The leaf is used to treat diarrhoea, dysentery, stomach } \\
\text { cramps, diphtheria, mouth infections, ulcers, toothache and } \\
\text { is also used as an astringent }\end{array}$ & $\begin{array}{l}\text { The leaf juice is used as a lotion for burns, } \\
\text { bruises, scrape, cuts, sunburn, eczema, dermatitis } \\
\text { and other skin conditions }\end{array}$ & $\begin{array}{l}\text { Germishuizen and Meyer } \\
\text { (2003); Roberts (1990) }\end{array}$ \\
\hline Centella asiatica (L.) Urban & Udingu (Afr.) & Apiaceae & The leaves are used to treat anaemia, dermatitis, bronchitis, & Plant extract is applied for wound healing, & Zainol et al. (2003); Cheng \\
\hline
\end{tabular}




\begin{tabular}{|c|c|c|c|c|c|}
\hline & & & $\begin{array}{l}\text { asthma, cholera, constipation, diarrhoea, dysentery, } \\
\text { epilepsy, hypertension, jaundice, leucorrhoea, nervous } \\
\text { disorders and smallpox }\end{array}$ & $\begin{array}{l}\text { related skin infections and poultices are used to } \\
\text { treat closed fractures and sprains }\end{array}$ & and Koo (2000) \\
\hline $\begin{array}{l}\text { Cheilanthes viridis (Forssk.) } \\
\text { Sw.* }\end{array}$ & Green cliffbrake & Pteridaceae & The whole plant part is used for wound & The whole plant part is used to treat sores & Kelmanson et al. (2000) \\
\hline Chenopodium ambrosioides $\mathrm{L}$. & Sweet pigweed & Chenopodiaceae & $\begin{array}{l}\text { The entire plant is used for flatulence, influenza, typhoid } \\
\text { fever and pneumonia }\end{array}$ & $\begin{array}{l}\text { Plant decoctions are used to treat eczema and } \\
\text { wounds }\end{array}$ & $\begin{array}{l}\text { Pesewu et al. (2008); } \\
\text { Hutchings (1996) }\end{array}$ \\
\hline Cissampelos capensis $\mathrm{L} . *$ & Dawidjieswortel (Afr.) & Menispermaceae & $\begin{array}{l}\text { Roots are used for snakebite, diabetes, syphilis, } \\
\text { tuberculosis, stomach and skin cancers }\end{array}$ & $\begin{array}{l}\text { Rhizomes/roots/leaf paste are used for boils, } \\
\text { wounds, ulcers and sores }\end{array}$ & $\begin{array}{l}\text { Van Wyk et al. (2000); } \\
\text { Babajide et al. (2010); Wet et } \\
\text { al. (2011) }\end{array}$ \\
\hline $\begin{array}{l}\text { Citrullus lanatus (Thunb.) } \\
\text { Matsum. \& Nakai }\end{array}$ & $\begin{array}{l}\text { Wild watermelon, } \\
\text { Bitterboela (Afr.) }\end{array}$ & Cucurbitaceae & $\begin{array}{l}\text { The fruit is used to treat enlarged livers, jaundice, for } \\
\text { kidneys and bladder infection and for high blood pressure }\end{array}$ & $\begin{array}{l}\text { The flesh of fruits is used as an ingredient of sun } \\
\text { lotions and other cosmetics }\end{array}$ & $\begin{array}{l}\text { Laghetti and Hammer } \\
\text { (2007); Raimondo et al. } \\
\text { (2009) }\end{array}$ \\
\hline $\begin{array}{l}\text { Clausena anisata (Willd) Hook.f. } \\
\text { ex Benth. }\end{array}$ & $\begin{array}{l}\text { Mkomavikali Nukamdida } \\
\text { (Afr.) }\end{array}$ & Rutaceae & $\begin{array}{l}\text { A decoction of leaves/roots is used to treat gastro-intestinal } \\
\text { disorders and sore throats }\end{array}$ & $\begin{array}{l}\text { Crushed leaves are applied externally as an } \\
\text { antiseptic for wounds, sores and burns }\end{array}$ & $\begin{array}{l}\text { Clarkson et al. (2004); } \\
\text { Hutchings et al. (1996) }\end{array}$ \\
\hline $\begin{array}{l}\text { Clerodendrum glabrum E.Mey. } \\
\text { var. glabrum* }\end{array}$ & $\begin{array}{l}\text { Tinderwood, } \\
\text { Tontelhout (Afr.) }\end{array}$ & Verbenaceae & $\begin{array}{l}\text { The roots are used to treat the snakebites and leaves } \\
\text { decoctions are used to treat diarrhoea }\end{array}$ & $\begin{array}{l}\text { Decoctions of leaves are used for treating } \\
\text { wounds }\end{array}$ & Van Wyk et al., (2007) \\
\hline Crinum moorei Hook. f. & Natal lily, Boslelie (Afr.) & Amaryllidaceae & $\begin{array}{l}\text { The bulbs are used for urinary tract infections and to treat } \\
\text { body swelling }\end{array}$ & $\begin{array}{l}\text { Bulbs are used as blood cleansers and to treat } \\
\text { infected sores and acne }\end{array}$ & $\begin{array}{l}\text { Fawole et al. (2010); } \\
\text { Hutchings et al. (1996) }\end{array}$ \\
\hline Crocus sativus L. & Saffron & Iridaceae & $\begin{array}{l}\text { Used to treat dysentery, enlargement of the liver, urological } \\
\text { infections, coughs, stomach disorders and asthma }\end{array}$ & The whole plant is used for skin blemishes & $\begin{array}{l}\text { Assimopoulou et al. (2005); } \\
\text { Sariri et al. (2011) }\end{array}$ \\
\hline Croton sylvaticus Hochst.* & $\begin{array}{l}\text { woodland croton, } \\
\text { Boskoorsbessie (Afr.) }\end{array}$ & Euphorbiaceae & Bark is used to treat rheumatism and intestinal disorders & Leaves are made into a poultice to treat pleurisy & $\begin{array}{l}\text { Lans (2007); Schmidt et al. } \\
\text { (2002) }\end{array}$ \\
\hline Cucumis hirsutus Sond. & Volunteer cucumber & Cucurbitaceae & Leaf and root decoctions are used for diarrhoea & Leaves and roots are used for inflammation & $\begin{array}{l}\text { Hutchings et al. (1996); } \\
\text { Fawole et al. (2009) }\end{array}$ \\
\hline
\end{tabular}




\begin{tabular}{|c|c|c|c|c|c|}
\hline Cyclopia intermedia E. Mey. & Honeybush tea & Fabaceae & $\begin{array}{l}\text { Leaf decoctions are used as a diuretic, to treat diarrhoea, } \\
\text { menstruation cycles, uterus and prostate cancer }\end{array}$ & $\begin{array}{l}\text { Leaf decoctions are used to wash wounds and } \\
\text { burns }\end{array}$ & $\begin{array}{l}\text { McKay and Blumberg } \\
\text { (2007); Marnewick et al. } \\
\text { (2005) }\end{array}$ \\
\hline Cyperus textilis Thunb.* & $\begin{array}{l}\text { Basket grass, Kooigoed } \\
\text { (Afr.) }\end{array}$ & Cyperaceae & The plant is used for making baskets and mats & Rhizomes are used for skin ailments & $\begin{array}{l}\text { Nadkarni (1976); Smith } \\
\text { (1966) }\end{array}$ \\
\hline Datura stramonium $\mathrm{L}$. & Thorn apple & Solanaceae & $\begin{array}{l}\text { The leaves are used to treat gastrointestinal problems, } \\
\text { asthma, arthritis, headaches, sprains, haemorrhoids and } \\
\text { tumours }\end{array}$ & $\begin{array}{l}\text { The leaves are used to treat wounds, sores, } \\
\text { swellings, boils, abscesses, bruises and } \\
\text { inflammation }\end{array}$ & van Wyk et al., 2000 \\
\hline Dicoma anomala Sond. & $\begin{array}{l}\text { Fever bush, Koorsbossie } \\
\text { (Afr.) }\end{array}$ & Asteraceae & $\begin{array}{l}\text { Root decoctions are used to treat diarrhoea, dysentery and } \\
\text { intestinal worms }\end{array}$ & Root decoctions are used for sores and wounds & $\begin{array}{l}\text { Retief and Herman (1997); } \\
\text { Pooley (1998) }\end{array}$ \\
\hline Diospyros lycioides Desf. & $\begin{array}{l}\text { Monkey plum, Bloubos } \\
\text { (Afr.) }\end{array}$ & Ebenaceae & Bark/root decoctions are used for dysentery & $\begin{array}{l}\text { Bark and root decoctions are used for } \\
\text { inflammation }\end{array}$ & $\begin{array}{l}\text { Van Wyk and Van Wyk } \\
\text { (1997) }\end{array}$ \\
\hline $\begin{array}{l}\text { Detarium microcarpum Guill. \& } \\
\text { Perr.* }\end{array}$ & $\begin{array}{l}\text { Sweet detar, } \\
\text { Sweet dattock (Afr.) }\end{array}$ & Fabaceae & $\begin{array}{l}\text { The bark/leaves/root decoctions are used to treat } \\
\text { rheumatism, venereal diseases, urogenital infections, } \\
\text { diarrhoea, dysentery, intestinal worms, malaria and for } \\
\text { painful menstruation }\end{array}$ & $\begin{array}{l}\text { Fresh bark or leaves are applied to wounds to } \\
\text { prevent and to cure infections }\end{array}$ & $\begin{array}{l}\text { Abreu et al. (1998); Pooley } \\
\text { (1998) }\end{array}$ \\
\hline $\begin{array}{l}\text { Diospyros mespiliformis Hochst. } \\
\text { ex A.DC. }\end{array}$ & $\begin{array}{l}\text { African ebony, Jakkalsbessie } \\
\text { (Afr.) }\end{array}$ & Ebenaceae & $\begin{array}{l}\text { Leaf decoctions are used for whooping cough, fever, } \\
\text { malaria, leprosy and dermatomycoses }\end{array}$ & Leaves are used for skin infections and wounds & Mohamed et al. (2009) \\
\hline Ekebergia capensis Sparrm.* & Cape ash, Essenhout (Afr.) & Meliaceae & $\begin{array}{l}\text { Root decoctions are used for headaches and chronic coughs; } \\
\text { bark is used to cure dysentery and the leaves are used for } \\
\text { intestinal worms }\end{array}$ & $\begin{array}{l}\text { Bark infusion is used for boils, acne and } \\
\text { abscesses }\end{array}$ & $\begin{array}{l}\text { Pujol (1990); Van Wyk et al. } \\
\text { (2011); Ndukui et al. (2012) }\end{array}$ \\
\hline Elaeis guineensis Jacq & African oil palm & Arecaceae & $\begin{array}{l}\text { Leaves are used for headaches, gonorrhoea, menorrhagia } \\
\text { and bronchitis }\end{array}$ & $\begin{array}{l}\text { The leaf extract is applied on fresh wounds and } \\
\text { fruit mesocarp oil is used externally as a lotion to } \\
\text { treat skin disease }\end{array}$ & Sasidharan et al. (2010) \\
\hline Elephantorrhiza elephantina & Elephant's root, Leerbossie & Fabaceae & Roots are used for dysentery, diarrhoea, intestinal disorders, & Underground parts are used to treat sunburn and & Van Wyk et al., 1997 \\
\hline
\end{tabular}




\begin{tabular}{|c|c|c|c|c|c|}
\hline (Burch.) Skeels & (Afr.) & & haemorrhoids and for syphilis & root infusion is used to treat acne & \\
\hline $\begin{array}{l}\text { Embelia ruminate (E.Mey. ex } \\
\text { A.Dc.) Mez* }\end{array}$ & False black pepper & Myrsinaceae & Leaves are used as an anti-anthelmintic & $\begin{array}{l}\text { Leaf paste is used to treat open wounds and for } \\
\text { leprosy related infections }\end{array}$ & Kumaraswamy et al. (2007) \\
\hline Eriocephalus africanus $\mathrm{L}$. & $\begin{array}{l}\text { Wild Rosemary, } \\
\text { Wilderoosmaryn (Afr.) }\end{array}$ & Asteraceae & $\begin{array}{l}\text { Leaf decoctions are used for dropsy, coughs, delayed } \\
\text { menstruation, swelling and for gynaecological problems }\end{array}$ & $\begin{array}{l}\text { The yellow oil is used for skin care and is an } \\
\text { important constituent of cosmetics products }\end{array}$ & $\begin{array}{l}\text { Gericke et al. (1997); Dyson } \\
\text { (1998) }\end{array}$ \\
\hline Eriocephalus punctulatus $\mathrm{L}$. & $\begin{array}{l}\text { Wild rosemary, Kapokbos } \\
\text { (Afr.) }\end{array}$ & Asteraceae & $\begin{array}{l}\text { Leaves are used for the urinary infections and for stomach } \\
\text { diseases }\end{array}$ & $\begin{array}{l}\text { Oil has anti-allergic and anti-septic properties } \\
\text { and is used in aromatherapy }\end{array}$ & Sandasi et al. (2011) \\
\hline Erythrina lysistemon Hutch. & $\begin{array}{l}\text { Common coral tree, Gewone } \\
\text { (Afr.) }\end{array}$ & Fabaceae & $\begin{array}{l}\text { The aerial plant part is used for arthritis and to relieve } \\
\text { earache, root decoctions are used for sprains }\end{array}$ & $\begin{array}{l}\text { Bark is applied as a poultice to treat sores, } \\
\text { wounds and abscesses }\end{array}$ & Pillay et al. (2001) \\
\hline Eucalyptus camaldulensis Dehnh. & $\begin{array}{l}\text { Rostrata gum, Rooibloekom } \\
\text { (Afr.) }\end{array}$ & Myrtaceae & $\begin{array}{l}\text { The aerial plant part is used for colds and influenza, the oil } \\
\text { is used as an antiseptic }\end{array}$ & Bark infusion is used to treat pimples & $\begin{array}{l}\text { Mabona et al. (2013); } \\
\text { Hutchings (1996) }\end{array}$ \\
\hline Ficus natalensis Hochst.* & Natal Fig & Moraceae & $\begin{array}{l}\text { Leaf decoctions are used to treat various stomach disorders. } \\
\text { Bark is used during pregnancy to ensure easy childbirth. } \\
\text { Roots are administrated for blood purification }\end{array}$ & $\begin{array}{l}\text { Leaves are used as poultices for wounds and } \\
\text { boils }\end{array}$ & $\begin{array}{l}\text { Gerstner (1941); Pujol } \\
\text { (1990); Corrigan et al. (2011) }\end{array}$ \\
\hline Foeniculum vulgare Mill. & $\begin{array}{l}\text { Wild Fennel, } \\
\text { Bobbejaanvinkel (Afr.) }\end{array}$ & Umbelliferae & $\begin{array}{l}\text { The whole plant part is used for arthritis, fever, gastric- } \\
\text { intestinal complaints, diarrhoea and as a milk stimulant in } \\
\text { pregnant women }\end{array}$ & $\begin{array}{l}\text { Seed and root decoctions are used as a blood } \\
\text { cleanser }\end{array}$ & $\begin{array}{l}\text { Watt and Breyer (1962); Van } \\
\text { Wyk et al. (1997) }\end{array}$ \\
\hline Galenia africana L.* & $\begin{array}{l}\text { Yellow Bush, } \\
\text { Brakkraalbossie (Afr.) }\end{array}$ & Aizoaceae & $\begin{array}{l}\text { The whole plant part is used to treat venereal sores, asthma, } \\
\text { coughs, wounds, eye infections and skin diseases }\end{array}$ & $\begin{array}{l}\text { A lotion made from the plant decoction are used } \\
\text { for inflammation and for skin diseases }\end{array}$ & Van der Lugt et al. (1992) \\
\hline Grewia occidentalis L.* & $\begin{array}{l}\text { Cross-berry, Kruisbessie } \\
\text { (Afr.) }\end{array}$ & Malvaceae & $\begin{array}{l}\text { Bark is used to facilitate child delivery and for bladder } \\
\text { ailments }\end{array}$ & $\begin{array}{l}\text { Small twigs and leaf infusion are used for } \\
\text { wounds }\end{array}$ & $\begin{array}{l}\text { Grierson and Afolayan } \\
\text { (1999) }\end{array}$ \\
\hline Greyia flanaganii Bolus & $\begin{array}{l}\text { Kei bottlebrush, Kei } \\
\text { baakhout (Afr.) }\end{array}$ & Greyiaceae & An infusion of the powdered bark is used to treat diarrhoea & No traditional usage for skin recorded & Mapunya et al. (2011) \\
\hline
\end{tabular}




\begin{tabular}{|c|c|c|c|c|c|}
\hline Gunnera perpensa $\mathrm{L}$. & $\begin{array}{l}\text { River pumpkin, Wilde } \\
\text { ramenas (Afr.) }\end{array}$ & Gunneraceae & $\begin{array}{l}\text { A aqueous decoction of the entire plant is used for } \\
\text { rheumatic fever, infertility in women and to ease childbirth }\end{array}$ & $\begin{array}{l}\text { Root, rhizome, leaf decoctions are used for } \\
\text { dressing wounds and to treat psoriasis }\end{array}$ & $\begin{array}{l}\text { Van Wyk et al. (2009); } \\
\text { Mabona et al. (2013) }\end{array}$ \\
\hline Halleria lucida $\mathrm{L}$. & Tree Fuchsia, Notsung (Afr.) & Scrophulariaceae & The whole plant part is used for to relieve earache & $\begin{array}{l}\text { The whole plant part is used topically for various } \\
\text { skin diseases }\end{array}$ & $\begin{array}{l}\text { Pooley (1993); Hutchings } \\
\text { (1996) }\end{array}$ \\
\hline $\begin{array}{l}\text { Harpagophytum procumbens } \\
\text { (Burch.) DC. ex Meisn. }\end{array}$ & $\begin{array}{l}\text { Devil's claw, Duivelsklou } \\
\text { (Afr.) }\end{array}$ & Pedaliaceae & $\begin{array}{l}\text { The whole plant part is used as an anti-rheumatic, laxative, } \\
\text { sedative, to treat coughs, diarrhoea, diabetes, bleeding } \\
\text { gums, gonorrhoea }\end{array}$ & $\begin{array}{l}\text { Plant infusions help to heal ulcers, boils, skin } \\
\text { lesions and wounds, also used for blood } \\
\text { purification }\end{array}$ & $\begin{array}{l}\text { Neuwinger (2000); Powell } \\
\text { (2001) }\end{array}$ \\
\hline $\begin{array}{l}\text { Harpephyllum caffrum Bernh. ex } \\
\text { Krauss }\end{array}$ & $\begin{array}{l}\text { Wild plum, Wildepruim } \\
\text { (Afr.) }\end{array}$ & Anacardiaceae & Powdered burnt bark is used to treat sprains & $\begin{array}{l}\text { Bark is applied externally to treat acne and } \\
\text { eczema. Bark is applied in the form of facial } \\
\text { saunas and skin washes }\end{array}$ & $\begin{array}{l}\text { Pujol (1990); Van Wyk et al. } \\
\text { (2011); Van Wyk et al. } \\
\text { (2000) }\end{array}$ \\
\hline Helichrysum odoratissimum L.* & Imphepho, Kooigoed (Afr.) & Asteraceae & $\begin{array}{l}\text { Leaves and stems are widely used for insomnia, coughs and } \\
\text { colds }\end{array}$ & Leaf decoctions are used for pimples & Hutchings (1996) \\
\hline $\begin{array}{l}\text { Hyaenanche globosa (Gaertn.) } \\
\text { Lamb. \& Vahl }\end{array}$ & $\begin{array}{l}\text { Hyaena-poison, Gifboom } \\
\text { (Afr.) }\end{array}$ & Euphorbiaceae & $\begin{array}{l}\text { Fruits and seeds are used to poison carcasses with the } \\
\text { purpose of destroying hyenas }\end{array}$ & -- & $\begin{array}{l}\text { Momtaz et al. (2010) } \\
\text { Momtaz et al. (2008) }\end{array}$ \\
\hline Hypericum perforatum $\mathrm{L}$. & $\begin{array}{l}\text { Goatweed, Johanneskruid } \\
\text { (Afr.) }\end{array}$ & Hypericaceae & $\begin{array}{l}\text { The aerial plant part is used as a popular remedy for } \\
\text { depression, anxiety and inflammation }\end{array}$ & $\begin{array}{l}\text { Aerial parts are applied externally to treat } \\
\text { wounds }\end{array}$ & $\begin{array}{l}\text { Savikin et al. (2007); Van } \\
\text { Wyk et al. (2000) }\end{array}$ \\
\hline Ilex mitis (L.) Radlk.* & $\begin{array}{l}\text { Cape holly, Waterboom } \\
\text { (Afr.) }\end{array}$ & Aquifoliaceae & $\begin{array}{l}\text { Stem bark is used to treat fever and } \\
\text { rheumatism }\end{array}$ & $\begin{array}{l}\text { Ground bark decoction is used for skin rashes } \\
\text { and sores on the face }\end{array}$ & Mabona et al. (2013) \\
\hline Kigelia africana (Lam.) Benth. & $\begin{array}{l}\text { Sausage tree, Worsboom } \\
\text { (Afr.) }\end{array}$ & Bignoniaceae & $\begin{array}{l}\text { Bark is administrated for dysentery, rheumatism, diarrhoea } \\
\text { and for the treatment of impotence, syphilis, toothache and } \\
\text { rheumatism }\end{array}$ & $\begin{array}{l}\text { Bark decoctions are externally applied to treat } \\
\text { sores and acne }\end{array}$ & $\begin{array}{l}\text { Mabona et al. (2013); Iwu } \\
\text { (1986); Gabriel and } \\
\text { Olubunmi (2009) }\end{array}$ \\
\hline Leonotis leonurus (L.) R.Br. & $\begin{array}{l}\text { Wild dagga, Duiwelstabak } \\
\text { (Afr.) }\end{array}$ & Lamiaceae & $\begin{array}{l}\text { The whole plant part is used for fever, arthritis, swollen } \\
\text { glands, mouth ulcers }\end{array}$ & $\begin{array}{l}\text { The whole plant part is used to treat boils, } \\
\text { eczema, skin ailments and for itching }\end{array}$ & Frum (2006) \\
\hline Leucosidea sericea Eckl. \& Zeyh. & Oldwood, Ouhout (Afr.) & Rosaceae & $\begin{array}{l}\text { The paste made from the crushed leaves used to treat } \\
\text { ophthalmia }\end{array}$ & -- & Van Wyk et al. (1997) \\
\hline
\end{tabular}




\begin{tabular}{|c|c|c|c|c|c|}
\hline Lippia javanica (Burm.f.) Spreng & $\begin{array}{l}\text { Lemon Bush, Lemoenbossie } \\
\text { (Afr.) }\end{array}$ & Verbenaceae & $\begin{array}{l}\text { Plant infusion is used to treat coughs, colds, bronchial } \\
\text { problems, malaria, influenza and measles }\end{array}$ & $\begin{array}{l}\text { Plant infusion is applied to treat various skin } \\
\text { disorders such as heat rash and scabies }\end{array}$ & $\begin{array}{l}\text { Van Wyk et al. (1997); Van } \\
\text { Wyket al. (2000); Pooley } \\
\text { (1998) }\end{array}$ \\
\hline Malva parviflora $\mathrm{L}$. & $\begin{array}{l}\text { Cheeseweed, Kasieblaar } \\
\text { (Afr.) }\end{array}$ & Malvaceae & $\begin{array}{l}\text { Leaves are used to treat stomach pains, decoctions of roots } \\
\text { or leaves are used as a hair rinse to remove dandruff and to } \\
\text { soften hair }\end{array}$ & $\begin{array}{l}\text { Leaf paste combined with other plant species are } \\
\text { used to treat wounds and abscesses }\end{array}$ & $\begin{array}{l}\text { Smith (1895); Watt and } \\
\text { Breyer (1962) }\end{array}$ \\
\hline Melianthus comosus $\mathrm{L}$. & Honey Flower & Melianthaceae & $\begin{array}{l}\text { Leaf decoctions are used to treat bruises, backache, } \\
\text { rheumatic joints and snakebite }\end{array}$ & $\begin{array}{l}\text { Leaf poultices and decoctions are widely used to } \\
\text { treat septic wounds and sores }\end{array}$ & Van Wyk et al. (1997) \\
\hline Melianthus major $\mathrm{L}$. & Giant honey flower & Melianthaceae & Leaves are used to treat cancer, rheumatism and ringworm & $\begin{array}{l}\text { Leaf infusion are applied to septic wounds, } \\
\text { pimples, sores and bruises }\end{array}$ & $\begin{array}{l}\text { Philander (2011); Van Wyk } \\
\text { et al. (2009) }\end{array}$ \\
\hline Mentha longifolia (L.) Huds. & Wild mint, Balderjan (Afr.) & Lamiaceae & $\begin{array}{l}\text { Leaves are used as a general health tonic, for respiratory } \\
\text { problems and urinary tract infections }\end{array}$ & Leaves are applied topically to treat wounds & Philander (2011) \\
\hline $\begin{array}{l}\text { Olea europaea L. subsp. africana } \\
\text { (Mill.) P.S.Green }\end{array}$ & Wild olive, Olienhout (Afr.) & Oleaceae & $\begin{array}{l}\text { Bark is used to treat strokes, heart disease, palpitations and } \\
\text { to lower blood pressure }\end{array}$ & $\begin{array}{l}\text { Leaves and bark are used for eye infections and } \\
\text { for skin disorders }\end{array}$ & Philander (2011) \\
\hline Oncosiphon suffruticosum $\mathrm{L} . *$ & $\begin{array}{l}\text { Stinkkruid, Wurmkruid } \\
\text { (Afr.) }\end{array}$ & Asteraceae & $\begin{array}{l}\text { An infusion of the aerial part of plant is taken orally to treat } \\
\text { stomach pains, colds, influenza, intestinal worms, typhoid } \\
\text { fever and rheumatic fever }\end{array}$ & $\begin{array}{l}\text { A poultice of the leaves is applied for } \\
\text { inflammation and scorpion stings }\end{array}$ & $\begin{array}{l}\text { Van Wyk (2008); Van Wyk } \\
\text { et al. (2009) }\end{array}$ \\
\hline $\begin{array}{l}\text { Osmitopsis asteriscoides (P.J. } \\
\text { Bergius) Less.* }\end{array}$ & $\begin{array}{l}\text { Mountain daisy, Belsbossie } \\
\text { (Afr.) }\end{array}$ & Asteraceae & $\begin{array}{l}\text { Leaves are used for fever, colds, dyspepsia, pain, paralysis } \\
\text { and to reduce swelling }\end{array}$ & $\begin{array}{l}\text { The dried plant is used externally for } \\
\text { inflammation, cuts and swelling }\end{array}$ & Van Wyk et al. (1997) \\
\hline $\begin{array}{l}\text { Pelargonium cucullatum }(\mathrm{L}) \\
\text { L'Her. }\end{array}$ & Wilde malva & Geraniaceae & $\begin{array}{l}\text { The entire plant part used to treat diarrhoea and for the } \\
\text { relief of earache }\end{array}$ & $\begin{array}{l}\text { The entire plant part is used as an antiseptic } \\
\text { dressing for open sores or wounds }\end{array}$ & Van der Walt (1977) \\
\hline Pelargonium graveolens L'Her. & Rose-scented pelargonium & Geraniaceae & $\begin{array}{l}\text { The entire plant part used as a diuretic, for depression and } \\
\text { respiratory disorders }\end{array}$ & $\begin{array}{l}\text { The entire plant part is used to treat acne and } \\
\text { dermatitis }\end{array}$ & $\begin{array}{l}\text { Van der Walt and Vorster } \\
\text { (1988) }\end{array}$ \\
\hline Pelargonium luridum Andr. & Umsongelo (Afr.) & Geraniaceae & A root infusion is used to treat backache, abdominal pains & The leaf decoctions is used to treat skin sores & Van Wyk et al. (1997); Watt \\
\hline
\end{tabular}




\begin{tabular}{|c|c|c|c|c|c|}
\hline & & & in infants, to reduce fever, diarrhoea and dysentery & & and Breyer (1962) \\
\hline Pelargonium sidoides $\mathrm{DC}$. & Kalwerbossie (Afr.) & Geraniaceae & $\begin{array}{l}\text { The plant is used to treat coughs, sore throats, respiratory } \\
\text { ailments, diarrhoea and gonorrhoea }\end{array}$ & $\begin{array}{l}\text { The entire plant part is used for various skin } \\
\text { disorders }\end{array}$ & Watt and Breyer (1962) \\
\hline $\begin{array}{l}\text { Pentanisia prunelloides (Klotzsch } \\
\text { ex Eckl. \& Zeyh.) Walp. }\end{array}$ & $\begin{array}{l}\text { Wild verbena, } \\
\text { Sooibrandbossie (Afr.) }\end{array}$ & Rubiaceae & $\begin{array}{l}\text { Root decoctions are taken orally for vomiting, rheumatism, } \\
\text { heartburn, tuberculosis, fever, toothache and snakebite }\end{array}$ & $\begin{array}{l}\text { Root decoctions are applied externally for burns } \\
\text { and for swellings }\end{array}$ & $\begin{array}{l}\text { Pooley (1998); van Wyk et } \\
\text { al. (2000); van Wyk et al. } \\
\text { (1997) }\end{array}$ \\
\hline Polystichum pungens Roth* & Shield ferns & Dryopteridaceae & $\begin{array}{l}\text { A decoction obtained from the rhizomes is used to treat } \\
\text { intestinal worms and is also used for respiratory problems, } \\
\text { as a general anthelmintic }\end{array}$ & $\begin{array}{l}\text { Powdered dried fronds are sprinkled on wounds. } \\
\text { The fresh fronds are applied as a poultice }\end{array}$ & Jacobsen (1983) \\
\hline Protea repens $\mathrm{L}$. & $\begin{array}{l}\text { Common sugarbush, } \\
\text { Suikerbos (Afr.) }\end{array}$ & Proteaceae & Syrup made from the nectar is used to treat diabetes & Leaves are used for inflammation & Watt and Breyer (1962) \\
\hline Protea simplex E. Phillips & $\begin{array}{l}\text { Common sugarbush, } \\
\text { Suikerbos (Afr.) }\end{array}$ & Proteaceae & $\begin{array}{l}\text { Root and bark infusions are used for dysentery, diarrhoea } \\
\text { and stomach pains }\end{array}$ & The entire plant part are used for inflammation & Hutchings et al. (1996) \\
\hline Rauvolfia caffra Sond. & $\begin{array}{l}\text { Quinine tree, Kinaboom } \\
\text { (Afr.) }\end{array}$ & Apocynaceae & $\begin{array}{l}\text { The bark and latex is used to treat coughs, diarrhoea and } \\
\text { other stomach ailments }\end{array}$ & $\begin{array}{l}\text { Bark infusion are used for wounds and skin } \\
\text { rashes }\end{array}$ & $\begin{array}{l}\text { Gerstner (1938); Hutchings } \\
\text { (1996) }\end{array}$ \\
\hline Rothmannia capensis Thunb.* & $\begin{array}{l}\text { Wild gardenia, } \\
\text { Wildekatjiepiering (Afr.) }\end{array}$ & Rubiaceae & $\begin{array}{l}\text { Powdered roots are used for treating leprosy and } \\
\text { rheumatism. Sap from the fruit is applied topically for burns } \\
\text { and wounds }\end{array}$ & $\begin{array}{l}\text { Warm fruit juice is applied to wounds and burns } \\
\text { to speed up the healing process }\end{array}$ & $\begin{array}{l}\text { Arnold and Gulumian } \\
\text { (1984); Mabona et al. (2013) }\end{array}$ \\
\hline $\begin{array}{l}\text { Salvia stenophylla Burch. ex } \\
\text { Benth }\end{array}$ & Blue mountain sage & Lamiaceae & $\begin{array}{l}\text { Leaves are used to soothe digestive problems, colds, } \\
\text { coughs, chest congestion and to relieve breathing issues }\end{array}$ & $\begin{array}{l}\text { A poultice of the leaves are used for wounds and } \\
\text { sores }\end{array}$ & Kamatou et al. (2005) \\
\hline $\begin{array}{l}\text { Sansevieria hyacinthoides }(\mathrm{L} .) \\
\text { Druce }\end{array}$ & Devil's tongue, Snake tongue & Asparagaceae & $\begin{array}{l}\text { The leaves are used to treat ear infections, toothache, } \\
\text { haemorrhoids, ulcers, intestinal worms, stomach disorders } \\
\text { and diarrhoea }\end{array}$ & $\begin{array}{l}\text { Leaf decoctions are used topically for burns, } \\
\text { wounds and swellings }\end{array}$ & $\begin{array}{l}\text { Ribeiro et al. (2010); Watt } \\
\text { and Breyer (1962) }\end{array}$ \\
\hline Scadoxus puniceus (L.) Friis \& & Snake lily, Rooikwas (Afr.), & Amaryllidaceae & Bulbs and roots are used to treat coughs, gastro-intestinal & Leaves are applied to sores and ulcers to aid & Watt and Breyer (1962); Van \\
\hline
\end{tabular}




\begin{tabular}{|c|c|c|c|c|c|}
\hline Nordal & & & problems, febrile colds, asthma, leprosy, sprains and bruises & healing and act as an antiseptic & Wyk et al. (2000) \\
\hline Schinziophyton rautanenii Schinz & Mongongo tree & Euphorbiaceae & The aerial plant part is used for skin diseases & $\begin{array}{l}\text { The seed oil is used as a skin cleanser and } \\
\text { moisturizer }\end{array}$ & $\begin{array}{l}\text { Juliani et al. (2007); } \\
\text { Vermaak et al. (2011) }\end{array}$ \\
\hline Scilla natalensis Planch. & $\begin{array}{l}\text { Wild squill, Blouberglelie } \\
\text { (Afr.) }\end{array}$ & Hyacinthaceae & $\begin{array}{l}\text { Ash from burnt plants and bulbs are used in powdered form } \\
\text { to rub on cuts and scratches, over sprains and fractures }\end{array}$ & $\begin{array}{l}\text { Ointments from fresh bulbs are used externally to } \\
\text { treat various skin ailments like boils and sores }\end{array}$ & $\begin{array}{l}\text { Leistner (2000); Frum } \\
(2006)\end{array}$ \\
\hline Sclerocarya birrea Sond. & Marula & Anacardiaceae & Leaves/stem/bark is widely used to treat stomach illnesses & $\begin{array}{l}\text { The leaves are used to treat acne and other skin } \\
\text { conditions }\end{array}$ & $\begin{array}{l}\text { Njume et al. (2011); Eloff } \\
\text { (2001) }\end{array}$ \\
\hline Senecio serratuloides DC.* & $\begin{array}{l}\text { Umaphozisa Umkhuthelo } \\
\text { (Afr.) }\end{array}$ & Asteraceae & $\begin{array}{l}\text { The aerial part of the plant is used to treat internal and } \\
\text { external sores and gonorrhoea }\end{array}$ & $\begin{array}{l}\text { The aerial plant part of the plant is used for sores, } \\
\text { burns and as a blood purifier }\end{array}$ & $\begin{array}{l}\text { van Wyk et al. (2009); Wet et } \\
\text { al. (2012) }\end{array}$ \\
\hline Sesamum indicum $\mathrm{L}$. & Sesame & Pedaliaceae & $\begin{array}{l}\text { Seeds are used for cholera, diarrhoea, dysentery and } \\
\text { respiratory infections }\end{array}$ & Seed powder is used for ulcers and bleeding piles & Kapoor (2001) \\
\hline Sideroxylon inerme L. & $\begin{array}{l}\text { White milkwood, Melkbessie } \\
\text { (Afr.) }\end{array}$ & Sapotaceae & The bark is traditionally used for skin diseases & Bark is widely used as a skin lightener & Van Wyk and Gerick (2000) \\
\hline $\begin{array}{l}\text { Siphonochilus aethiopicus } \\
\text { Schweif.* }\end{array}$ & $\begin{array}{l}\text { Natal ginger, Wildegemmer } \\
\text { (Afr.) }\end{array}$ & Zingiberaceae & $\begin{array}{l}\text { Rhizomes and roots are chewed to treat asthma, hysteria, } \\
\text { colds and coughs }\end{array}$ & Leaf extracts are used for skin depigmentation & $\begin{array}{l}\text { Hutchings (1996); Van Wyk } \\
\text { et al. (1997) }\end{array}$ \\
\hline Solanum incanum $\mathrm{L}$. & Bitter Apple & Solanaceae & $\begin{array}{l}\text { The aerial part of the plant is used as tooth antiseptic and } \\
\text { for toothache }\end{array}$ & $\begin{array}{l}\text { The aerial plant part of the plant is used for } \\
\text { various skin diseases }\end{array}$ & Al-Fatimi et al. (2007) \\
\hline Sutherlandia frutescens (L.) R.Br. & $\begin{array}{l}\text { Cancer bush, } \\
\text { Hoenderbelletjie (Afr.) }\end{array}$ & Fabaceae & $\begin{array}{l}\text { The aerial plant part is used to treat chicken pox, } \\
\text { rheumatoid arthritis, dysentery and inflammation }\end{array}$ & Leaf decoctions are used for washing wounds & $\begin{array}{l}\text { Van Wyk et al. (1997) } \\
\text { Jackson (1990) }\end{array}$ \\
\hline $\begin{array}{l}\text { Tecomaria capensis (Thunb.) } \\
\text { Spach }\end{array}$ & $\begin{array}{l}\text { Cape honeysuckle, } \\
\text { Malangula (Afr.) }\end{array}$ & Bignoniaceae & $\begin{array}{l}\text { Bark infusion is used as an antidiarrheal, to relieve pain, } \\
\text { sleeplessness, and antipyretic }\end{array}$ & Bark infusion is used to treat inflammation & Hutchings et al. (1996) \\
\hline Terminalia sericea Burch. ex DC. & $\begin{array}{l}\text { Silver terminalia, Vaalboom } \\
\text { (Afr.) }\end{array}$ & Combretaceae & $\begin{array}{l}\text { Leaf and root infusion is taken for the treatment of } \\
\text { diarrhoea and stomach aches }\end{array}$ & Leaves are used as an antibiotic for wounds & Van Wyk et al. (1997) \\
\hline Trichilia dregeana Sond. & $\begin{array}{l}\text { Cape mahogany, } \\
\text { rooiessenhout (Afr.) }\end{array}$ & Meliaceae & $\begin{array}{l}\text { The aerial plant part used as a stomach cleanser and to treat } \\
\text { kidney problems, leprosy and sleeplessness }\end{array}$ & The aerial plant part are used as a blood cleanser & $\begin{array}{l}\text { Hutchings et al. (1996); } \\
\text { Pooley (1993) }\end{array}$ \\
\hline
\end{tabular}




\begin{tabular}{|c|c|c|c|c|c|}
\hline Trichilia emetica Vahl. & Natal Mahogany & Meliaceae & $\begin{array}{l}\text { Powder of the grounded roots is used against ascaris } \\
\text { stomachache and dysmenorrhoea }\end{array}$ & $\begin{array}{l}\text { Leaves or fruits are used as poultices for bruises } \\
\text { and eczema }\end{array}$ & $\begin{array}{l}\text { Van Wyk et al. (2011); } \\
\text { Diallo et al. (2003) }\end{array}$ \\
\hline Valeriana capensis Thunb.* & $\begin{array}{l}\text { Cape Valerian, } \\
\text { Wildebalderjan (Afr.) }\end{array}$ & Valerianaceae & $\begin{array}{l}\text { The whole plant is used for asthma, insomnia, hysteria and } \\
\text { nervous disorders }\end{array}$ & Roots are used topically to treat cuts and wounds & $\begin{array}{l}\text { Hutchings (1996); Van Wyk } \\
\text { and Gericke (2000) }\end{array}$ \\
\hline $\begin{array}{l}\text { Vernonia natalensis Sch.Bip. ex } \\
\text { Walp* }\end{array}$ & $\begin{array}{l}\text { Silver Vernonia, } \\
\text { Ihlambihloshana (Afr.) }\end{array}$ & Asteraceae & $\begin{array}{l}\text { The whole plant is used to treat malaria and for pain and } \\
\text { kidneys }\end{array}$ & Root/leaf decoctions are used to treat boils & $\begin{array}{l}\text { Hutchings (1996); Van Wyk } \\
\text { and Gericke (2000) }\end{array}$ \\
\hline Viscum capense L.f.* & $\begin{array}{l}\text { Cape mistle toe, Lidjiestee } \\
\text { (Afr.) }\end{array}$ & Viscaceae & $\begin{array}{l}\text { The whole plant is used to treat epilepsy, asthma, bronchitis } \\
\text { and warts }\end{array}$ & $\begin{array}{l}\text { Whole plant is applied externally to treat warts } \\
\text { and other skin disorders }\end{array}$ & Watt and Breyer (1962) \\
\hline $\begin{array}{l}\text { Warburgia salutaris (Bertol. f.) } \\
\text { Chiov. }\end{array}$ & $\begin{array}{l}\text { Pepper-bark tree, } \\
\text { Peperbasboom (Afr.) }\end{array}$ & Canellaceae & $\begin{array}{l}\text { Bark decoctions are used in abdominal pains, constipation, } \\
\text { diarrhoea, irritation, pneumonia, blood disorders, } \\
\text { rheumatism and snake bite }\end{array}$ & $\begin{array}{l}\text { Leaf and stalk lotion is used to treat sores and } \\
\text { skin irritations }\end{array}$ & $\begin{array}{l}\text { Hutchings (1996); Maroyi } \\
\text { (2013) }\end{array}$ \\
\hline Watsonia tabularis $\mathrm{L} . *$ & Bugle lily & Iridaceae & Corms are used to treat diarrhoea & Corms are used for inflammation & Hutchings et al (1996) \\
\hline Withania somnifera $\mathrm{L}$. & $\begin{array}{l}\text { Winter cherry, Koorshout } \\
\text { (Afr.) }\end{array}$ & Solanaceae & $\begin{array}{l}\text { Leaf decoction, infusion or tincture are applied for } \\
\text { inflammation, haemorrhoids, rheumatism }\end{array}$ & $\begin{array}{l}\text { Leaves are used to heal open as well as septic } \\
\text { and inflamed wounds }\end{array}$ & Van Wyk et al. (1997) \\
\hline Ximenia americana $\mathrm{L}$. & False sandalwood & Olacaceae & $\begin{array}{l}\text { Stem bark is used to treat fever, stiffness, sore throats, } \\
\text { asthma, headaches, abdominal pains, dysentery, inflamed } \\
\text { joints and mouth ulcers }\end{array}$ & $\begin{array}{l}\text { Crushed roots and sap are applied to rashes, } \\
\text { ringworm and skin ulcers }\end{array}$ & $\begin{array}{l}\text { Maikai et al. (2007); } \\
\text { Ogunleye and Ibitoye (2003) }\end{array}$ \\
\hline $\begin{array}{l}\text { Xysmalobium undulatum (L.) } \\
\text { Aiton } \mathrm{f} .\end{array}$ & Milk bush, Melkbos (Afr.) & Apocynaceae & $\begin{array}{l}\text { The entire plant part is widely used as an anti-diarrhoeal, to } \\
\text { treat malaria, typhoid fever and skin diseases }\end{array}$ & $\begin{array}{l}\text { Powdered root is used to treat wounds and } \\
\text { abscesses }\end{array}$ & $\begin{array}{l}\text { Watt (1935); Van Wyk et al. } \\
\text { (1997) }\end{array}$ \\
\hline Zantedeschia aethiopica Spreng.* & $\begin{array}{l}\text { White arum lily, Wit varkoor } \\
\text { (Afr.) }\end{array}$ & Araceae & $\begin{array}{l}\text { Fresh leaves and rhizomes are used for the treatment of } \\
\text { headaches }\end{array}$ & $\begin{array}{l}\text { Leaves are applied directly to the skin to treat } \\
\text { wounds, boils and sores }\end{array}$ & Watt and Breyer (1962) \\
\hline Ziziphus mucronata Willd & $\begin{array}{l}\text { Buffalo thorn, Blinkblaar- } \\
\text { wag-n-bietjie (Afr.) }\end{array}$ & Rhamnaceae & $\begin{array}{l}\text { Bark and roots decoctions are used to treat snake bite, body } \\
\text { pains, respiratory infections, chest problems, } \\
\text { gastrointestinal complaints, diarrhoea and dysentery }\end{array}$ & $\begin{array}{l}\text { Leaf/root/bark decoctions are applied to treat } \\
\text { boils, sores and swellings }\end{array}$ & $\begin{array}{l}\text { Watt and Breyer (1962); Van } \\
\text { Wyk et al. (2000); Van Wyk } \\
\text { et al. (2011) }\end{array}$ \\
\hline
\end{tabular}

*Scientific validation of the ethnobotanical and cosmeceutical usage required. No scientific pharmacological data available in the literature. 


\section{Activities attributed to skin-care ethnobotanicals}

In accordance with the ethnobotanical studies, the selected 117 plant species grown in South Africa are used traditionally for the treatment of several ailments including various skin disorders. They showed activities like wound healing, antioxidant, anti-inflammatory and anti-tyrosinase activities which are directly associated with skin care. Table 2 depicts the pharmacological properties of species associated with treating skin conditions and toxicological relevance, which are explored scientifically but do require further explorations.

\subsection{Antioxidant activity}

Free radical formation is controlled naturally by various beneficial compounds known as antioxidants. Antioxidants are radical scavengers which provide protection to the human body against free radicals by inhibiting various oxidizing chain reactions. Reactive oxygen species (ROS) generated exogenously react with various biomolecules present in the skin and play important role in skin disorders (Yamakoshi et al., 2003; Singh and Agarwal, 2009). Ultraviolet radiation from sunlight is the most common exogenous factor and is harmful to the skin. The continuous exposure to various environmental factors lead to alterations in the connective tissue due to the formation of lipid peroxides, enzymes and reactive oxygen species, which results in various skin disorders (Kaur et al., 2006).

Plant extracts contain numerous naturally occurring compounds which are useful as antioxidants, range from alpha tocopherol and beta carotene to phenolic compounds (Mohamed et al., 2006). Natural antioxidants are effective in preventing free radical formation by scavenging them or promoting their decomposition and suppressing disorders. Some compounds inhibit the initiation or propagation of oxidative chain reactions, thus preventing or repairing oxidative damage done to the body's cells by oxygen (Velioglu et al., 1998). Antioxidants derived from natural sources have attracted much interest in herbal preparations for skin disorders. Most of the species listed in Table 2 exhibited good antioxidant activity in various assays. 


\subsection{Anti-inflammatory activity}

Many environmental factors cause injuries and inflammation of the skin, especially sun light is an important factor for skin disorders such as skin cancer (Katiyar, 2005). Highly reactive oxygen species produced by several enzymatic and non-enzymatic mechanisms in the skin, due to the effect of sunburn. Skin inflammation is either acute or chronic. Acute inflammation results from exposure to UV radiation or from contact with chemical irritants while chronic inflammation results from a sustained immune cell mediated inflammatory response within the skin itself. Typical clinical signs of inflammation include redness, heat and swelling which are due to vascular alterations in the area of injury (Safayhi et al., 1992). This inflammation is long lasting and can cause significant and serious tissue destruction. A number of nuclear transcription factors are responsible for many of the regulatory functions of the inflammatory response such as interleukin-1 (IL-1), interleukin-2 (IL-2), interleukin-6 (IL-6), interleukin-8 (IL-8) and tumour necrosis factor (TNF- $\alpha$ ).

The structural and functional diversity of phytochemicals showed unique opportunities for the development of chemotherapeutic agents for many inflammatory targets. Flavonoids such as quercetin have been shown to inhibit both phospholipase A2 and lipoxygenase enzymes which results in the inhibition of pro-inflammatory prostaglandins and leukotrienes. Many ethnobotanicals have a history of traditional use for the treatment of inflammation. A few taxa listed in Table 2, have been evaluated for anti-inflammatory activity and some of these showed good activity in various assays.

\subsection{Anti-tyrosinase activity}

Melanin is a pigment that is responsible for the colour of eyes, hair and skin in humans. The pigment is secreted and produced, through a physiological process called melanogenesis, by the melanocytes cells, which are distributed in the basal layer of the dermis. There are two types of melanin pigments that can be produced by the melanocyte cells, eumelanin which is black or brown, and pheomelanin which is red or yellow and 
alkaline soluble. The colour of human skin and hair is determined by the type and distribution of melanin pigment. Each individual of the different racial groups have more or less the same number of melanocyte cells, thus the type of melanin produced depends on the functioning of the melanocytes i.e. people with darker skin are genetically programmed to constantly produce higher levels of melanin (Mapunya et al., 2011). It is formed through a series of oxidative reactions involving the amino acid tyrosine in the presence of the enzyme tyrosinase, the key enzyme in melanin biosynthesis (Halder et al., 2004).

The role of melanin is to protect the skin against UV light damage by absorbing UV sunlight and removing the reactive oxygen species. Over-activity of tyrosinase, the key enzyme in melanin biosynthesis, leads to the overproduction of melanin. There are several noteworthy tyrosinase inhibitors obtained from natural sources reported in literature which are used for depigmentation or for the disorder of hyperpigmentation of the skin. There is a variety of plant species that are used traditionally for the treatment of different skin problems. Different parts of these particular plants have been powdered and are used as face masks to remove spots and have also been used for skin lightening purposes. A few taxa listed in Table 2, have been evaluated for the anti-tyrosinase activity and some of these have showed good anti-tyrosinase activity. Further research on the promising plants in clinical studies will be required in order to prove their potential for skin-care formulations.

\subsection{Wound treatment}

Wounds are physical injuries which result from the opening or breaking of the skin that may cause disturbances in the normal skin anatomy and function. Wounds may also be produced by chemical, thermal, microbial or immunological assault on the skin tissue. The cellular and biochemical complex involved in treating wounds is a process of structural and functional integrity with the recovery of strength of the injured tissue. Although wound healing is a natural process that has the ability to heal on its own, for rapid healing there is a need for proper treatment for damaged tissue (Rupesh et al., 2011). 
Many formulations/plant extracts/plant-derived compounds are being used for wound treatment. For example lotion made from the infusion of Calendula officinalis flowers in olive oil is used for skin regeneration, sunburn, bed sores and other inflammatory conditions. A preparation made from Rosemary and Calendula sold with the name "Paul Penders Rosemary and Calendula Cleansing Milkwork" are effective in removing surface dirt and impurities form skin. Another cream made form 22 herbs including Calendula with the trade name "LevensESSENTIE Gold ${ }^{\circledR}$ " is used for soft and remarkably clear skin. "Kaircin" is a natural antioxidant cream made from Crocus Sativus under the brand name "Mother Herbs" helps to nourish skin, removes imperfections and acts against the ageing due to its antioxidant properties. Oil made from Eriocephalus punctulatus available as "Cape Camomile" contains significant amount of azulene, a known anti-inflammatory agent. Another preparation "Derma Gel Treatment" made from Aloe ferox, Eriocephalus punctulatus and Lippia javanica are used for the Soothing, hydrating and purifying all skin types. "Sausage Tree Cream" made from Africana Kigelia, is specially formulated for the treatment of skin cancer (Solar Keratoses), also effective in the treatment of psoriasis, eczema and other skin irritations. "Blue Mountain Sage" is an aromatherapy essential oil made from leaves of Salvia stenophylla by traditional South African methods are used to treat various skin ailments. "Elemis Maximum Moisture Day Cream”, “African Botanics Pure Marula Oil” and Dr Jackson's Face Oil contains Sclerocarya birrea as an ingredient, claims to protect skin from cold weather, improve elasticity and reduce redness and fine lines. A formulation made by South African company from the taxa Aspalathus linearis under the trade name Annique ${ }^{\circledR}$, claims retaining the beauty and vitality of skin. Annique ${ }^{\circledR}$ Products are the triple gold winner of the International Inventions Exhibition in Geneva; promote the repair mechanisms in a natural way (Kumar et al., 2007). Plant based materials are used as first aid-antiseptic coagulants and for the purpose of wound washing by South African peoples at various localities. Almost all the plants discussed in this paper are used for the treatment of wounds. 
There is a possibility that some of those mentioned in table 1 and table 2 may lead to the finding of novel formulations with wound healing activity.

\section{Scientifically explored plants: further exploration needed}

Most of the plant species in South Africa which are used in herbal preparation for skin care and need further attention are listed in Table 2. These plants exhibited promising activities associated with skin ailments. Crude extracts from all the plant species which are evaluated for antioxidant, anti-inflammatory, anti-tyrosinase and wound healing activities, showed good activity in various bioassays. However, only limited scientific information has been reported for some of the species while for others no activity has been reported. Most of these species are indigenous to South Africa except, for a few that are cultivated.

There are 35 species out of the 117 which are totally unexplored, but are frequently used in the traditional system by various communities in South Africa. Therefore, these plant species need to be studied with priority. Additionally, the pharmacological properties of plant species namely, Aloe aculeata, Aloe arborescens, Aloe ferox, Aloe pretoriensis, Aloe sessiliflora, Aloe vera, Artemisia afra, Calodendrum capense, Greyia flanaganii, Harpephyllum caffrum, Hyaenanche globosa, Leucosidea sericea, Sclerocarya birrea, Sideroxylon inerme and Ximenia americana have been explored scientifically by our research group for skin hyperpigmentation problems. All plant species were investigated for their effect on tyrosinase using both L-tyrosine and L-DOPA as substrates by the standard methods (Momtaz et al., 2010; Mapunya et al. 2011; More et al., 2012). Kojic acid was used as a control drug. Final concentrations of the extract samples ranged from 3.91-500 $\mu \mathrm{g} / \mathrm{ml}$ and Kojic acid (positive control) ranged from 3.125-400 $\mu \mathrm{g} / \mathrm{ml}$ respectively. Antioxidant activities of these species and purified compounds were investigated using the 1,2-diphenyl-2picrylhydrazyl (DPPH) antioxidant assay. The inhibition of tyrosinase activity relative to the inhibition of its activity at the transcriptional level was also studied by the determination of the degree of expression of mRNAs for this gene by using extract of Sideroxylon inerme- 
treated cells (B16F10) and semi-quantitative RT-PCR. The taxa Sclerocarya birrea, Greyia flanaganii and Sideroxylon inerme, which showed good anti-tyrosinase activity were explored further for other pharmacological properties and for the identification of bioactive compounds.

These results i.e. significant tyrosinase inhibition activity, antioxidant, antibacterial activity and low toxicity as well as the presence of active phytoconstituents provides in vitro evidence that these plants may have strong potential for their usage for skin care. An additional five species have recently exhibited excellent pharmacological and cosmetic relevance in different bioassays (unpublished result) and are under clinical trials for skin hyperpigmentation and for the evaluation of their sun-protection factor.

Based on scientific data, species such as Greyia flanaganii (Greyiaceae), Halleria lucida (Scrophulariaceae), Athrixia phylicoides (Asteraceae), Leucosidea sericea (Rosaceae), Trichilia emetica (Meliaceae), Warburgia salutaris (Canellaceae), Bauhinia species (Fabaceae), Crinum moorei (Amaryllidaceae), Harpephyllum caffrum (Anacardiaceae), Leonotis leonurus (Lamiaceae), Melianthus species (Melianthaceae), Mentha longifolia (Lamiaceae), Pelargonium cucullatum (Geraniaceae), Ziziphus mucronata (Rhamnaceae) etc. showed promising and significant pharmacological activities, hence it should be worth exploring the potential of these plants in clinical studies which can be very helpful to take these plants to possible product level. A number of species such as African oil palm (Elaeis guineensis), Baobab (Adansonia digitata), Bitter Aloe (Aloe ferox), Blue Mountainsage (Salvia stenophylla), Cape Camomile (Eriocephalus punctulatus), Cape Mahogany (Trichilia emetica) False Sandalwood (Ximenia Americana), Kei Bottle Brush (Greyia flanaganii), Linseed oil (Linum usitatissimum), Manketti Tree (Schinziophyton rautanenii), Marula (Sclerocarya birrea), Rooibos Tea (Aspalathus linearis), Sesame oil (Sesamum indicum), White Milk Wood (Sideroxylon inerme), Wild Rosemary (Eriocephalus africanus), Wild Watermelon (Citrullus lanatus), Honeybush tea (Cyclopia intermedia) etc. are already one of 
the ingredients of the skin care products. It will be worth exploring various relevant pharmacological activities such as antioxidant, anti-inflammatory, anti tyrosinase and wound healing activity in order to substantiate the potential usage of these products.

The toxicity of a number of species species as mentioned in table 2 such as Aloe arborescens (Aloaceae), Artemisia afra (Asteraceae), Bauhinia species (Fabaceae), Harpephyllum caffrum (Anacardiaceae), Leucosidea sericea (Rosaceae), Sclerocarya birrea (Anacardiaceae) etc. should be researched with caution as moderate toxicity was already observed in toxicity analysis conducted previously. One can conduct further additional different toxicity analysis of these plants before considering them for potential product development. The particular constituents responsible for the toxicity of the species needs to be identified. In addition, the target tissue (s) and mechanism (s) of toxicity deserve further investigations.

\section{Scientifically unexplored plants: specific research needs}

Almost 35 plant species marked as asterisk (*) in table 1 are totally unexplored scientifically with regard to skin care applications. These species are already being used traditionally for treating skin conditions, hence need special attention with regard to exploring for their possible potential for usage for skin care. The taxa should be studied scientifically to investigate their potential for skin care, as these plants have never been explored for antioxidant, anti-inflammatory, anti tyrosinase and wound healing activity. The data provided here in, should help provide a practical base for further scientific research on these species. The chemical and pharmacological properties of these species should be further investigated to understand their traditional use and to identify leading compounds for skincare valuable products. 
Table 2: Relevant pharmacological activities of plants grown in South Africa, which are used for skin care

\begin{tabular}{|c|c|c|c|c|c|}
\hline \multirow[t]{2}{*}{ Plant name } & \multicolumn{3}{|c|}{ Pharmacological studies } & \multirow[t]{2}{*}{ Toxicity } & \multirow[t]{2}{*}{ Reference } \\
\hline & Anti-oxidant activity & Anti-inflammatory activity & Anti-tyrosinase activity & & \\
\hline $\begin{array}{l}\text { Acokanthera } \\
\text { oppositifolia }\end{array}$ & $\begin{array}{l}\text { The methanol extract of stem } \\
\text { ABTS assay: } 99 \% \text { inhibition at } 0.08 \\
\mathrm{mg} / \mathrm{mL} \\
\text { DPPH assay: } 70 \% \text { inhibition at } 0.1 \\
\mathrm{mg} / \mathrm{mL}\end{array}$ & * & * & ** & Adedapo et al. (2008a) \\
\hline Adansonia digitata & $\begin{array}{l}\text { Butanol extract of leaves } \\
\text { FTC assay; } 78 \% \text { inhibition of lipid } \\
\text { peroxidation at } 500 \mu \mathrm{g} / \mathrm{mL}\end{array}$ & $\begin{array}{l}\text { Water extract of fruit pulp } \\
\text { Cytokine analysis: decrease of cytokine IL-8 at } \\
70 \mu \mathrm{g} / \mathrm{mL}\end{array}$ & * & $\begin{array}{l}\text { The methanol leaf extract } \\
\text { MTT toxicity assay: } \mathrm{IC}_{50} ; 70 \mu \mathrm{g} / \mathrm{mL} \text { on Vero } \\
\text { monkey kidney cells }\end{array}$ & $\begin{array}{l}\text { Selvarani and Hudson } \\
\text { (2009); Oloyede et al. (2010) }\end{array}$ \\
\hline Agathosma betulina & $\begin{array}{l}\text { Methanol : dichloromethane (1:1) } \\
\text { extract of leaves } \\
\text { DPPH assay: } \mathrm{IC}_{50} ;>100 \mu \mathrm{g} / \mathrm{mL} \\
\text { ABTS assay: } \mathrm{IC}_{50} ; 37.75 \mu \mathrm{g} / \mathrm{mL}\end{array}$ & $\begin{array}{l}\text { The essential oil of aerial parts } \\
\text { The } 5 \text {-lipoxygenase assay: } \mathrm{IC}_{50} ; 50.37 \mu \mathrm{g} / \mathrm{mL}\end{array}$ & * & $\begin{array}{l}\text { Methanol : Dichloromethane (1:1) extract of } \\
\text { leaves } \\
\text { MTT toxicity assay: } \mathrm{IC}_{50} ; 100 \mu \mathrm{g} / \mathrm{mL} \text { on } \\
\text { Graham cells }\end{array}$ & $\begin{array}{l}\text { Moolla and Viljoen (2008); } \\
\text { Street and Prinsloo (2013) }\end{array}$ \\
\hline Aloe aculeata & * & * & $\begin{array}{l}\text { The ethanol leaf extract } \\
\text { Anti-tyrosinase assay: } 31 \% \\
\text { tyrosinase inhibition at } 500 \mu \mathrm{g} / \mathrm{mL}\end{array}$ & ** & Mapunya et al. (2011) \\
\hline A. arborescens & * & * & NA & $\begin{array}{l}\text { The ethanol leaf extract } \\
\text { MTT toxicity assay: nontoxic up to } 25 \mu \mathrm{g} / \mathrm{mL} \\
\text { on melanocyte cells }\end{array}$ & Mapunya et al. (2011) \\
\hline Aloe ferox & $\begin{array}{l}50 \% \text { methanol extract of the leaves } \\
\text { DPPH assay: } \mathrm{IC}_{50} ; 10.45 \mathrm{mg} / \mathrm{mL}\end{array}$ & $\begin{array}{l}\text { Petroleum ether extract of leaves } \\
\text { Cyclooxygenase assay: } 100 \% \text { COX-1 inhibition } \\
\text { at } 0.25 \mu \mathrm{g} / \mathrm{mL}\end{array}$ & $\begin{array}{l}\text { The ethanol leaf extract } \\
\text { Anti-tyrosinase assay: } 60 \% \\
\text { tyrosinase inhibition at } 500 \mu \mathrm{g} / \mathrm{mL}\end{array}$ & ** & $\begin{array}{l}\text { Kambizi et al. (2007); } \\
\text { Fawole et al. (2010) }\end{array}$ \\
\hline
\end{tabular}




\begin{tabular}{|c|c|c|c|c|c|}
\hline & & $49.3 \% \mathrm{COX}-2$ inhibition at $0.25 \mu \mathrm{g} / \mathrm{mL}$ & & & \\
\hline Aloe greatheadii & $\begin{array}{l}\text { Leaf gel extract (LGE) and 95\% } \\
\text { aqueous ethanol leaf gel extract (ELGE) } \\
\text { ORAC assay: LGE, } 59 \mu \mathrm{mol} \text { of Trolox } \\
\text { equivalent (TE)/g } \\
\text { ELGE, } 83 \mu \mathrm{mol} \text { of TE/g } \\
\text { FRAP assay: LGE; } 2.63 \mu \mathrm{mol} / \mathrm{g} \\
\text { ELGE; } 8.98 \mu \mathrm{mol} \text { of } / \mathrm{g}\end{array}$ & * & * & ** & Botes et al. (2008) \\
\hline Aloe pretoriensis & $*$ & * & $\begin{array}{l}\text { The ethanol leaf extract } \\
\text { Anti-tyrosinase assay: } 17 \% \\
\text { tyrosinase inhibition at } 500 \mu \mathrm{g} / \mathrm{mL}\end{array}$ & ** & Mapunya et al. (2011) \\
\hline Aloe sessiliflora & * & * & $\begin{array}{l}\text { The ethanol leaf extract } \\
\text { Anti-tyrosinase assay: } 13 \% \\
\text { tyrosinase inhibition at } 500 \mu \mathrm{g} / \mathrm{mL}\end{array}$ & ** & Mapunya et al. (2011) \\
\hline Aloe vera & * & * & NA & ** & Mapunya et al. (2011) \\
\hline Artemisia afra & $\begin{array}{l}\text { Ethanol extract of aerial parts DPPH } \\
\text { assay: } \mathrm{IC}_{50} ; 22.2 \mu \mathrm{g} / \mathrm{mL}\end{array}$ & * & * & $\begin{array}{l}\text { The ethanol extract of aerial part } \\
\text { MTT toxicity assay: } \mathrm{IC}_{50} 16.95 \mu \mathrm{g} / \mathrm{mL} \text { on } \\
\text { McCoy fibroblast cell line }\end{array}$ & $\begin{array}{l}\text { Burits et al. (2001); } \\
\text { More et al. (2012) }\end{array}$ \\
\hline Aspalathus linearis & $\begin{array}{l}\text { The ethanol leaf extract } \\
\text { ORAC assay: } 1402 \mu \mathrm{mol} \text { of TE/g }\end{array}$ & $\begin{array}{l}\text { The aqueous extract of tea }(16 \mathrm{mg} / \mathrm{mL}) \\
\text { In vivo analysis in wister rats: after } 4 \text { week SOD } \\
\text { increased }\end{array}$ & $\begin{array}{l}\text { The ethanol leaf extract } \\
\text { Anti-tyrosinase assay: } 7 \% \\
\text { tyrosinase inhibition at } 500 \mu \mathrm{g} / \mathrm{mL}\end{array}$ & $\begin{array}{l}\text { Methanol extract of aerial part } \\
\text { Cytotoxicity of } \mathrm{H}_{2} \mathrm{O}_{2} \text { : no toxicity of } \mathrm{H}_{2} \mathrm{O}_{2} \text { on } \\
\text { mouse leukemic cells at } 11.25 \mathrm{mg} / \mathrm{mL}\end{array}$ & $\begin{array}{l}\text { Momtaz et al. (2008); } \\
\text { Marnewick et al. (2005 \& } \\
\text { 2011) }\end{array}$ \\
\hline Asparagus africanus & * & $\begin{array}{l}\text { Methanol root extract } \\
\text { Rat paw oedema test: } 22.3 \% \text { inhibition of } \\
\text { oedema in mice at dose of } 250 \mathrm{mg} / \mathrm{kg} \text { ( } 44 \% \text { at } \\
500 \mathrm{mg} / \mathrm{kg} \text { ) }\end{array}$ & * & $\begin{array}{l}\text { Aqueous ethanol extract of whole plant } \\
\text { Acute toxicity assay: } \mathrm{LD}_{50} ; 1264.9 \mathrm{mg} / \mathrm{kg} \text { in } \\
\text { Swiss albino mice }\end{array}$ & $\begin{array}{l}\text { Hassan et al. (2012); Hassan } \\
\text { et al. (2008) }\end{array}$ \\
\hline
\end{tabular}




\begin{tabular}{|c|c|c|c|c|c|}
\hline Athrixia phylicoides & $\begin{array}{l}\text { Aqueous extract of aerial part } \\
\text { TEAC assay: TEAC content } 0.269\end{array}$ & $*$ & $*$ & $\begin{array}{l}\text { Water extract of aerial part } \\
\text { Brine shrimp mortality assay: } \mathrm{LC}_{50} ;>1000 \\
\mu \mathrm{g} / \mathrm{mL}\end{array}$ & $\begin{array}{l}\text { Beer et al. (2011); } \\
\text { McGaw et al. (2007); } \\
\text { Joubert et al. (2008) }\end{array}$ \\
\hline Bauhinia bowkeri & $\begin{array}{l}\text { Acidified } 70 \% \text { acetone leaf extract } \\
\text { DPPH assay: } \mathrm{IC}_{50} ; 19.53 \mu \mathrm{g} / \mathrm{mL} \\
\text { ABTS assay: } \mathrm{IC}_{50} ; 14.50 \mu \mathrm{g} / \mathrm{mL}\end{array}$ & $\begin{array}{l}\text { The acetone leaf extract } \\
\text { Cyclooxygenase assay: } 41.70-71.34 \% \text { COX-1 } \\
\text { inhibition; Ranged from } 65-250 \mu \mathrm{g} / \mathrm{mL}\end{array}$ & * & $\begin{array}{l}\text { The acetone extract of leaf } \\
\text { MTT toxicity assay: not toxic up to } 25 \mathrm{mg} / \mathrm{mL} \\
\text { using the Vero African green monkey kidney } \\
\text { cell line }\end{array}$ & Ahmed et al. (2012) \\
\hline Bauhinia petersiana & $\begin{array}{l}\text { Acidified } 70 \% \text { acetone leaf extract } \\
\text { DPPH assay: } \mathrm{IC}_{50} ; 43.29 \mu \mathrm{g} / \mathrm{mL} \\
\text { ABTS assay: } \mathrm{IC}_{50} ; 17.19 \mu \mathrm{g} / \mathrm{mL}\end{array}$ & $\begin{array}{l}\text { The acetone leaf extract } \\
\text { Cyclooxygenase assay: } 41.70-71.34 \% \text { COX-1 } \\
\text { inhibition; Ranged from } 65-250 \mu \mathrm{g} / \mathrm{mL}\end{array}$ & $*$ & $\begin{array}{l}\text { The acetone extract of leaf } \\
\text { MTT toxicity assay: not toxic up to } 25 \mathrm{mg} / \mathrm{mL} \\
\text { using the Vero African green monkey kidney } \\
\text { cell line }\end{array}$ & Ahmed et al. (2012) \\
\hline Bauhinia variegata & $\begin{array}{l}\text { Acidified } 70 \% \text { acetone leaf extract } \\
\text { DPPH assay: } \mathrm{IC}_{50} ; 123.60 \mu \mathrm{g} / \mathrm{mL} \\
\text { ABTS assay: } \mathrm{IC}_{50} ; 9.24 \mu \mathrm{g} / \mathrm{mL}\end{array}$ & $\begin{array}{l}\text { The acetone leaf extract } \\
\text { Cyclooxygenase assay: } 41.70-71.34 \% \text { COX-1 } \\
\text { inhibition; Ranged from } 65-250 \mu \mathrm{g} / \mathrm{mL}\end{array}$ & $*$ & $\begin{array}{l}\text { The acetone extract of leaf } \\
\text { MTT toxicity assay: not toxic up to } 25 \mathrm{mg} / \mathrm{mL} \\
\text { using the Vero African green monkey kidney } \\
\text { cell line }\end{array}$ & $\begin{array}{l}\text { Ahmed et al. (2012); } \\
\text { Sawhney et al. (2011) }\end{array}$ \\
\hline Bulbine frutescens & $\begin{array}{l}\text { The water extract of leaf } \\
\text { DPPH scavenging activity: Ranged from } \\
0.19-0.34 \mathrm{mg} / \mathrm{mL}\end{array}$ & * & $*$ & $* *$ & $\begin{array}{l}\text { Abegaz et al. (2002); } \\
\text { Pather et al. (2011) }\end{array}$ \\
\hline $\begin{array}{l}\text { Calendula } \\
\text { officinalis }\end{array}$ & $\begin{array}{l}\text { Ethyl acetate fraction of methanol } \\
\text { extract of leaves } \\
\text { DPPH assay: } \mathrm{IC}_{50} ; 0.20 \mu \mathrm{g} / \mathrm{mL}\end{array}$ & $\begin{array}{l}\text { Ethyl acetate fraction of methanol extract of } \\
\text { leaves } \\
\text { TPA assay: } 84 \% \text { inhibition of (TPA)-induced } \\
\text { inflammation }(1 \mu \mathrm{g} / \mathrm{ear}) \text { in mice with an } \mathrm{ID}_{50} \\
\text { value of } 0.05-0.20 \mathrm{mg} / \mathrm{ear}\end{array}$ & * & $\begin{array}{l}\text { Aqueous extract of flower } \\
\text { Acute toxicity assay: Nontoxic up to } 5.0 \mathrm{~g} / \mathrm{kg} \text { in } \\
\text { mice }\end{array}$ & Muley et al. (2009) \\
\hline $\begin{array}{l}\text { Calodendrum } \\
\text { capense }\end{array}$ & $*$ & $*$ & NA & * & Mapunya et al. (2011) \\
\hline
\end{tabular}




\begin{tabular}{|c|c|c|c|c|c|}
\hline Carpobrotus edulis & $\begin{array}{l}\text { Aqueous leaf extract } \\
\text { DPPH assay: } \mathrm{IC}_{50} ; 0.018 \mathrm{mg} / \mathrm{mL} \\
\text { ABTS assay: } \mathrm{IC}_{50} ; 0.016 \mathrm{mg} / \mathrm{mL} \\
\text { Ethanol leaf extract } \\
\text { DPPH assay: } \mathrm{IC}_{50} ; 0.022 \mathrm{mg} / \mathrm{mL} \\
\text { ABTS assay: } \mathrm{IC}_{50} ; 0.05 \mathrm{mg} / \mathrm{mL}\end{array}$ & * & * & $* *$ & $\begin{array}{l}\text { Martins et al. (2011); } \\
\text { Omoruyi et al. (2012); } \\
\text { Ibtissem et al. (2012) }\end{array}$ \\
\hline Centella asiatica & $\begin{array}{l}\text { Aqueous leaf extract } \\
\text { DPPH assay: } \mathrm{IC}_{50} ; 31.25 \mu \mathrm{g} / \mathrm{mL}\end{array}$ & $\begin{array}{l}\text { Aqueous extract of aerial part } \\
\text { Rat paw oedema test: } 46.31 \% \text { inhibition of } \\
\text { Oedema at } 100 \mathrm{mg} / \mathrm{kg} \text { dose in rats }\end{array}$ & * & $* *$ & $\begin{array}{l}\text { Rahman et al. (2013); } \\
\text { George et al. (2009); Pittella } \\
\text { et al. (2009) }\end{array}$ \\
\hline $\begin{array}{l}\text { Chenopodium } \\
\text { ambrosioides }\end{array}$ & $\begin{array}{l}\text { The oil from aerial part } \\
\text { ABTS assay: } \mathrm{IC}_{50} ; 3000 \mu \mathrm{g} / \mathrm{mL}\end{array}$ & $\begin{array}{l}\text { The ethanol extract of aerial part Ear-oedema } \\
\text { assay: inhibition of ear oedema at } 1 \% \text { in cream }\end{array}$ & * & $* *$ & $\begin{array}{l}\text { Kumar et al. (2007); } \\
\text { Grassi et al. (2013) }\end{array}$ \\
\hline Citrullus lanatus & $\begin{array}{l}\text { The methanol fruit extract } \\
\text { ABTS assay: } \mathrm{IC}_{50} ; 23 \mathrm{mg} / 100 \mathrm{~g} \mathrm{DPPH} \\
\text { assay: } \mathrm{IC}_{50} ; 32 \mathrm{mg} / 100 \mathrm{~g}\end{array}$ & $\begin{array}{l}\text { Cucurbitacin E (CE) an isolated compound } \\
\text { Cyclooxygenase assay: } \mathrm{IC}_{50} \text { values of } \mathrm{CE} \text { on } \\
\text { COX-1 and COX-2 were } 90 \text { and } 69 \mu \mathrm{M} \text {, } \\
\text { respectively }\end{array}$ & $*$ & $* *$ & $\begin{array}{l}\text { Reddy et al. (2010); } \\
\text { Abdelwahab et al. (2011) }\end{array}$ \\
\hline Clausena anisata & $\begin{array}{l}\text { The essential oil of leaf } \\
\text { BHT assay: } \mathrm{EC}_{50} ; 6.53 \mathrm{mg} / \mathrm{L}\end{array}$ & $\begin{array}{l}\text { The ethanol leaf extract } \\
\text { Mice-paw oedema test: } 71 \% \text { inhibition at } 450 \\
\mathrm{mg} / \mathrm{kg}\end{array}$ & $*$ & $\begin{array}{l}\text { The ethanol leaf extract } \\
\text { Acute toxicity assay: } \mathrm{LD}_{50} ; 393.7 \mathrm{mg} / \mathrm{kg} \text { in } \\
\text { albino rats }\end{array}$ & $\begin{array}{l}\text { Goudoum et al. (2009); Frum } \\
\text { (2006); Okokon et al. (2012) }\end{array}$ \\
\hline Crinum moorei & $\begin{array}{l}\text { The } 50 \% \text { Methanol extract of bulbs } \\
\text { DPPH assay: } \mathrm{IC}_{50} ; 5.06 \mu \mathrm{g} / \mathrm{mL}\end{array}$ & $\begin{array}{l}\text { The } 50 \% \text { Methanol extract of bulbs } \\
\text { Cyclooxygenase assay: } 95.6 \% \text { COX-1 inhibition } \\
\text { at } 21.5 \mu \mathrm{g} / \mathrm{mL} \\
71.6 \% \mathrm{COX}-2 \text { inhibition at } 21.5 \mu \mathrm{g} / \mathrm{mL}\end{array}$ & $*$ & $* *$ & Fawole et al. (2010) \\
\hline Crocus sativus & $\begin{array}{l}\text { Methanol extract of flowers } \\
\text { DPPH assay: } \mathrm{IC}_{50} ; 1 \mathrm{mg} / \mathrm{mL}\end{array}$ & $\begin{array}{l}\text { The ethanol extract of stigma and petals } \\
\text { Xylene-induced ear edema assay: } 20 \% \text { inhibition }\end{array}$ & $\begin{array}{l}\text { Methanol extract of flowers } \\
\text { Anti-tyrosinase assay: } 10.7-28.2 \%\end{array}$ & $\begin{array}{l}\text { The ethanol extract of stigmas } \\
\text { Acute toxicity assay: } \mathrm{LD}_{50} ; 3.4 \mathrm{~g} / \mathrm{kg} \text { in mice }\end{array}$ & Sariri et al. (2011) \\
\hline
\end{tabular}




\begin{tabular}{|c|c|c|c|c|c|}
\hline & & at $0.32 \mathrm{~g} / \mathrm{kg}$ & $\begin{array}{l}\text { tyrosinase inhibition ranged from } \\
50-1000 \mu \mathrm{g} / \mathrm{mL}\end{array}$ & & \\
\hline Cucumis hirsutus & * & $\begin{array}{l}\text { Petroleum ether extract of leaves } \\
\text { Cyclooxygenase assay: } 91.5 \% \text { COX-1 inhibition } \\
\text { at } 250 \mu \mathrm{g} / \mathrm{mL} \\
80.3 \% \mathrm{COX}-2 \text { inhibition at } 250 \mu \mathrm{g} / \mathrm{mL}\end{array}$ & * & ** & Fawole et al. (2009) \\
\hline Cyclopia intermedia & $\begin{array}{l}\text { Ethanol/Acetone extract of processed } \\
\text { tea } \\
\text { TBARS assay: } 63 \% \text { inhibition of lipid } \\
\text { peroxidation nmol MDA/mg protein: } \\
3.50\end{array}$ & * & * & $\begin{array}{l}\text { Aqueous leaf extract } \\
\text { Salmonella typhimurium assay: reduced } \\
\text { mutagenesis significantly at } 5 \%\end{array}$ & McKay and Blumberg (2007) \\
\hline Datura stramonium & $\begin{array}{l}\text { Aqueous/methanol fruits extract DPPH } \\
\text { assay: } \mathrm{IC}_{50} ;>100 \mathrm{ppm}\end{array}$ & $\begin{array}{l}\text { Aqueous and methanol extract of leaf and fruit } \\
\text { The 5-lipoxygenase assay: } \mathrm{IC}_{50} ;>100 \mathrm{ppm}\end{array}$ & * & ** & $\begin{array}{l}\text { Kumar et al. (2008); } \\
\text { Frum (2006) }\end{array}$ \\
\hline Dicoma anomala & NA & * & * & ** & Steenkamp et al. (2004) \\
\hline Diospyros lycioides & * & $\begin{array}{l}\text { The ethanol leaf extract } \\
\text { Cyclooxygenase assay: } 90 \% \text { COX-1 inhibition at } \\
250 \mu \mathrm{g} / \mathrm{mL} \\
72 \% \mathrm{COX}-2 \text { inhibition at } 250 \mu \mathrm{g} / \mathrm{mL}\end{array}$ & * & $* *$ & Fawole et al. (2009) \\
\hline $\begin{array}{l}\text { Diospyros } \\
\text { mespiliformis }\end{array}$ & $\begin{array}{l}\text { Methanol fruits extract } \\
\text { ABTS assay: } 157.50 \mu \mathrm{mol} / 100 \mathrm{~g}\end{array}$ & * & * & ** & Lamien-Meda et al. (2008) \\
\hline Elaeis guineensis & $\begin{array}{l}\text { Methanol, water and acetone extract of } \\
\text { ripe fruits } \\
\text { DPPH scavenging activity: Ranged from } \\
4.41 \text { to } 6.05 \mathrm{~g} / \mathrm{L}\end{array}$ & * & * & ** & $\begin{array}{l}\text { Neo et al. (2008); } \\
\text { Sasidharan et al. (2010) }\end{array}$ \\
\hline
\end{tabular}




\begin{tabular}{|c|c|c|c|c|c|}
\hline $\begin{array}{l}\text { Elephantorrhiza } \\
\text { elephantine }\end{array}$ & $*$ & $\begin{array}{l}\text { Aqueous root extract } \\
\text { Rat oedema assay: } 93.7 \% \text { inhibition at } 50 \mathrm{mg} / \mathrm{kg}\end{array}$ & * & $\begin{array}{l}\text { Water extract of root } \\
\text { Acute toxicity assay: Nontoxic in rats up to } \\
1600 \mathrm{mg} / \mathrm{kg} \text { body weight }\end{array}$ & Maphosa et al. (2009) \\
\hline $\begin{array}{l}\text { Eriocephalus } \\
\text { africanus }\end{array}$ & $\begin{array}{l}\text { Acetone leaf extract } \\
\text { DPPH assay: } \mathrm{IC}_{50} ; 47.2 \mu \mathrm{g} / \mathrm{mL}\end{array}$ & $\begin{array}{l}\text { Essential oil of aerial part } \\
\text { The 5-lipoxygenase assay: } 5 \text {-LOX } \mathrm{IC}_{50} ; 32.8 \\
\mu \mathrm{g} / \mathrm{mL}\end{array}$ & * & $* *$ & Njenga and Viljoen (2006) \\
\hline $\begin{array}{l}\text { Eriocephalus } \\
\text { punctulatus }\end{array}$ & $\begin{array}{l}\text { Acetone extract of leaf displayed DPPH } \\
\text { scavenging activity ranged from } 21.5 \text { to } \\
79 \mu \mathrm{g} / \mathrm{mL}\end{array}$ & $\begin{array}{l}\text { Essential oil of aerial part } \\
\text { The 5-lipoxygenase assay: 5-LOX IC } \mathrm{C}_{50} ; 62 \\
\mu \mathrm{g} / \mathrm{mL}\end{array}$ & * & ** & Njenga and Viljoen (2006) \\
\hline Erythrina lysistemon & $\begin{array}{l}\text { The leaf methanol extract } \\
\text { DPPH assay: } \mathrm{IC}_{50} ; 86 \mu \mathrm{g} / \mathrm{mL}\end{array}$ & $\begin{array}{l}\text { Ethanol and ethyl acetate extract } \\
\text { Cyclooxygenase assay: } 78-98 \% \text { COX-1 } \\
\text { inhibition at } 500 \mu \mathrm{g} / \mathrm{mL}\end{array}$ & * & ** & $\begin{array}{l}\text { Juma and Majinda (2005); } \\
\text { Pillay et al. (2001) }\end{array}$ \\
\hline $\begin{array}{l}\text { Eucalyptus } \\
\text { camaldulensis }\end{array}$ & $\begin{array}{l}\text { The essential oil from aerial part DPPH } \\
\text { scavenging activity: Ranged from } 1.75 \text { - } \\
12.62 \mathrm{mg} / \mathrm{mL}\end{array}$ & $*$ & $*$ & $* *$ & $\begin{array}{l}\text { Siramon and Ohtani (2007); } \\
\text { Miguel (2010) }\end{array}$ \\
\hline Foeniculum vulgare & $\begin{array}{l}\text { The water and ethanol seed extracts } \\
\text { DPPH assay: water and methanol } \\
\text { extract; } 47.49 \% \text { and } 36.46 \% \text { of decrease } \\
\text { of DPPH at } 250 \mu \mathrm{g} \text {, respectively }\end{array}$ & * & * & $* *$ & $\begin{array}{l}\text { Adhikari et al. (2008); } \\
\text { Oktay et al. (2003) }\end{array}$ \\
\hline Greyia flanaganii & $\begin{array}{l}\text { Leaf ethanol extract } \\
\text { DPPH assay: } \mathrm{IC}_{50} ; 22.01 \mu \mathrm{g} / \mathrm{mL}\end{array}$ & * & $\begin{array}{l}\text { The ethanol leaf extract } \\
\text { Anti-tyrosinase assay: } \mathrm{IC}_{50} ; 32.62 \\
\mu \mathrm{g} / \mathrm{mL} \text { using L-tyrosine as substrate }\end{array}$ & $\begin{array}{l}\text { The ethanol leaf extract } \\
\text { XTT assay: } \mathrm{IC}_{50} ; \geq 400 \mu \mathrm{g} / \mathrm{mL}\end{array}$ & Mapunya et al. (2011) \\
\hline Gunnera perpensa & $\begin{array}{l}\text { The methanol rhizome extract DPPH } \\
\text { assay: } \mathrm{IC}_{50} ; 16 \mathrm{mg} / \mathrm{L}\end{array}$ & $\begin{array}{l}\text { Aqueous extract of rhizome inhibited } \\
\text { Oedema assay: } 59.2 \% \text { inhibition at } 150 \mathrm{mg} / \mathrm{kg}\end{array}$ & * & $\begin{array}{l}\text { The methanol extract of rhizome } \\
\text { Brine shrimp lethality test: } \mathrm{LC}_{50} ; 137.62 \\
\mathrm{mg} / \mathrm{mL}\end{array}$ & $\begin{array}{l}\text { Simelane et al. (2010); } \\
\text { Nkomo et al. (2010) }\end{array}$ \\
\hline
\end{tabular}




\begin{tabular}{|c|c|c|c|c|c|}
\hline Halleria lucida & $\begin{array}{l}\text { The methanol leaf extract } \\
\text { DPPH assay: } \mathrm{IC}_{50} ; 8.49 \mu \mathrm{g} / \mathrm{mL}\end{array}$ & * & * & *** & $\begin{array}{l}\text { Adedapo et al. (2008b); Frum } \\
\text { et al. (2007) }\end{array}$ \\
\hline $\begin{array}{l}\text { Harpagophytum } \\
\text { procumbens }\end{array}$ & $\begin{array}{l}\text { The ethanol root extract } \\
\text { FRAT assay: } 47.87 \% \text { inhibition at } 200 \\
\mu \mathrm{g} / \mathrm{mL}\end{array}$ & $\begin{array}{l}\text { An aqueous extract of root } \\
\text { Paw-edema test in rats: reduction from } 7.6 \mathrm{~mm} \text { to } \\
6.6 \mathrm{~mm} \text { at } 800 \mathrm{mg} / \mathrm{kg} \text { dose for } 3 \text { days }\end{array}$ & * & $\begin{array}{l}\text { The ethanol root extract } \\
\text { Acute toxicity assay: } \mathrm{LD}_{50} ; 13.5 \mathrm{~g} / \mathrm{kg} \text { body } \\
\text { weight }\end{array}$ & $\begin{array}{l}\text { Georgiev et al. (2012); } \\
\text { Brien et al. (2006) }\end{array}$ \\
\hline $\begin{array}{l}\text { Harpephyllum } \\
\text { caffrum }\end{array}$ & $\begin{array}{l}\text { The methanol and dichloromethane } \\
\text { extract of stem bark } \\
\text { DPPH scavenging activity: Ranged from } \\
4.26 \text { to } 6.92 \mu \mathrm{g} / \mathrm{mL}\end{array}$ & * & * & $\begin{array}{l}\text { Water-methanol (1:3) leaf extract } \\
\text { MTT toxicity assay: } \mathrm{LC}_{50} ; 50 \mu \mathrm{g} / \mathrm{mL} \text { on human } \\
\text { keratinocyte cells }\end{array}$ & Moyo et al. (2010) \\
\hline $\begin{array}{l}\text { Hyaenanche } \\
\text { globosa }\end{array}$ & $\begin{array}{l}\text { The fruits ethanol extract (F.E.) } \\
\text { TBARS assay: mean value obtained } \\
170.7 \mu \mathrm{mol} / \mathrm{L} \text { in treated 'Hela' cells by } \\
\text { F.E. }\end{array}$ & * & $\begin{array}{l}\text { Ethanol extract of fruit, leaves and } \\
\text { root } \\
\text { Anti-tyrosinase assay: fruit extract; } \\
90.4 \% \text { tyrosinase inhibition at } 200 \\
\mu \mathrm{g} / \mathrm{mL} \\
\text { Leaf extract; } 87 \% \text { tyrosinase } \\
\text { inhibition at } 200 \mu \mathrm{g} / \mathrm{mL} \\
\text { Root extract; } 86.8 \% \text { tyrosinase } \\
\text { inhibition at } 200 \mu \mathrm{g} / \mathrm{mL}\end{array}$ & $\begin{array}{l}\text { The ethanol fruit extract } \\
\text { MTT assay: } \mathrm{IC}_{50} ; 37.7 \mu \mathrm{g} / \mathrm{mL} \text { using the HeLa } \\
\text { cells }\end{array}$ & Momtaz et al. (2010) \\
\hline $\begin{array}{l}\text { Hypericum } \\
\text { perforatum }\end{array}$ & $\begin{array}{l}\text { The ethanol extract of aerial part DPPH } \\
\text { assay: } \mathrm{IC}_{50} ; 21 \mu \mathrm{g} \mathrm{dwb} / \mathrm{mL}\end{array}$ & $\begin{array}{l}\text { Ethanol extract of aerial part } \\
\text { Rat paw oedema assay: } \mathrm{ED}_{50} ; 47.55 \mathrm{mg} / \mathrm{kg}\end{array}$ & $*$ & ** & $\begin{array}{l}\text { Savikin et al. (2007); } \\
\text { Silva et al. (2005) }\end{array}$ \\
\hline Kigelia africana & $\begin{array}{l}\text { The water extract of leaf } \\
\text { TBARS assay: } 0.67 \mathrm{mg} / \mathrm{mL}\end{array}$ & $\begin{array}{l}\text { The stem bark ethanol extract } \\
\text { Paw-oedema assay: } 90 \% \text { inhibition of oedema at } \\
200 \mathrm{mg} / \mathrm{kg} \text { dose after } 6 \mathrm{~h}\end{array}$ & * & $\begin{array}{l}\text { The methanol leaf extract } \\
\text { Acute toxicity test: safe up to dose of } 3000 \\
\mathrm{mg} / \mathrm{kg} \text { in swiss albino mice }\end{array}$ & $\begin{array}{l}\text { Jackson et al. (2000); Picerno } \\
\text { et al. (2005); Olalye \& Rocha } \\
\text { (2007) }\end{array}$ \\
\hline Leonotis leonurus & $\begin{array}{l}\text { Aqueous extract from leaves } \\
\text { DPPH assay: } \mathrm{IC}_{50} ; 34.21 \mathrm{ppm}\end{array}$ & $\begin{array}{l}\text { The methanol extract of leaves } \\
\text { The } 5 \text {-lipoxygenase assay: } \mathrm{IC}_{50} ;>100 \mathrm{ppm}\end{array}$ & * & ** & Frum (2006) \\
\hline
\end{tabular}




\begin{tabular}{|c|c|c|c|c|c|}
\hline Leucosidea sericea & $\begin{array}{l}\text { The ethanol leaf extract } \\
\text { DPPH assay: } \mathrm{IC}_{50} ; 2.01 \mu \mathrm{g} / \mathrm{mL}\end{array}$ & $\begin{array}{l}\text { Petroleum ether extract of leaves } \\
\text { Cyclooxygenase assay: } \mathrm{IC}_{50} ; 0.06 \text { and } 12.66 \\
\mu \mathrm{g} / \mathrm{mL} \text { for COX-1 and COX-2 }\end{array}$ & * & $\begin{array}{l}\text { The ethanol leaf extract } \\
\text { In vitro cytotoxicity assay: } \mathrm{EC}_{50} ; 55.50 \mu \mathrm{g} / \mathrm{mL} \\
\text { in B16-F10 mouse melanocytes }\end{array}$ & $\begin{array}{l}\text { Sharma et al. (2013); Aremu } \\
\text { et al. (2010) }\end{array}$ \\
\hline Lippia javanica & $\begin{array}{l}\text { The ethyl acetate leaf extract ORAC } \\
\text { assay: } 908.00 \mu \mathrm{M} \mathrm{TE} / 10 \mathrm{mg}\end{array}$ & $\begin{array}{l}\text { The aqueous leaf extract } \\
\text { The 5-lipoxygenase assay: } \mathrm{IC}_{50} ;>100 \mathrm{ppm}\end{array}$ & * & ** & $\begin{array}{l}\text { Olivier et al. (2010); } \\
\text { Pretorius (2010); Frum } \\
\text { (2006) }\end{array}$ \\
\hline Malva parviflora & $\begin{array}{l}\text { The methanol leaves extract } \\
\text { ABTS assay: } 84 \% \text { inhibition at } 0.2 \\
\mathrm{mg} / \mathrm{mL}\end{array}$ & * & * & ** & $\begin{array}{l}\text { Adedapo and Ofuegbe } \\
\text { (2013); Farhan et al. (2012) }\end{array}$ \\
\hline Melianthus comosus & $\begin{array}{l}\text { The methanol extract of leaves } \\
\text { DPPH assay: } \text { IC }_{50} ; 5.60 \mathrm{ppm}\end{array}$ & $\begin{array}{l}\text { The methanol extract of leaf } \\
\text { The } 5 \text {-lipoxygenase assay: } \mathrm{IC}_{50} ; 55.05 \mathrm{ppm}\end{array}$ & $*$ & ** & Frum (2006) \\
\hline Melianthus major & $\begin{array}{l}\text { Petroleum ether, ethyl acetate and } \\
\text { methanol leaves extracts } \\
\text { DPPH assay: } \mathrm{IC}_{50} ; 28.08,52.21 \text { and } 4.48 \\
\mu \mathrm{g} / \mathrm{mL} \text {, respectively }\end{array}$ & * & * & ** & Srividya et al. (2010) \\
\hline Mentha longifolia & $\begin{array}{l}\text { Ethanol-water extract of aerial part } \\
\text { DPPH assay: } \mathrm{IC}_{50} ; 12.6 \mu \mathrm{g} / \mathrm{mL}\end{array}$ & * & * & ** & Ebrahimzadeh et al. (2010) \\
\hline Olea europaea & $\begin{array}{l}\text { Olive leaf methanol extract } \\
\text { TEAC assay: } 1.58 \mathrm{mM}\end{array}$ & * & * & ** & $\begin{array}{l}\text { Benavente-Garcia et al. } \\
(2000)\end{array}$ \\
\hline $\begin{array}{l}\text { Pelargonium } \\
\text { cucullatum }\end{array}$ & $\begin{array}{l}\text { The methanol leaf extract } \\
\text { DPPH assay: } \mathrm{IC}_{50} ; 40.18 \mu \mathrm{g} / \mathrm{mL}\end{array}$ & * & * & $* *$ & Saraswathi et al. (2011) \\
\hline P. graveolens & $\begin{array}{l}\text { The dichloromethane extract of leaves } \\
\text { and stem } \\
\text { DPPH scavenging activity: Ranged from } \\
0.19 \text { to } 0.39 \mathrm{mg} / \mathrm{mL}\end{array}$ & * & * & ** & $\begin{array}{l}\text { Cavar and Maksimovic } \\
\text { (2012) }\end{array}$ \\
\hline
\end{tabular}




\begin{tabular}{|c|c|c|c|c|c|}
\hline P. luridum & NA & * & * & $* *$ & Saraswathi et al. (2011) \\
\hline P. sidoides & NA & * & * & $* *$ & Saraswathi et al. (2011) \\
\hline $\begin{array}{l}\text { Pentanisia } \\
\text { prunelloides }\end{array}$ & * & $\begin{array}{l}\text { The ethanol leaf extract } \\
\text { Cyclooxygenase assay: } 88 \% \text { COX-1 inhibition at } \\
0.1 \mathrm{mg} / \mathrm{mL}\end{array}$ & * & $\begin{array}{l}\text { The ethanol leaf extract } \\
\text { MTT assay: No toxicity observed on monkey } \\
\text { kidney cells up to } 31.25 \mu \mathrm{g} / \mathrm{mL}\end{array}$ & Yff et al. (2002) \\
\hline Protea repens & * & NA & * & $* *$ & Fawole et al. (2009) \\
\hline Protea simplex & * & $\begin{array}{l}\text { Petroleum ether leaf extract } \\
\text { Cyclooxygenase assay: } 100 \% \text { COX-1 inhibition } \\
\text { at } 250 \mu \mathrm{g} / \mathrm{mL} \\
72 \% \mathrm{COX}-2 \text { inhibition at } 250 \mu \mathrm{g} / \mathrm{mL}\end{array}$ & * & $* *$ & Fawole et al. (2009) \\
\hline Rauvolfia caffra & $\begin{array}{l}\text { Aqueous ethanol extracts of root DPPH } \\
\text { assay: } 80 \% \text { inhibition at } 0.05 \mathrm{mg} / \mathrm{mL}\end{array}$ & * & * & $\begin{array}{l}\text { Ethanol extract of root } \\
\text { Brine shrimp lethality test: } \mathrm{LC}_{50} ; 47.9 \mu \mathrm{g} / \mathrm{mL}\end{array}$ & Erasto et al. (2011) \\
\hline Salvia stenophylla & $\begin{array}{l}\text { The methanol extract of aerial part } \\
\text { DPPH assay: } \mathrm{IC}_{50} ; 15.30 \mathrm{\mu g} / \mathrm{mL}\end{array}$ & $\begin{array}{l}\text { The methanol extract of aerial part } \\
\text { The } 5 \text {-lipoxygenase assay: } \mathrm{IC}_{50} ;>100 \mathrm{ppm}\end{array}$ & * & $\begin{array}{l}\text { The methanol extract of aerial part } \\
\text { MTT toxicity assay: } \mathrm{IC}_{50} ; 21.67 \mu \mathrm{g} / \mathrm{mL} \text { on } \\
\text { Graham cells }\end{array}$ & Kamatou et al. (2005) \\
\hline $\begin{array}{l}\text { Sansevieria } \\
\text { hyacinthoides }\end{array}$ & $\begin{array}{l}\text { The methanol leaf extract } \\
\text { DPPH assay: } 85.68 \% \text { inhibition at } 1000 \\
\mu \mathrm{g} / \mathrm{mL}\end{array}$ & * & * & $\begin{array}{l}\text { The methanol leaf extract } \\
\text { MTT toxicity assay: } 92.2 \% \text { cell viability at } 125 \\
\mu \mathrm{g} / \mathrm{mL} \text { on HepG2 liver cell line }\end{array}$ & $\begin{array}{l}\text { Aliero et al. (2008); } \\
\text { Philip et al. (2011 \& 2012) }\end{array}$ \\
\hline Scadoxus puniceus & $\begin{array}{l}\text { Ethyl acetate extract of root } \\
\text { ABTS assay: below } 50 \% \text { inhibition at } \\
0.125 \mathrm{mg} / \mathrm{mL} \\
\text { DPPH assay: below } 50 \% \text { inhibition at } \\
0.125 \mathrm{mg} / \mathrm{mL}\end{array}$ & $\begin{array}{l}\text { The water extract of bulbs } \\
\text { Cyclooxygenase assay: } \sim 70 \% \text { COX-1 inhibition } \\
\text { at } 2 \mathrm{mg} / \mathrm{mL}\end{array}$ & * & ** & $\begin{array}{l}\text { Adewusi and Steenkamp } \\
\text { (2011) }\end{array}$ \\
\hline Scilla natalensis & $\begin{array}{l}\text { Methanol and water extract of bulbs } \\
\text { DPPH assay: } \mathrm{IC}_{50} ;>100 \mathrm{ppm}\end{array}$ & $\begin{array}{l}\text { Aqueous leaf extract } \\
\text { 5-lipoxygenase assay: } \mathrm{IC}_{50} ;>100 \mathrm{ppm}\end{array}$ & * & ** & Frum (2006) \\
\hline
\end{tabular}




\begin{tabular}{|c|c|c|c|c|c|}
\hline Sclerocarya birrea & $\begin{array}{l}\text { Methanol extract of bark and leaves } \\
\text { DPPH assay: } \mathrm{IC}_{50} ; 5.60 \mu \mathrm{g} / \mathrm{mL}\end{array}$ & $\begin{array}{l}\text { Methanol bark extract } \\
\text { Rat paw oedema test: significant reduction at 50- } \\
500 \mathrm{mg} / \mathrm{kg}\end{array}$ & NA & $\begin{array}{l}\text { Methanol stem bark extract } \\
\text { Brine shrimp lethality assay: } \mathrm{LD}_{50} ;<5000 \\
\mathrm{mg} / \mathrm{kg} \text { body weight }\end{array}$ & $\begin{array}{l}\text { Ojewole et al. (2010); Moyo } \\
\text { et al. (2010) }\end{array}$ \\
\hline Sesamum indicum & $\begin{array}{l}\text { The ethanol extract of seed } \\
\text { DPPH assay: } \mathrm{IC}_{50} ; 87 \mu \mathrm{g} / \mathrm{mL}\end{array}$ & * & $*$ & $* *$ & $\begin{array}{l}\text { Hu et al. (2004); Hsu et al. } \\
\text { (2012) }\end{array}$ \\
\hline Sideroxylon inerme & $\begin{array}{l}\text { The methanol extract of stem bark } \\
\text { DPPH assay: } \mathrm{EC}_{50} ; 1.54 \mu \mathrm{g} / \mathrm{mL}\end{array}$ & $*$ & $\begin{array}{l}\text { Methanol extract of stem bark Anti- } \\
\text { tyrosinase assay: inhibition of } \\
\text { monophenolase at } 25 \mu \mathrm{g} / \mathrm{mL} \\
\text { Melanogenesis assay: } 37 \% \\
\text { reduction of melanin content at } 6.2 \\
\mu \mathrm{g} / \mathrm{mL}\end{array}$ & $\begin{array}{l}\text { Methanol extract of bark } \\
\text { XTT assay: } \mathrm{IC}_{50} ; 100 \mu \mathrm{g} / \mathrm{mL} \text { in } \mathrm{B}_{16} \mathrm{~F}_{10} \text { mouse } \\
\text { melanocyte cells }\end{array}$ & Momtaz et al. (2008) \\
\hline Solanum incanum & NA & * & * & $\begin{array}{l}\text { The methanol fruit extract } \\
\text { Neutral red uptake assay: } \mathrm{IC}_{50} ; 35 \mu \mathrm{g} / \mathrm{mL} \text { using } \\
\text { FL-cells }\end{array}$ & Al-Fatimi et al. (2007) \\
\hline $\begin{array}{l}\text { Sutherlandia } \\
\text { frutescens }\end{array}$ & $\begin{array}{l}\text { Ethyl acetate extract of aerial part DPPH } \\
\text { assay: } 82 \% \text { inhibition at } 0.5 \mathrm{mg} / \mathrm{mL}\end{array}$ & $\begin{array}{l}\text { Aqueous extract of aerial plant part } \\
\text { Rat paw oedema test: significant reduction at } 800 \\
\mathrm{mg} / \mathrm{kg}\end{array}$ & $*$ & $* *$ & $\begin{array}{l}\text { Katerere and Eloff (2005); } \\
\text { Ojewole (2004) }\end{array}$ \\
\hline Tecomaria capensis & $*$ & $\begin{array}{l}\text { Methanol leaves extract } \\
\text { Paw oedema assay: significant reduction of paw } \\
\text { oedema ranged from } 100-500 \mathrm{mg} / \mathrm{kg}\end{array}$ & $*$ & $\begin{array}{l}\text { The ethanol leaf extract } \\
\text { Acute toxicity assay: Single dose safe up to } \\
2000 \mathrm{mg} / \mathrm{kg} \text { in female albino rats }\end{array}$ & $\begin{array}{l}\text { Saini and Singhal (2012); } \\
\text { Jothi et al. (2012) }\end{array}$ \\
\hline Terminalia sericea & $\begin{array}{l}\text { Acetone extract of stem bark } \\
\text { DPPH assay: } 93.96 \% \text { inhibition at } 0.2 \\
\mathrm{mg} / \mathrm{mL}\end{array}$ & $*$ & $*$ & $* *$ & $\begin{array}{l}\text { Nkobole et al. (2011); } \\
\text { Mochizuki and Hasegawa } \\
\text { (2007) }\end{array}$ \\
\hline Trichilia dregeana & Leaves and twigs methanol extract & An ethyl acetate leaf extract & & & Amoo et al. (2012) \\
\hline
\end{tabular}




\begin{tabular}{|c|c|c|c|c|c|}
\hline & $\begin{array}{l}\text { DPPH assay: } 95.8 \% \text { inhibition at } 100 \\
\mu \mathrm{g} / \mathrm{mL}\end{array}$ & $\begin{array}{l}\text { Cyclooxygenase assay: } 81 \% \text { COX-2 inhibition at } \\
100 \mu \mathrm{g} / \mathrm{mL}\end{array}$ & * & $* *$ & Eldeen et al., 2005 \\
\hline Trichilia emetica & $\begin{array}{l}\text { The methanol leaf extract } \\
\text { DPPH assay: } \mathrm{IC}_{50} ; 17.9 \mu \mathrm{g} / \mathrm{mL}\end{array}$ & $\begin{array}{l}\text { Ethanol and aqueous leaf extracts } \\
\text { Cyclooxygenase assay: Inhibited prostaglandin } \\
\text { synthesis } 22 \% \text { and } 89 \% \text { at a conc. of } 5 \mathrm{mg} / \mathrm{ml} \text {, } \\
\text { respectively }\end{array}$ & $*$ & $\begin{array}{l}\text { Aqueous root extract } \\
\text { MTT reduction assay: } \mathrm{IC}_{50} ;>1000 \mathrm{mg} / \mathrm{mL}\end{array}$ & $\begin{array}{l}\text { Komane et al. (2011); } \\
\text { Germano et al. (2006) }\end{array}$ \\
\hline Warburgia salutaris & $\begin{array}{l}\text { The ethanol extract of bark } \\
\text { DPPH assay: } \mathrm{IC}_{50} ; 6.59 \mu \mathrm{g} / \mathrm{mL}\end{array}$ & $\begin{array}{l}\text { Ethanol bark extract } \\
\text { 5-lipoxygenase assay: } \mathrm{IC}_{50} ; 32.11 \mathrm{ppm}\end{array}$ & $*$ & $* *$ & Kuglerova et al. (2011) \\
\hline Withania somnifera & $*$ & $\begin{array}{l}\text { Root powder }(0.7 \& 1.4 \mathrm{~g} / \mathrm{kg} \text { body weight/ day). } \\
30 \text { days treatment; decrease in lipid peroxidation }\end{array}$ & * & ** & $\begin{array}{l}\text { Singh et al. (2010); Tong et } \\
\text { al. (2011) }\end{array}$ \\
\hline Ximenia americana & $\begin{array}{l}\text { The methanol extract of stem bark } \\
\text { DPPH assay: } \mathrm{RC}_{50} ; 82.5 \mu \mathrm{g} / \mathrm{mL}\end{array}$ & $\begin{array}{l}\text { Ethanol-water extract of root bark } \\
\text { Rat oedema test: } 12 \% \text { inhibition at } 10 \mathrm{mg} / \mathrm{kg}\end{array}$ & NA & $\begin{array}{l}\text { Aqueous ethanol root bark extract } \\
\text { Acute toxicity assay: } \mathrm{LD}_{50} ; 345 \mathrm{mg} / \mathrm{kg} \text { of body } \\
\text { weight in mice }\end{array}$ & $\begin{array}{l}\text { Maikai et al. (2010); } \\
\text { Olabissi et al. (2011) }\end{array}$ \\
\hline $\begin{array}{l}\text { Xysmalobium } \\
\text { undulatum }\end{array}$ & $\begin{array}{l}\text { The methanol extract of aerial part } \\
\text { ABTS assay: } 50 \% \text { inhibition at } 0.125 \\
\mathrm{mg} / \mathrm{mL}\end{array}$ & * & $*$ & ** & Steenkamp et al. (2004) \\
\hline Ziziphus mucronata & $\begin{array}{l}\text { The methanol leaf extract } \\
\text { ABTS assay: } \mathrm{IC}_{50} ; 8.12 \mu \mathrm{g} / \mathrm{mL}\end{array}$ & $*$ & $*$ & $* *$ & $\begin{array}{l}\text { Kwape and Chaturvedi } \\
\text { (2012) }\end{array}$ \\
\hline
\end{tabular}

FRAP = Ferric reducing antioxidant power; FRAT = Ferric-reducing antioxidant power test; DPPH = 2,2-diphenylpicrylhydrazyl; ABTS = 3-ethylbenzothiazoline-6-sulfonate assays;

BHT = Butyl hydroxyl toluene; TE/g = Trolox equivalent per gram; TEAC $=$ Trolox equivalent antioxidant capacity; ROS $=$ Reactive oxygen species; SOD $=$ Super oxide dismutase;

TBARS $=$ Thio-barbituric acid reactive substance; iNOS $=$ Inducible nitric oxide synthase expression; AEAC $=$ Ascorbic acid Equivalent Antioxidant Content; MTT $=3-[4,5-$

dimethyl-2-thiazol-yl]-2,5-diphenyl-2H-tetrazolium bromide; $\mathrm{LD}_{50}=$ Lethal Dose; MIC = Minimum Inhibitory Concentration; NA = Not active; *yet to be done **Not found 


\section{Conclusion}

The present study identified several plant species and their usage for skin care. Despite of the widespread use of plants from South Africa for skin-care, there are a very limited number of scientific studies and no clinical trials published. It is time to increase the number of scientific studies and to begin to conduct clinical studies with preparations from these taxa. Furthermore, the mechanism of action by which plant extracts and their active compounds need to be studied. In addition, the new uses of 35 species were presented. Further exploration of these preparations may lead to the discovery of novel skin care products. The ethnobotanical study showed that the use of traditional plants for skin care is still prevalent in the community especially, in the villages. The preservation of local culture, the practice of traditional medicinal plant species themselves represent important strategies for sustenance of popular knowledge of plants in the local systems of skin care.

\section{Acknowledgement}

The authors sincerely acknowledge the University of Pretoria, and National Research Foundation, South Africa for financial support.

\section{References}

Abbasi, A.M., Khan, M.A., Ahmad, M., Zafar, M., Jahan, S., Sultana, S., 2010. Ethnopharmacological application of medicinal plants to cure skin diseases and in folk cosmetics among the tribal communities of North-West Frontier Province, Pakistan. Journal of Ethnopharmacology 128, 322-335.

Abdelwahab, S.I., Hassan, L.E.A., Sirat, H.M., Yagi, S.M.A., Koko, W.S., Mohan, S., Taha, M.M.E., Ahmad, S., Chuen, C.S., Narrima, P., Rais, M.M., Hadi, A.H.A., 2011. Antiinflammatory activities of cucurbitacin E isolated from Citrullus lanatus: Role of reactive nitrogen species and cyclooxygenase enzyme inhibition. Fitoterapia 82, 11901197. 
Abegaz, B.M., Bezabih, M., Msuta, T., Brun, R., Menche, D., Muhlbacher, J., Bringmann, G., 2002. Gaboroquinones $\mathrm{A}$ and $\mathrm{B}$ and $4 \beta$ - $O$-Demethylknipholone-4 $\beta-O-\alpha$-Dglucopyranoside, Phenylanthraquinones from the roots of Bulbine frutescens. Journal of Natural Products 65, 1117-1121.

Abreu, P.M., Rosa, V.S., Araujo, E.M., Canda, A.B., Kayser, O., Bindseil, K.-U., Siems, K., Seemann, A., 1998. Phytochemical analysis and antimicrobial evaluation of Detarium microcarpum bark extracts. Pharmaceutical and Pharmacological Letters 8, 107-109.

Aburjai, T., Natsheh, F.M., 2003. Plants used in cosmetics. Phytotherapy Research 17, 9871000.

Adedapo, A.A., Jimoh, F.O., Afolayan, A.J., Masika, P.J., 2008a. Antioxidant activities and phenolic contents of the methanol extracts of the stems of Acokanthera oppositifolia and Adenia gummifera. BMC Complementary and Alternative Medicine 8, 54.

Adedapo, A.A., Jimoh, F.O., Koduru, S., Masika, P.J., Afolayan, A.J., 2008b. Evaluation of the medicinal potential of the methanol extracts of the leaves and stems of Halleria lucida. Bioresource Technology 99, 4158-4163.

Adedapo, A.A., Ofuegbe, S.O., 2013. Anti-Inflammatory and analgesic activities of soft drink leaf extract of Phyllanthus amarus in some laboratory animals. British Biotechnology Journal 3, 183-196.

Adewusi, E.A., Steenkamp, V., 2011. In vitro screening for acetylcholinesterase inhibition and antioxidant activity of medicinal plants from southern Africa. Asian Pacific Journal of Tropical Medicine 829-835.

Adhikari, A., Devkota, H.P., Takano, A., Masuda, K., Nakane, T., Basnet, P., Skalko-Basnet, N., 2008. Screening of Nepalese crude drugs traditionally used to treat hyperpigmentation: in vitro tyrosinase inhibition. International Journal of Cosmetic Science 30, 353-360.

Ahmed, A.S., Elgorashi, E.E., Moodley, N., McGaw, L.J., Naidoo, V., Eloff, J.N., 2012. The antimicrobial, antioxidative, anti-inflammatory activity and cytotoxicity of different 
fractions of four South African Bauhinia species used traditionally to treat diarrhoea. Journal of Ethnopharmacology 143, 826-839.

Al-Fatimi, M., Wurster, M., Schroder, G., Lindequist, U., 2007. Antioxidant, antimicrobial and cytotoxic activities of selected medicinal plants from Yemen. Journal of Ethnopharmacology 111, 657-666.

Ali, G.M., Yasumoto, S., Seki-Katsuta, M., 2007. Assessment of genetic diversity in sesame (Sesamum indicum L.) detected by amplified fragment length polymorphism markers. Electronic Journal of Biotechnology 10, 12-23.

Aliero, A.A., Jimoh, F.O., Afolayan, A.J., 2008. Antioxidant and antibacterial properties of Sansevieria hyacinthoides. International Journal of Pure and Applied Sciences 3, 103110.

Alvarez, A.M.R., Rodriguez, M.L.G., 2000. Lipids in pharmaceutical and cosmetic preparations. Grasasy Aceites 51, 74-96.

Amoo, S.O., Aremu, A.O., Moyo, M., Van Staden, J., 2012. Antioxidant and acetylcholinesterase-inhibitory properties of long-term stored medicinal plants. BMC Complementary and Alternative Medicine 12, 87.

Anilkumar, K.R., Pal, A., Khanum, F., Bawa, A.S., 2010. Nutritional, medicinal and industrial uses of sesame (Sesamum indicum L.), seeds-an overview. Agriculturae Conspectus Scientificus 75, 159-168.

Anitha, T., 2012. Medicinal plants used in skin protection. Asian Journal of Pharmaceutical and Clinical Research, 5, 35-38.

Aremu, A.O., Fawole, O.A., Chukwujekwu, J.C., Light, M.E., Finnie, J.F. Van Staden J., 2010. In vitro antimicrobial, anthelmintic and cyclooxygenase-inhibitory activities and phytochemical analysis of Leucosidea sericea. Journal of Ethnopharmacology 131, 2227.

Arnold, H.J., Gulumian, M., 1984. Pharmacopoeia of traditional medicine in Venda. Journal of Ethnopharmacology 12, 35-74. 
Assimopoulou, A.N., Sinakos, Z., Papageorgiou, V.P., 2005. Radical scavenging activity of Crocus sativus L. extract and its bioactive constituents. Phytotherapy Research 19, 9971000.

Babajide, O.J., Mabusela, W.T., Green, I.R., Ameer, F., Weitz, F., Iwuoha, E.I., 2010. Phytochemical screening and biological activity studies of five South African indigenous medicinal plants. Journal of Medicinal Plants Research 2, 1924-1932.

Bandyopadhyay, K., Ghosh, S., 2002. Preparation and characterization of papain-modified sesame (Sesamum indicum L.) protein isolates. Journal of Agriculture and Food Chemistry 50, 6854-6857.

Beer, D., Joubert, E., Malherbe, C.J., Brand, D.J., 2011. Use of countercurrent chromatography during isolation of 6-hydroxyluteolin-7-O- $\beta$-glucoside, a major antioxidant of Athrixia phylicoides. Journal of Chromatography A 1218, 6179-6186.

Benavente-Garcia, O., Castillo, J., Lorente, J., Ortuno, A., Rio, J.A.D., 2000. Antioxidant activity of phenolics extracted from Olea europaea L. leaves. Food Chemistry 68, 457462.

Bianco, A., Scalzo, R., Scarpati, M.L., 1993. Isolation of cornoside from Olea europaea and its transformation in to halleridone. Phytochemistry $32,455-457$.

Botes, L., Westhuizen, F.H., Loots, D.T., 2008. Phytochemical contents and antioxidant capacities of two Aloe greatheadii var. davyana extracts. Molecules 13, 2169-2180.

Breiter, T., Laue, C., Kressel, G., Groll, S., Engelhardt, U.H., Hahn, A., 2011. Bioavailability and antioxidant potential of rooibos favonoids in humans following the consumption of different rooibos formulations. Food Chemistry 128, 338-347.

Brien, S., Lewith, G.T., Mc Gregor, G., 2006. Devil's claw (Harpagophytum procumbens) as a treatment for osteoarthritis: A review of efficacy and safety. The Journal of Alternative and Complementary Medicine 12, 981-993. 
Burits, M., Asres, K., Bucar, F., 2001. The antioxidant activity of the essential oils of Artemisia afra, Artemisia abyssinica and Juniperus procera. Phytotherapy Research 15, 103-108.

Caluwe, E.D., Halamova, K., Damme, P.V., 2010. Adansonia digitata L -A review of traditional uses, phytochemistry and pharmacology. Afrika focus 23, 11-51.

Cavar, S., Maksimovic, M., 2012. Antioxidant activity of essential oils? and aqueous extract? of Pelargonium graveolens L'Her. Food Control 23, 263-267.

Chaudhari, P.M., Kawade, P.V., Funne, S.M., 2011.Cosmeceuticals-A review. International Journal of Pharmacy \& Technology 3, 774-798.

Chen, W., Wyk, B.-E., Vermaak, I., Viljoen, A.M., 2012. Cape aloes- A review of the phytochemistry, pharmacology and commercialisation of Aloe ferox. Phytochemistry Letters 5, 1-12.

Cheng, C.L., Koo, M.W.L., 2000. Effects of Cassia auriculata on ethanol induced gastric mucosal lesions in rats. Life Science 67, 2647-2653.

Chinsembu, K.C., Hedimbi, M., Mukaru, W.C., 2011. Putative medicinal properties of plants from the Kavango region, Namibia. Journal of Medicinal Plants Research 5, 6787-6797.

Chivandi, E., Davidson, B.C., Erlwanger, K.H., 2008. A comparison of the lipid and fatty acid profiles from the kernels of the fruit (nuts) of Ximenia caffra and Ricinodendron rautanenii from Zimbabwe. Industrial Crops and Products 27, 29-32.

Clarkson, C., Maharaj, V.J., Crouch, N.R., Grace, O.M., Pillay, P., Matsabisa, M.G., Bhagwandin, N., Smith, P.J., Folb, P.I., 2004. In vitro antiplasmodial activity of medicinal plants native to or naturalised in South Africa. Journal of Ethnopharmacology 92, 177-191.

Codd, L.E., 1985. The genus Ballota. Flora of Southern Africa 28, 48-50.

Corrigan, B.M., Van Wyk, B-E., Geldenhuys, C.J., Jardine, J.M., 2011. Ethnobotanical plant uses in the KwaNibela Peninsula, St Lucia, South Africa. South African Journal of Botany 77, 346-359. 
De Wet, H., Nciki, S., van Vuuren, S.F., 2013. Medicinal plants used for the treatment of various skin disorders by a rural community in northern Maputaland, South Africa Journal of Ethnobiology and Ethnomedicine 9:51.

Diallo, D., Paulsen, B.S., Liljeback, T.H.A., Michaelsen, T.E., 2003. The malian medicinal plant Trichilia emetica; studies on polysaccharides with complement fixing ability. Journal of Ethnopharmacology 84, 279-287.

Dubey, N.K., Kumar, R., Tripathi, P., 2004. Global promotion of herbal medicine: India's opportunity. Current Science 86, 37-41.

Duncan, G., 1998. Grow Agapanthus, A guide to the species, cultivation and propagation of the genus Agapanthus, National Botanical Institute, Trident Press, Cape Town.

Dureja, H., Kaushik, D., Gupta, M., Kumar, V., Lather, V., 2005. Cosmeceuticals: An emerging concept. Indian Journal of Pharmacology 37, 155-159.

Dweck, A.C., 2011. A data base: Article for cosmetics and toiletries magazine ethnobotanical plants from Africa part two, Research Director, Peter Black Medicare Ltd. White Horse Business Park, Aintree Avenue, Wiltshire, UK BA14 0XB.

Dyson, A., 1998. Discovering indigenous healing plants of the herb and fragrance gardens at Kirstenbosch National Botanical Garden. NBI, Cape Town.

Ebrahimzadeh, M.A., Nabavi, S.M., Nabavi, S.F., 2010. Antioxidant and antihemolytic activities of Mentha longifolia. Pharmacologyonline 2, 464-471.

Eldeen, I.M., Elgorashi, E.E., van Staden, J., 2005. Antibacterial, anti-inflammatory, anticholinesterase and mutagenic effects of extracts obtained from some trees used in South African traditional medicine. Journal of Ethnopharmacology 102, 457-464.

Eloff, J.N., 2001. Antibacterial activity of Marula (Sclerocarya birrea (A. rich) Hochst. subsp. caffra (Sond.) Kokwaro) (Anacardiaceae) bark and leaves. Journal of Ethnopharmacology 76, 305-308. 
Erasto, P., Mbwambo, Z.H., Nondo, R.S.O., Lall, N., Lubschagne, A., 2011. Antimycobacterial, antioxidant activity and toxicity of extracts from the roots of Rauvolfia vomitoria and $R$. caffra. Spatula DD 1, 73-80.

Farhan, H., Rammal, H., Hijazi, A., Hamad, H., Daher, A., Reda, M., Badran, B., 2012. In vitro antioxidant activity of ethanolic and aquous extracts from crude Malva parviflora L. grown in Lebanon. Asian Journal of Pharmaceutical and Clinical Research 5, 234-238.

Fawole, O.A., Amoo, S.O., Ndhlala, A.R., Light, M.E., Finnie, J.F., Van Staden, J., 2010. Anti-inflammatory, anticholinesterase, antioxidant and phytochemical properties of medicinal plants used for pain-related ailments in South Africa. Journal of Ethnopharmacology, 127, 235-241.

Fawole, O.A., Ndhlala, A.R., Amoo, S.O., Finnie, J.F., Van Staden, J., 2009. Antiinflammatory and phytochemical properties of twelve medicinal plants used for treating gastro-intestinal ailments in South Africa. Journal of Ethnopharmacology 123, 237-243.

Fernandes, L., van Rensburg, C.E.J., Hoosen, A.A., Steenkamp, V., 2008. In vitro activity of medicinal plants of the Venda region, South Africa, against Trichomonas vaginalis. South African Journal of Epidemiology Infection 23, 26-28.

Fox, F.W., Norwood, Y.M.E., 1982. Food from the veld, edible wild plants of southern Africa. Delta Books, Johannesburg.

Frum, Y., 2006. In vitro 5-lipoxygenase and anti-oxidant activities of South African medicinal plants commonly used topically for skin diseases, MSc. Dissertation, University of the Witwatersrand, Johannesburg.

Frum, Y., Viljoen, A.M., Van Heerden, F.R., 2007. Verbascoside and luteolin-5-O- $\beta$-Dglucoside isolated from Halleria lucida L. exhibit antagonistic anti-oxidant properties in vitro. South African Journal of Botany 73, 583-587.

Gabriel, O.A., Olubunmi, A., 2009. Comprehensive scientific demystification of Kigelia africana: A review. African Journal of Pure and Applied Chemistry 3,158-164. 
George, M., Joseph, L., Ramaswamy., 2009. Anti-allerigic, anti-pruritic, and antiinflammatory activities of Centella asiatica extracts. African Journal of Traditional, Complementary and Alternative Medicine 6, 554-559.

Georgiev, M.I., Alipieva, K., Orhan, I.E., 2012. Cholinesterases inhibitory and antioxidant activities of Harpagophytum procumbens from in vitro systems. Phytotherapy Research 26, 313-316.

Gericke, N., Van Oudtshoorn, B., Van Wyk, B., 1997. Medicinal Plants of South Africa Briza. Pretoria.

Germano, M.P., D'Angelo, V.D., Biasini, T., Sanogo, R., De Pasquale, R., Catania, S., 2006. Evaluation of the antioxidant properties and bioavailability of free and bound phenolic acids from Trichilia emetica Vahl. Journal of Ethnopharmacology 105, 368-373.

Germishuizen, G., Meyer, N.L., 2003. Plants of southern Africa: an annotated checklist. Strelitzia 14, National Botanical Institute, Pretoria.

Gerstner, J., 1938. A preliminary checklist of Zulu names of plants with short notes. Bantu Studies, 12, 215-236.

Gerstner, J., 1941. A preliminary checklist of Zulu names of plants with short notes?. Bantu Studies 15, 277-383.

Glaser, D.A., 2004. Anti-aging products and cosmeceuticals. Facial Plastic Surgery Clinics of North America 12, 363-372.

Goldblatt, P., Manning, J., 2000. Cape plants, a conspectus of the Cape flora of South Africa Strelitzia 9. National Botanical Institute, Pretoria \& Missouri Botanical Garden, Missouri.

Goudoum, A., Tinkeu, L.S.N., Ngassoum, M.B., Mbofung, C.M., 2009. Antioxidant activities of essential oils of Clausena anisata (Rutaceae) and Plectranthus glandulosus (Labiateae), plants used against stored grain insects in North Cameroon. International Journal of Biological and Chemical Sciences 3, 567-577. 
Grassi, L.T., Malheiros, A., Meyre-Silva, C., Buss, Z.S., Monguilhott, E.D., Frode, T.S., daSilva, K.A.B.S., Souza, M.M., 2013. From popular use to pharmacological validation: A study of the anti-inflammatory, anti-nociceptive and healing effects of Chenopodium ambrosioides extract. Journal of Ethnopharmacology 145, 127-138.

Grierson, D.S., Afolayan, A.J., 1999. An ethnobotanical study of plants used for the treatment of wounds in the Eastern Cape, South Africa. Journal of Ethnopharmacology 67, 327332.

Gruenwald, J., 2006. Anti-aging nutraceuticals. Food Science and Technology 20, 50-51.

Gupta, C., Goyal, S., Gupta, S., 2011. Cosmeceuticals: Beauty behind plants. Journal of Pharmacy Research 4, 56-57.

Halder, R.M., Richards, M.D., Richards, G.M., 2004. Topical agents used in the management of hyperpigmentation. Skin Therapy Letter 9, 1-3.

Hassan, H.S., Ahmadu, A.A., Hassan, A.S., 2008. Analgesic and anti-inflammatory activities of Asparagus africanus root extract. African Journal of Traditional, Complementary and Alternative Medicine 5, 27-31.

Hassan, H.S., Sule, M.I., Musa, A.M., Musa, K.Y., Abubakar, M.S., Hassan, A.S., 2012. Antiiinflammatory activity of crude saponin extracts from five Nigerian medicinal plants. African Journal of Traditional, Complementary and Alternative Medicine 9, 250255.

Hassan, L.E.A., Sirat, H.M., Yagi, S.M.A., Koko, W.S., Abdelwahab, S.I., 2011. In vitro Antimicrobial activities of chloroformic, hexane and ethanolic extracts of Citrullus lanatus var. citroides (Wild melon). Journal of Medicinal Plants Research 5, 1338-1344.

Hein, A.J., Wicker, C.M., Palmer, C.F., 2009. Natural butters reconstituted by transesterification with glycerine and its use in cosmetic applications. Patent US 2009/0285876 A1.

Houghton, C., 1999. New natural oils and their properties. Anglia Oils Ltd., Bulk Speciality Division, Norfolk. 
Hsouna, A.B., Hamdi, N., 2013. Phytochemical composition and antimicrobial activities of the essential oils and organic extracts from pelargonium graveolens growing in Tunisia. Hsouna and Hamdi Lipids in Health and Disease 11, 167-173.

Hsu, D.-Z., Chu, P.-Y., Li, M.-Y., 2012. Sesame seed (Sesamum indicum L.) extracts and their anti-inflammatory effect. ACS Symposium Series DOI: 10.1021/bk-20121093.ch019.

Hu, Q., Xu, J., Chen, S., Yang, F., 2004. Antioxidant activity of extracts of black sesame seed (Sesamum indicum L.) by supercritical carbon dioxide extraction. Journal of Agriculture and Food Chemistry 52, 943-947.

Hutchings, A., 1996. Zulu Medicinal Plants. University of Natal Press. Pietermaritzburg.

Hutchings, A., Scott, A.H., Lewis, G., Cunningham, A.B., 1996. Zulu Medicinal Plants. University of Natal Press, Pietermaritzburg.

Ibtissem, B., Abdelly, C., Sfar, S., 2012. Antioxidant and antibacterial properties of Mesembryanthemum crystallinum and Carpobrotus edulis extracts. Advances in Chemical Engineering and Science 2, 359-365.

Iwu, M.M., 1986. African Ethnomedicine. Second ed. SNAAP Press, Enugu, Nigeria 173.

Jackson, S.J., Houghton, P.J., Retsas, S., Photiou, A., 2000. In vitro cytotoxicity of Norviburtinal and Isopinnatal from Kigelia pinnata against cancer cell lines. Planta Medica 66, 758-761.

Jackson, W.P.U., 1990. Origins and meanings of names of South African plant genera. U.C.T. Printing Dept., Cape Town.

Jacobsen, W.B.G., 1983. The ferns and fern allies of Southern Africa. Butterworths, South Africa, pp. 284, 446, 448, 449.

Jain, A., Dubey, S., Gupta, A., Kannojia, P., Tomar, V., 2010. Potential of herbs as cosmeceuticals. International Journal of Research in Ayurveda \& Pharmacy 1, 71-77.

Jarret, R.L., Levy, I.J., 2012. Oil and fatty acid contents in seed of Citrullus lanatus schrad. Journal of Agriculture and Food Chemistry 60, 5199-5204. 
Joffe, P., 1993. The gardener's guide to South African plants. Table Mountain Publishers, Cape Town.

Joffe, P., 2003. Creative gardening with indigenous plants. Briza Publications, Pretoria.

Jothi, E.T., Nithya, P.D., Lakshmi, N.V., Chand, V.G., Babu, P.S., 2012. In vitro anti inflammatory activity of Tecomaria Capensis (Thunb) leaves of different extracts. Current Pharma Research 2, 524-526.

Joubert, E., Gelderblom, W.C.A., Louw, A., de Beer, D., 2008. South African herbal teas: Aspalathus linearis, Cyclopia spp. and Athrixia phylicoides-A review. Journal of Ethnopharmacology 119, 376-412.

Juliani, H.R., Koroch, A.R., Simon, J.E., Wamulwange, C., 2007. Mungongo cold pressed oil (Schinziophyton rautanenii): A new natural product with potential cosmetic applications. Acta Horticulturae 756, 407-412.

Juma, B.F., Majinda, R.R.T., 2005. Three new compounds from Erythrina lysistemon and their antimicrobial, radical scavenging activities and their brine shrimp lethality. 11th NAPRECA Symposium Book of Proceedings, Antananarivo, Madagascar Pages 97-109, August 9-12.

Kamatou, G.P.P., Vermaak, I., Viljoen, A.M., 2011. An updated review of Adansonia digitata: A commercially important African tree. South African Journal of Botany 77, 908-919.

Kamatou, G.P.P., Viljoen, A.M., Gono-Bwalya, A.B., van Zyl, R.L., van Vuuren, S.F., Lourens, A.C.U., Baser, K.H.C., Demirci, B., Lindsey, K.L., van Staden, J., Steenkamp, P., 2005. The in vitro pharmacological activities and a chemical investigation of three South African Salvia species. Journal of Ethnopharmacology 102, 382-390.

Kambizi, L., Goosen, B.M., Taylor, M.B., Afolayan, A.J., 2007. Anti-viral effects of aqueous extracts of Aloe ferox and Withania somnifera on herpes simplex virus type 1 in cell culture. South African Journal of Science 103, 359-360. 
Kapoor, L.D., 2001. Hand Book of Ayurvedic Medicinal Plants, Herbal Reference Library Edition. CRC Press, New York.

Katerere, D.R., Eloff, J.N., 2005. Antibacterial and antioxidant activity of Sutherlandia frutescens (Fabaceae), a reputed anti-HIV/AIDS phytomedicine. Phytotherapy Research $19,779-781$.

Katiyar, C., Gupta, A., Kanjilal S, Katiyar S, 2012. Drug discovery from plant sources: An integrated approach. Ayurveda 33, 10-19.

Katiyar, S.K., 2005. Silymarin and skin cancer prevention: Anti-inflammatory, antioxidant and immunomodulatory effects (Reiev). International Journal of Oncology 26, 139-176.

Kaur, G., Jabbar, Z., Athar, M., Alam, M.S., 2006. Punica granatum (pomegranate) flower extract possesses potent antioxidant activity and abrogates Fe-NTA induced hepatotoxicity in mice. Food and Chemical Toxicolgy 44, 984-993.

Kazuno, S., Yanagida, M., Shindo, N., Murayama, K., 2005. Mass spectrometric identification and quantification of glycosyl flavonoids, including dihydrochalcones with neutral loss scan mode. Analytical Biochemistry 347, 182-192.

Kelmanson, J.E., Jager, A.K., van Staden, J., 2000. Zulu medicinal plants with antibacterial activity. Journal of Ethnopharmacology 69, 241-246.

Kiken, D.A., Cohen, D.E., 2002. Contact dermatitis to botanical extracts. American Journal of Contact Dermatitis 13, 148-152.

Kim, H.P., Son, K.H., Chang, H.W., Kang, S.S., 2004. Anti-inflammatory plant flavonoids and cellular action mechanisms. Journal of Pharmacological Sciences 96, 229-245.

Kirtikar, K.R., Basu, B.D., 1975. Indian Medicinal Plants, Vol. II, Periodical Experts, New Delhi, 2nd Ed.

Komane, B.M., Olivier, E.I., Viljoen, A.M., 2011. Trichilia emetica (Meliaceae)- A review of traditional uses, biological activities and phytochemistry. Phytochemistry Letters 4, 1-9. 
Kuglerova, M., Tesarova, H., Grade, J.T., Halamova, K., Wanyana-Maganyi, O., Damme, P.V., Kokoska, L., 2011. Antimicrobial and antioxidative effects of Ugandan medicinal barks. African Journal of Biotechnology 10, 3628-3632.

Kumar, B., Govindarajan, M., Pusphagandan ,R., 2007. Ethanopharmacological approaches to wound healing-Exploring medicinal plants of India. Journal of Ethanopharmacology $114,103-113$.

Kumar, P.S., Sucheta, S., Deepa, V.S., Selvamani, P., Latha, S., 2008. Antioxidant activity in some selected Indian medicinal plants. African Journal of Biotechnology 7, 1826-1828.

Kumaraswamy, H.M., Krishna, V., Shankar murthy, K., Rahiman, A.B., Mankani, K.L., Mahadevan, K.M., Harish, B.G., Naika, R.H., 2007. Wound healing activity of embelin isolated from the ethanol extract of leaves of Embelia ribes Burm. Journal of Ethnopharmacology 109, 529-534.

Kwape, T.E., Chaturvedi, P., Antiooxidant activities of leaf extracts of Ziziphus mucronata. International Journal of Food, Agriculture and Veterinary Sciences 2, 62-69.

Laghetti, G., Hammer, K., 2007. The Corsican citron melon [Citrullus lanatus (Thunb.) Matsumura \& Nakai subsp. lanatus var. citroides (Bailey) Mansf. ex Greb.] a traditional and neglected crop. Genetic Resources and Crop Evolution 54, 913-916.

Lamien-Meda, A., Lamien, C.E., Compaore, M.M.Y., Meda, R.N.T., Kiendrebeogo, M., Zeba, B., Millogo, J.F., Nacoulma, O.G., 2008. Polyphenol content and antioxidant activity of fourteen wild edible fruits from Burkina Faso. Molecules 13, 581-594.

Lans, C., 2007. Comparison of plants used for skin and stomach problems in Trinidad and Tobago with Asian ethnomedicine. Journal of Ethnobiology and Ethnomedicine 3, 3.

Leistner, O.A., 2000. Seed plants of southern Africa: families and genera, Strelitzia 10, National Botanical Institute, Pretoria.

Lohdip, A.M., Tyonande, T.T., 2005. Analysis of Asparagus africanus (LAM) for some hair growth-stimulating elements. ChemClass Journal 2, 93-94. 
Loots, D.T., Westhuizen, F.H., Botes, L., 2007. Aloe ferox leaf gel phytochemical content, antioxidant capacity, and possible health benefits. Journal of Agriculture and Food Chemistry 55, 6891-6896.

Louw, C.A.M., Regnier, T.J.C., Korsten, L., 2002. Medicinal bulbous plants of South Africa and their traditional relevance in the control of infectious diseases. Journal of Ethnopharmacology 82, 147-154.

Lucky, O.O., John, U.O., Kate, I.E., Peter, O.O., Jude, O.E., 2012. Quantitative determination, Metal analysis and Antiulcer evaluation of Methanol seeds extract of Citrullus lanatus Thunb (Cucurbitaceae) in Rats. Asian Pacific Journal of Tropical Disease S804-S808.

Mabona, U., Viljoen, A., Shikanga, E., Marston, A., Van Vuuren, S., 2013. Antimicrobial activity of southern African medicinal plants with dermatological relevance: From an ethnopharmcological screening approach, to combination studies and the isolation of a bioactive compound. Journal of Ethnopharmacology 148, 45-55.

Maikai, V.A., Kobo, P.I., Maikai, B.V.O., 2010. Antioxidant properties of Ximenia americana. African Journal of Biotechnology 9, 7744-7746.

Maikai, V.A., Nok, A.J., Alawa, C.B.I., Adaudi, A.O., 2007. The effect of Ximenia americana in mice experimentally infected with Trypanosoma congolense. International Journal of Bioscience 2, 48-52.

Makunga, N.P., Philander, L.E., Smith, M., 2008. Current perspectives on an emerging formal natural products sector in South Africa. Journal of Ethnopharmacology 119, 365375.

Maphosa, V., Masika, P.J., Moyo, B., 2009. Investigation of the anti-inflammatory and antinociceptive activities of Elephantorrhiza elephantine (Burch.) Skeels root extract in male rats. African Journal of Biotechnology 8, 7068-7072.

Mapunya, M.B., Hussein, A.A., Rodriguez, B., Lall, N., 2011. Tyrosinase activity of Greyia flanaganii (Bolus) constituents. Phytomedicine 18, 1006-1012. 
Mapunya, M.B., Nikolova, R.V., Lall, N., 2012. Melanogenesis and antityrosinase activity of selected South African plants. Evidence Based Complement Alternative Medicine, Article ID 374017, P6.

Mariod, A.A., Matthaus, B., Idris, Y.M.A., Abdelwahab, S.I., 2010. Fatty acids, tocopherols, phenolics and the antimicrobial effect of Sclerocarya birrea kernels with different harvesting dates. Journal of the American Oil Chemists Society 87, 377-384.

Marnewick, J., Joubert, E., Joseph, S., Swanevelder, S., Swart, P., Gelderblom, W., 2005. Inhibition of tumour promotion in mouse skin by extracts of rooibos (Aspalathus linearis) and honeybush (Cyclopia intermedia), unique South African herbal teas. Cancer Letters 224, 193-202.

Marnewick, J.L., Rautenbach, F., Venter, I., Neethling, H., Blackhurst, D.M., Wolmarans, P., Macharia, M., 2011. Effects of rooibos (Aspalathus linearis) on oxidative stress and biochemical parameters in adults at risk for cardiovascular disease. Journal of Ethnopharmacology 133, 46-52.

Maroyi, A., 2013. Warburgia salutaris (Bertol. f.) Chiov.: A multi-use ethnomedicinal plant species. Journal of Medicinal Plants Research 7, 53-60.

Martins, A., Vasas, A., Viveiros, M., Molnar, J., Hohmann, J., Amaral, L., 2011. Antibacterial properties of compounds isolated from Carpobrotus edulis. International Journal of Antimicrobial Agents 37, 438-444.

McGaw, L.J., Steenkamp, V., Eloff, J.N., 2007. Evaluation of Athrixia bush tea for cytotoxicity, antioxidant activity, caffeine content and presence of pyrrolizidine alkaloids. Journal of Ethnopharmacology 110, 16-22.

McKay, D.L., Blumberg, J.B., 2007. A Review of the Bioactivity of South African Herbal Teas: Rooibos (Aspalathus linearis) and Honeybush (Cyclopia intermedia). Phytotherapy Research 21, 1-16.

Miguel, M.G., 2010. Antioxidant and anti-inflammatory activities of essential oils: A Short Review. Molecules 15, 9252-9287. 
Mochizuki, M., Hasegawa, N., 2007. Anti-inflammatory effect of extract of Terminalia sericea roots in an experimental model of colitis. Journal of Health Science 53, 329-331.

Mohamed, I.E., El-Nur, B.E., Choudhary, M.I., Khan, S.N., 2009. Bioactive Natural Products from Two Sudanese Medicinal Plants Diospyros mespiliformis and Croton zambesicus. Records of Natural Products 3, 198-203.

Mokoka, T. A., McGaw, L. J., Eloff, J. N., 2010. Antifungal efficacy of ten selected South African plant species against Cryptococcus neoformans. Pharmaceutical Biology 48, $397-404$.

Momtaz, S., Lall, N., Basson, A., 2008b. Inhibitory activities of mushroom tyrosine and DOPA oxidation by plant extracts. South African Journal of Botany 74, 577-582.

Momtaz, S., Mapunya, B.M., Houghton , P.J., Edgerly, C., Hussein, A., Naidoo, S., Lall, N., 2008a. Tyrosinase inhibition by extracts and constituents of Sideroxylon inerme L. stem bark, used in South Africa for skin lightening. Journal of Ethnopharmacology 119, 507512.

Momtaz. S., Lall, N., Hussein, A., Ostad, S.N., Abdollahi, M., 2010. Investigation of the possible biological activities of a poisonous South African plant; Hyaenanche globosa (Euphorbiaceae). Pharmacognosy Magazine 6, 34-41.

Moolla, A., Viljoen, A.M., 2008. 'Buchu'-Agathosma betulina and Agathosma crenulata (Rutaceae): A review. Journal of Ethnopharmacology 119, 413-419.

More, G., Lall, N., Hussein, A., Tshikalange, T.E., 2012. Antimicrobial constituents of Artemisia afra Jacq. exWilld. against periodontal pathogens. Evidence-Based Complementary and Alternative Medicine Article ID 252758, 7p.

Mourtzinos, I., Salta, F., Yannakopoulou, K., Chiou, A., Karathanos, V.T., 2007. Encapsulation of olive leaf extract in $\beta$-Cyclodextrin. Journal of Agriculture and Food Chemistry 55, 8088-8094. 
Moyo, M., Ndhlala, A.R., Finnie, J.F. Van Staden, J., 2010. Phenolic composition, antioxidant and acetylcholinesterase inhibitory activities of Sclerocarya birrea and Harpephyllum caffrum (Anacardiaceae) extracts. Food Chemistry 123, 69-76.

Mozherenkov, V.P., Shubina, L.F., 1976. Treatment of chronic conjunctivitis with Calendula. Medicinska Sestra 35, 33-34.

Mukul, S., Surabhi, K., Atul, N., 2011. Cosmeceutical for the skin: An overview. Asian Journal of Pharmaceutical and Clinical Research 4, 1-6.

Muley, B.P., Khadabadi, S.S., Banarase, N.B., 2009. Phytochemical constituents and pharmacological activities of Calendula officinalis Linn (Asteraceae): A Review. Tropical Journal of Pharmaceutical Research 8, 455-465.

Nadkarni, K.M., 1976. Indian Materia Medica, (2 vol) Popular Prakashan Publications. Ltd., Bombay.

Nakano, M., Nakashima, H., Itoh, Y., 1997. Anti-human immunodeficiency virus activity of oligosaccharides from Rooibos tea (Aspalathus linearis) extracts in vitro. Leukemia 11, 128-130.

Ndawonde, B.G., Zobolo, A.M., Dlamini, E.T., Siebert, S.J., 2007. A survey of plants sold by traders at Zululand muthi markets, with a view to selecting popular plant species for propagation in communal gardens. African Journal of Range and Forage Science 42, 103-107.

Ndukui, J.G., Muwonge, H., Sembajwe, L.F., 2012. Aphrodisiac potential and phytochemical profile of Ekebergia capensis (Cape ash) in male albino rats, Spatula DD 2, 237-243.

Neo, Y.P., Ariffin, A., Tan, C.P., Tan, Y.A., 2008. Determination of oil palm fruit phenolic compounds and their antioxidant activities using spectrophotometric methods. International Journal Food Science and Technology 43, 1832-1837.

Neuwinger, H.D., 2000. African traditional medicine, a dictionary of plant use and applications. Medpharm Scientific Publishers, Stuttgart. 
Ngwenya, M.A., Koopman, A., Williams, R., 2003. Zulu Botanical Knowledge: An Introduction. National Botanical Institute, Durban.

Njenga, E.W., Viljoen, A.M., 2006. In vitro 5-lipoxygenase inhibition and anti-oxidant activity of Eriocephalus L. (Asteraceae) species. South African Journal of Botany 72, $637-641$.

Njenga, E.W., Vuuren, S.F., Viljoen, A.M., 2005. Antimicrobial activity of Eriocephalus L species. South African Journal of Botany 71, 81-87.

Njume, C., Afolayan, A.J., Green, E., Ndip, R.N., 2011. Volatile compounds in the stem bark of Sclerocarya birrea (Anacardiaceae) possess antimicrobial activity against drugresistant strains of Helicobacter pylori. International Journal of Antimicrobial Agents 38, 319-324.

Nkobole, N., Houghton, P.J., Hussein, A. Lall, N., 2011. Antidiabetic activity of Terminalia sericea Burch. ex DC constituents. Natural Product Communications 6, 3.

Nkomo, M., Nkeh-Chungag, B.N., Kambizi, L., Ndebia, E.J., Iputo, J.E., 2010. Antinociceptive and anti-inflammatory properties of Gunnera perpensa (Gunneraceae) African Journal Pharmacy and Pharmacology 4, 263-269.

Ogunleye, D.S., Ibitoye, S.F., 2003. Studies of antimicrobial activity and chemical constituents of Ximenia americana. Tropical Journal of Pharmaceutical Research 2, 239241.

Ojewole, J.A.O., 2004. Analgesic, antiinflammatory and hypoglycemic effects of Sutherlandia frutescens R. BR. (variety Incana E. MEY.) [Fabaceae] shoot aqueous extract. Method and Findings in Experimental and Clinical Pharmacology 26, 409-416.

Ojewole, J.A.O., Mawoza, T., Chiwororo, W.D.H., Owira, P.M.O., 2010. Sclerocarya birrea (A. Rich) Hochst. ['Marula'] (Anacardiaceae): A review of its phytochemistry, pharmacology and toxicology and its ethnomedicinal uses. Phytotherapy Research 24, 633-639. 
Okokon, J.E., Udoh, A.E., Andrew, U.E., Amazu, L.U., 2012. Antiinflammatory and antipyretic activities of Clausena anisata. Molecular \& Clinical Pharmacology 3, 47-54.

Okoye, E.I., Onyekwelli, A.O., Ohwoavworhua, F.O., Kunle, O.O., 2009. Comparative study of some mechanical and release properties of paracetamol tablets formulated with cashew tree gum, povidone and gelatin as binders. African Journal of Biotechnology 8, $3970-3973$.

Oktay, M., Gulcin, I., Kufrevioglu, O.I., 2003. Determination of in vitro antioxidant activity of fennel (Foeniculum vulgare) seed extracts. Lebensmittel-Wissenschaft U-Technology $36,263-271$.

Olabissi, O.A., Moussa, O., Moustapha, O., Edgard, Z.F., Eleonore, K., Marius, L., Pierre, G.I., 2011. Acute toxicity and anti-inflammatory activity of aqueous ethanol extract of root bark of Ximenia americana L. (Olacaceae). African Journal Pharmacy and Pharmacology 5, 806-811.

Olalye, M.T., Rocha, J.B.T., 2007. Commonly used tropical medicinal plants exhibit distinct in vitro antioxidant activities against hepatotoxins in rat liver. Experimental and Toxicological Pathology 58, 433-438.

Olivier, D.K., Shikanga, E.A., Combrinck, S., Krause, R.W.M., Regnier, T., Dlamini, T.P., 2010. Phenylethanoid glycosides from Lippia javanica. South African Journal of Botany $76,58-63$.

Oloyede, G.K., Onocha, P.A., Soyinka, J., Oguntokun, O., Thonda, E., 2010. Phytochemical screening, antimicrobial and antioxidant activities of four Nigerian medicinal plants. Annals of Biological Research 1, 114-120.

Omoruyi, B.E., Bradley, G., Afolayan, A.J., 2012. Antioxidant and phytochemical properties of Carpobrotus edulis (L.) bolus leaf used for the management of common infections in HIV/AIDS patients in Eastern Cape Province. BMC Complementary and Alternative Medicine 12, 215. 
Palgrave, K.C., 2002. Trees of Southern Africa, In: Moll EJ, Ed. Cape Town: Struik Publishers.

Palmer, E., Pitman, N., 1972. Trees of Southern Africa, A.A. Balkema, Cape Town.

Pandey, S., Meshya, N., Viral, D., 2010. Herbs play an important role in the field of cosmetics. International Journal of PharmTech Research 2, 632-639.

Parameswaran, T.N., Kalra, A., Mehta, V.K., Radhakrishnan, K., 2000. Chemical control of tip burn and blight of scented geranium (Pelargonium graveolens) caused by Colletotrichum gloeosporioides under South Indian hill conditions. Journal of Medicinal and Aromatic Plant Science 22, 666-668.

Pather, N., Viljoen, A.M., Kramer, B., 2011. A biochemical comparison of the in vivo effects of Bulbine frutescens and Bulbine natalensis on cutaneous wound healing. Journal of Ethnopharmacology 133, 364-370.

Pesewu, G.A., Cutler, R.R., Humber, D.P., 2008. Antibacterial activity of plants used in traditional medicines of Ghana with particular reference to MRSA. Journal of Ethnopharmacology 116, 102-111.

Philander, L.A., 2011. An ethnobotany of Western Cape Rasta bush medicine. Journal of Ethnopharmacology 138, 578-594.

Philip, D., Kaleena, P.K., Valivittan, K., 2011. In vitro cytotoxicity and anticancer activity of Sansevieria roxburghiana. International Journal of Current Pharmaceutical Research 3, $71-73$.

Philip, D., Kaleena, P.K., Valivittan, K., 2012. Antioxidant potential of Sansevieria roxburghiana Schult. and Schult. F. Asian Journal of Pharmaceutical and Clinical Research 5, 166-169.

Picerno, P., Autore, G., Marzocco, S., Meloni, M., Sanogo, R., Aquino, R.P., 2005. Antiinflammatory activity of verbinoside from Kigelia africana and evaluation of cutaneous irritation in cell cultures and reconstituted human epidermis. Journal of Natural Products $68,1610-1614$ 
Pillay, C.C.N., Jager, A.K., Mulholland, D.A., van Staden, J., 2001. Cyclooxygenase inhibiting and anti-bacterial activities of South African Erythrina species. Journal of Ethnopharmacology 74, 231-237.

Pittella, F., Dutra, R.C., Junior, D.D., Lopes, M.T.P., Barbosa, N.R., 2009. Antioxidant and cytotoxic activities of Centella asiatica (L) Urb. International Journal of Molecular Science 10, 3713-3721.

Pooley, E., 1993. The complete guide to trees of Natal, Zululand and Transkei, Natal Flora Publication Trust, p 240-245.

Pooley, E., 1998. A field guide to wild flowers of KwaZulu-Natal and the Eastern Region. Natal Flora Publications Trust, Durban.

Powell, E., 2001. Devil's claw, protective measures to ensure the sustainable use of Harpagophytum procumbens, one of South Africa's most valuable medicinal plants. Veld and Flora 87, 4:157.

Preetha, J.P., Karthika, K., 2009. Cosmeceuticals-An evolution. International Journal of Chemical and Technology Research 1, 1217-1223.

Pretorius, C., 2010. Antioxidant properties of Lippia javanica (Burm.f.) Spreng. M.Sc. Dissertation in Pharmaceutical Chemistry at the Potchefstroom Campus of the NorthWest University.

Pujol, J., 1990. Nature Africa: the herbalist handbook. Jean Pujol Natural Healers Foundation, Durban.

Rahman, M., Hossain, S., Rahaman, A., Fatima, N., Nahar, T., Uddin, B., Basunia, M.A., 2013. Antioxidant activity of Centella asiatica (Linn.) Urban: Impact of extraction solvent polarity. Journal of Pharmacognosy and Phytochemistry 1, 27-32.

Raimondo, D., Von Staden, L., Foden, W., Victor, J.E., Helm, N.A., Turner, R.C., Kamundi, D.A., Manyama, P.A., 2009. Red List of South African plants, Strelitzia 25, South African National Biodiversity Institute, Pretoria.

Ramoroka, R., Mapunya, T.G., 2006. Personal Communication. 
Rao, B.R., Kaul, P.N., Syamasundar, K.V., Ramesh, S., 2002. Water soluble fractions of rose-scented geranium (Pelargonium species) essential oil. Bioresource Technology 84, 243-246.

Reddy, C.V.K., Sreeramulu, D., Raghunath, M., 2010. Antioxidant activity of fresh and dry fruits commonly consumed in India. Food Research International 43, 285-288.

Retief, E., Herman, P.P.J., 1997. Plants of the northern provinces of South Africa: Keys and diagnostic characters. Strelitzia 6, National Botanical Institute, Pretoria.

Ribeiro, A., Romeiras, M.M., Tavares, J., Faria, M.T., 2010. Ethnobotanical survey in Canhane village, district of Massingir, Mozambique: medicinal plants and traditional knowledge. Journal of Ethnobiology and Ethnomedicine 6, 33.

Roberts, M., 1990. Indigenous healing plants. Southern Book Publishers, Halfway House, South Afirca.

Rupesh, T., Nitika, J., Raghvendra, P., Sardul, S., 2011. Practices in wound healing studies of plants. Evidence-Based complementary and Alternative medicine Article ID 438056.

Safayhi, H., Mack, T., Sabieraj, J., Anazodo, M.I., Subramanian, L.R., Ammon, H.P., 1992. Mechanism of anti-inflammatory actions of curcumine and boswellic acids. Journal of Pharmacology and Experimental Therapeutics 261, 1143-1146.

Saini, N.K., Singhal, M., 2012. Anti-inflammatory, analgesic and antipyretic activity of methanolic Tecomaria capensis leaves extract. Asian Pacific Journal of Tropical Biomedicine 2, 870-874.

Sandasi, M., Kamatou, G. P.P., Viljoen, A.M., 2011. Chemotaxonomic evidence suggests that Eriocephalus tenuifolius is the source of Cape chamomile oil and not Eriocephalus punctulatus. Biochemical Systematics and Ecology 39, 328-338.

Saral, Y., Uyar, B., Ayar, A., Nazirogly, M., 2002. Protective effects of topical alphatocopherol acetate on UVB irradiation in guinea pigs: importance of free radicals. Physiological Research 51, 285-290. 
Saraswathi, J., Venkatesh, K., Baburao, N., Hilal, M.H., Rani, A.R., 2011. Phytopharmacological importance of Pelargonium species. Journal of Medicinal Plants Research 5, $2587-2598$.

Sariri, R., Sabbaghzadeh, R., Poumohamad, F., 2011. In-vitro antioxidant and anti-tyrosinase activity of methanol extracts from Crocus sativus flowers. Pharmacologyonline 3, 1-11.

Sasidharan, S., Nilawatyi, R., Xavier, R., Latha, L.Y., Amala, R., 2010. Wound healing potential of Elaeis guineensis leaves in an infected albino rat model. Molecules 15, 31863199.

Sasidharan, S., Nilawatyi, R., Xavier, R., Latha, L.Y., Amala, R., 2012. Wound healing potential of Elaeis guineensis Jacq leaves in an infected albino rat model. Molecules 15, 3186-3199.

Savikin, K., Dobric, S., Tadic, V., Zdunic, G., 2007. Anti-inflammatory activity of ethanol extracts of Hypericum perforatum L., H. barbatum Jacq., H. hirsutum L., H. richeri Vill. and H. androsaemum L. in rats. Phytotherapy Research 21, 176-180.

Sawhney, S.S., Mir, M.A., Kumar, S., 2011. Phytochemical screening and antioxidant properties of Bauhinia variegata (bark). Journal of Pharmaceutical Science and Technology 3, 645-650.

Schmidt, E., Lotter, M., McCleland, W., 2002. Trees and shrubs of Mpumalanga and Kruger National Park. Jacana, Johannesburg.

Selvarani, V., Hudson, J.B., 2009. Multiple inflammatory and antiviral activities in Adansonia digitata (Baobab) leaves, fruits and seeds. Journal of Medicinal Plants Research 3, 576-582.

Sharma, R., Kishore, N., Hussein, A., Lall, N., 2014. The potential of Leucosidea sericea against Propionibacterium acnes. Phytochemistry Letters 7, 124-129.

Shivanand, P., Nilam, M., Viral, D., 2010. Herbs play an important role in the field of cosmetics. International Journal of PharmTech Research 2, 632-639. 
Silva, B.A., Ferreres, F., Malva, J.O., Dias, A.C.P., 2005. Phytochemical and antioxidant characterization of Hypericum perforatum alcoholic extracts. Food Chemistry 90, 157167.

Simelane, M.B.C., Lawal, O.A., Djarova, T.G., Opoku, A.R., 2010. In vitro antioxidant and cytotoxic activity of Gunnera perpensa L. (Gunneraceae) from South Africa. Journal of Medicinal Plants Research 4, 2181-2188.

Simpson, D., 1998. Buchu-South Africa's amazing herbal remedy. Scott. Med J 43, 189-191.

Singh, G., Sharma, P.K., Dudhe, R., Singh, S., 2010. Biological activities of Withania somnifera. Annals of Biological Research 1, 56-63.

Singh, R.P., Agarwal, R., 2009. Cosmeceuticals and Silibinin. Clinics in Dermatology 27, $479-484$.

Siramon, P., Ohtani, Y., 2007. Anti-oxidative and antiradical activities of Eucalyptus camaldulensis leaf oils from Thailand. Journal of Wood Science 53, 498-504.

Smith, A., 1895. A contribution to the South African material medica, Third ed. Lovedale, South Africa.

Smith, C.A., 1966. Common names of South African plants. Memoirs of the Botanical Survey of South Africa No. 35. Department of Agricultural Technical Services, Pretoria.

Srividya, A.R., Sumithra, G.S., 2010. Antioxidant, antimicrobial and cytotoxic property of Melianthus major leaves. Journal of Global Pharma Technology 2, 94-97.

Steenkamp, V., Mathivha, E., Gouws, M.C., van Rensburg, C.E.J., 2004. Studies on antibacterial, antioxidant and fibroblast growth stimulation of wound healing remedies from South Africa. Journal of Ethnopharmacology 95, 353-357.

Steyn, E.M.A., Robbertse, P.J., Van Wyk, A.E., 1987. Floral development in Greyia flanaganii with notes on inflorescence initiation and sympodial branching. South African Journal of Botany 53, 194-201.

Street, R.A., Prinsloo, G., 2013. Commercially important medicinal plants of South Africa: A review. Journal of Chemistry 2013, 1-16. 
Tahir, N.I., Shaari, K., Abas, F., Parveez, G.K.A., Ishak, Z., Ramli, U.S., 2012. Characterization of apigenin and luteolin derivatives from oil palm (Elaeis guineensis Jacq.) leaf using LC-ESI-MS/MS. Journal of Agriculture and Food Chemistry 60, 1120111210.

Tong, X., Zhang, H., Timmermann, B.N., 2011. Chlorinated withanolides from Withania somnifera. Phytochemistry Letters 4, 411-414.

Van der Lugt, J.J., Schultz, R.A., Fourie, N., Hon, L.J., Jordaan, P., Labuschagne, L., 1992. Galenia africana L. poisoning in sheep and goats: hepatic and cardiac changes. Journal of Veterinary Research 59, 323-333.

Van der Walt, J.J.A., 1977. Pelargoniums of Southern Africa. Purnell, Cape Town.

Van der Walt, J.J.A., Vorster, P.J., 1988. Pelargoniums of Southern Africa, Vol. 3. National Botanical Gardens: Cape Town.

Van Rooyen, G., Steyn, H., 1999. Cederberg, Clanwilliam and Bieudow Valley. South African Wild Flower Guide 10. Botanical Society of South Africa, Cape Town.

Van Wyk, B., Malan, S., 1988. Field guide to the wild flowers of Witwatersrand and Pretoria region. Struik, Cape Town.

Van Wyk, B., Smith, G., 1996. Guide to the aloes of South Africa. Briza Publications, Pretoria.

Van Wyk, B., Van Wyk, P., 1997. Field guide to trees of southern Africa. Struik, Cape Town.

Van Wyk, B., Van Wyk, P., Van Wyk, B.E., 2011. Photo guide to trees of Southern Africa. Briza, South Africa.

Van Wyk, B.E., 2008. A review of Khoi-San and Cape Dutch medical ethnobotany. Journal of Ethnopharmacology 119, 331-341.

Van Wyk, B.-E., De Wet, H., Van Heerden, F.R., 2008. An ethnobotanical survey of medicinal plants in south-eastern Karoo, South Africa. South African Journal of Botany 74, 696-704. 
Van Wyk, B.E., Gericke, N., 2000. People's plants, A guide to useful plants of Southern Africa. p. 218-219, Briza, Pretoria, South Africa.

Van Wyk, B.E., van Oudtshoom, B., Gericke, N., 2000. Medicinal plants of South Africa 2nd ed. Pretoria: Briza Publication; p. 146.

Van Wyk, B.E., Van Oudtshoorn, B., Gericke, N., 1997. Medicinal plants of South Africa. Briza Publications, Pretoria, South Africa.

Van Wyk, B.E., Van Oudtshoorn, B., Gericke, N., 2009. Medicinal plants of South Africa, Second edition, Briza Publications, Pretoria.

Van Wyk, B.-E., Viljoen, A., 2011. Special issue on Economic Botany, South African Journal of Botany 77, 809-1012.

Velioglu, Y.S., Mazza, G., Gao, L., Oomah, B.D., 1998. Antioxidant activity and total phenolics in selected fruits, vegetables, and grain products. Journal of Agricultural and Food Chemistry 46, 4113-4117.

Vermaak, I., Kamatou, G.P.P., Komane-Mofokeng, B., Viljoen, A.M., Beckett, K., 2011. African seed oils of commercial importance-Cosmetic applications. South African Journal of Botany 77, 920-933.

Von Koenen, E.M., 1996. Medicinal Poisonous and Edible Plants in Namibia. Klaus Hess, Windhoek and Gottingen.

Warra, A.A., 2012. Sesame (Sesamum Indicum L.) seed oil methods of extraction and its prospects in cosmetic industry: A review. Bayero Journal of Pure and Applied Sciences 4, 164-168.

Watt, J.M., 1935. The uses and actions of Xysmalobium undulatum R.Br. South African Journal of Medicine and Science I, September.

Watt, J.M., Breyer, B.M.G., 1962. The medicinal and poisonous plants of Southern and Eastern Africa, 2nd ed. Livingstone, London. 
Welford, L., Jara, M.E.A., Gericke. N., 2008. HerbalGram 79 includes articles on The Painted Desert: Tree of Life: The Use of Marula Oil in Southern Africa, American Botanical Council, HerbalGram 79, 32-41.

Wet, H., van Heerden, F.R., van Wyk, B.E., 2011. Alkaloidal variation in Cissampelos Capensis (Menispermaceae). Molecules 16, 3001-3009.

Wet, H.D., Nzama, V.N., Van Vuuren, S.F., 2012. Medicinal plants used for the treatment of sexually transmitted infections by lay people in northern Maputaland, KwaZulu-Natal Province, South Africa. South African Journal of Botany 78, 12-20.

WHO, 2012. http://www.who.int/violence_injury prevention/other_injury/burns/en/ Violence and injury prevention.

Yagi, A., Takeo, S., 2003. Anti-inflammatory constituents, aloesin and aloemannan in Aloe species and effects of tanshinon VI in Salvia miltiorrhiza on heart. Yakugaku Zasshi 123, $517-532$.

Yamakoshi, J., Otsuka, F., Sano, A., Tokutake, S., Saito, M., Kikuchi, M., Kubota, Y., 2003. Lightening effect on ultraviolet-induced pigmentation of guinea pig skin by oral administration of a Proanthocyanidin rich extract from grape seeds. Pigment Cell Research 16, 629-638.

Yativ, M., Harary, I., Wolf, S., 2010. Sucrose accumulation in watermelon fruits: Genetic variation and biochemical analysis. Journal of Plant Physiology 167, 589-596.

Yff, B.T.S., Lindsey, K.L., Taylor, M.B., Erasmus, D.G., Jager, A.K., 2002. The pharmacological screening of Pentanisia prunelloides and the isolation of the antibacterial compound palmitic acid. Journal of Ethnopharmacology 79, 101-107.

Zainol, M.K., Abd-Hamid, A., Yusof, S., Muse, R., 2003. Antioxidative activity and total phenolic compounds of leaf, root and petiole of four accessions of Centella asiatica (L.) Urban. Food Chemistry 81, 575-581. 
Zhang, H., Miao, H., Wang, L., Qu, L., Liu, H., Wang, Q., Yue, M., 2013. Genome sequencing of the important oilseed crop Sesamum indicum L. Genome Biology 14, 401-409.

Zimba, N., Wren, S., Stucki, A., 2005. Three major tree nut oils of southern central Africa: their uses and future as commercial base oils. International Journal of Aromatherapy 15, 177-182. 